UNIVERSIDADE DE SÃO PAULO

FACULDADE DE FILOSOFIA, LETRAS E CIÊNCIAS HUMANAS

DEPARTAMENTO DE LETRAS CLÁSSICAS E VERNÁCULAS

PROGRAMA DE FILOLOGIA E LÍNGUA PORTUGUESA

\title{
CIÊNCIA, DISCURSO E MÍDIA: A DIVULGAÇÃO CIENTÍFICA EM REVISTAS ESPECIALIZADAS
}

Solange de Sousa Santos

São Paulo

2007 
UNIVERSIDADE DE SÃO PAULO

FACULDADE DE FILOSOFIA, LETRAS E CIÊNCIAS HUMANAS

DEPARTAMENTO DE LETRAS CLÁSSICAS E VERNÁCULAS

PROGRAMA DE FILOLOGIA E LÍNGUA PORTUGUESA

\section{CIÊNCIA, DISCURSO E MÍDIA: A DIVULGAÇÃO CIENTÍFICA EM REVISTAS ESPECIALIZADAS}

Solange de Sousa Santos

Dissertação apresentada ao Programa de PósGraduação em Filologia e Língua Portuguesa, do Departamento de Letras Clássicas e Vernáculas da faculdade de Filosofia, Letras e Ciências Humanas da Universidade de São Paulo, para obtenção do título de Mestre em Filologia e Língua Portuguesa.

Orientadora: Prof $^{\mathrm{a}}$ Dr $^{\mathrm{a}}$ Sheila Vieira de Camargo Grillo

São Paulo

2007 
Dedico a Deus, por ter me concedido a graça de entrar no mestrado e por ter me dado forças para concluí-lo. 


\section{AGRADECIMENTOS}

Esse trabalho não seria o mesmo sem a ajuda e o apoio de muitas pessoas, e a elas faço aqui meus agradecimentos.

Agradeço com toda minha alma a minha orientadora $\operatorname{Prof}^{\mathrm{a}} \mathrm{Dr}^{\mathrm{a}}$ Sheila Vieira de Camargo Grillo por sua imensa disponibilidade, dedicação, interesse, encorajamento e diálogo. Sua supervisão nas inúmeras formulações e reformulações do texto é em grande parte responsável pelo que esse trabalho tiver de melhor, sendo somente minhas as falhas e deficiências.

Quero agradecer as os colegas do grupo de pesquisa: Ariadne, Alberto, Flávia, Rose e Simone, com os quais troquei impressões e dicas que me ajudaram a solucionar problemas dos mais diversos e pelo ambiente de camaradagem e apoio mútuo que compartilhamos.

Agradeço aos professores Sírio Possenti e Manuel Luiz Gonçalves Corrêa pelas sugestões valiosas dadas durante minha qualificação.

Aos meus pais, pelo estímulo e apoio incondicional desde a primeira hora, pela paciência e grande amizade com que sempre me ouviram, e sensatez com que sempre me ajudaram.

Aos meus irmãos, Simone e Osvaldo, pela paciência que tiveram comigo e pelo apoio que sempre me deram.

À Prof ${ }^{\mathrm{a}} \mathrm{Dr}^{\mathrm{a}}$ Maria do Rosário V. Gregolin, que durante a graduação me orientou e estimulou a seguir o caminho acadêmico.

Aos amigos que compartilharam comigo os prazeres e as dores da vida acadêmica, em especial Mariana e Anne amigas que tornaram minha vida menos dura e mais feliz.

Ao Roberto pela compreensão e pelo estímulo para que eu seguisse em frente, mesmo quando eu achei que não conseguiria.

À Faculdade de Filosofia Letras e Ciências Humanas (Departamento de Letras Clássicas e Vernáculas) da USP, nas pessoas dos seus docentes e funcionários, pelo acolhimento caloroso e continuada cooperação. 
Agradeço também, à Secretaria de Estado da Educação do Estado de São Paulo, pela bolsa concedida.

Em meio a tantos nomes e situações, é possível e até mesmo provável que eu tenha inadvertidamente negligenciado os agradecimentos a uma ou outra pessoa. A estes, minhas humildes e sinceras desculpas.

São Paulo, maio de 2007 Solange de Sousa Santos 


\section{RESUMO}

Temas relacionados à ciência e à tecnologia passaram a ocupar espaço cada vez maior na imprensa voltada para o homem comum. A crescente importância políticas dos temas ligados à ciência - saúde publica, manipulação genética, novas técnicas médicas etc. - reflete-se na cobertura regular da imprensa, em qualquer de suas formas de comunicação. O crescente interesse por parte de não especialistas em conhecimento científico provocou 0 surgimento de periódicos especializados em divulgação científica, dirigidos ao público em geral.

Filiando-se teoricamente à análise do discurso de linha francesa (sobretudo nos trabalhos de Maingueneau), este trabalho tem por objetivo analisar o discurso de divulgação científica submetido a diferentes coerções buscando levantar as particularidades textuais e discursivas constitutivas dos diferentes textos analisados (veículo de divulgação, enunciadores envolvidos, gênero, condições de produção, etc).

Para a análise foram selecionados textos de dois temas, "clonagem humana" e "vacinas", publicados nas revistas Superinteressante, da editora abril, Galileu, da editora globo, Pesquisa FAPESP, de responsabilidade da Fundação de Ampara à Pesquisa do Estado de São Paulo (FAPESP), Ciência Hoje, uma publicação da Sociedade Brasileira para o Progresso da Ciência, e a Scientific American Brasil, da duetto editorial.

PALAVRAS-CHAVE: Discurso, Mídia, Ciência, Divulgação Científica e Gênero 


\begin{abstract}
Related subjects to the science and to the technology passed to occupy space every time larger in the directed press to the common man. The themes increasing political importance tied to science - health publishes, genetics manipulation, new medical techniques etc. - it reflects in the press regular coverage, in any of their communication forms. The increasing interest by not specialist in scientific knowledge provoked the specialized periodicals appearance in scientific divulgement, directed to the public in general.

Affiliating theoretically to the Discourse Analysis of French line (based in Maingueneau's jobs), this work has for goal analyze the scientific divulgement discourse submitted to the different coercions. For the analysis were going selected texts of two themes, "human cloning" and "vaccines", published in the cover Superinteressante, of the press Abril, Galileu, of the press globo, Pesquisa FAPESP, of responsibility of Fundação de Amaparo à Pesquisa do Estado de São Paulo (FAPESP), Ciência Hoje, a publication of Brazilian Society for the Science Progress, and Scientific American Brasil, of duetto editorial.
\end{abstract}

KEY-WORDS: Discourse, Media, Science, Scientific Divulgement and Gender 


\section{SUMÁRIO}

INTRODUÇÃO

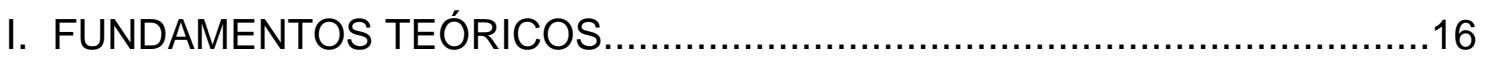

1.1 Análise do Discurso: breve histórico de um campo teórico ..............16

1.2 Heterogeneidade: observações no campo do discurso relatado.......22

1.2.1 As formas do discurso relatado (DR).............................25

1.2.2 Discurso direto (DD) $\times$ Discurso indireto (DI) ...................27

1.2.3 Discurso direto livre (DDL) e discurso indireto livre (DIL)..29

1.3 A problemática do gênero do discurso...............................................30

1.3.1 Maingueneau e os gêneros de discurso...............................32

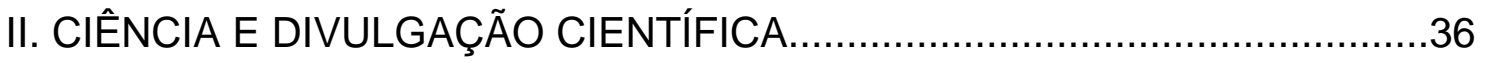

2.1 Uma reflexão sobre o campo científico..........................................36

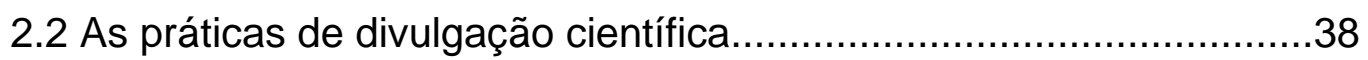

2.2.1 Divulgação científica $\times$ Disseminação científica $\times$ Jornalismo científica 39

2.2.2 O funcionamento textual discursivo da divulgação científica

2.2.2.1 Authier-Revuz e a DC..........................................40

2.2.2.2 Zamboni e a DC.................................................42

2.3 Caminhos da divulgação científica no Brasil...................................44

III. GÊNERO DE DISCURSO: A CONSTITUIÇÃO DOS SENTIDOS EM TEXTOS DE DIVULGAÇÃO CIENTÍFICA.................................................50

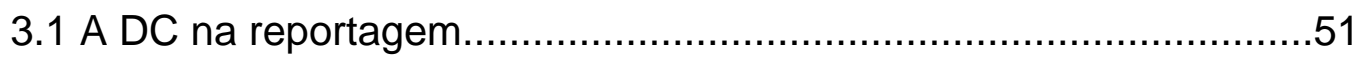

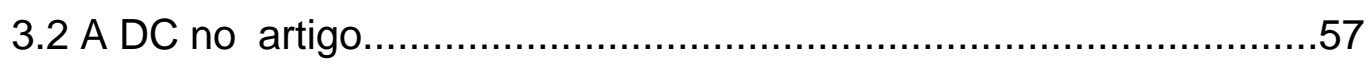

IV. DIVULGAÇÃO CIENTÍFICA: AS RELAÇÕES ENTRE ENUNCIADOR E CO-

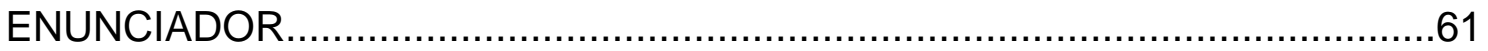

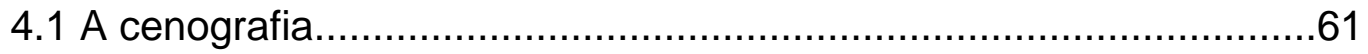




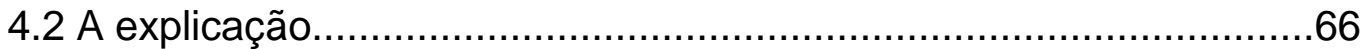

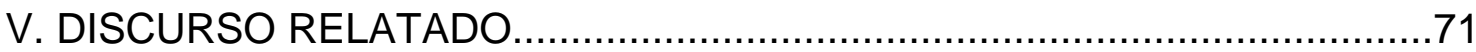

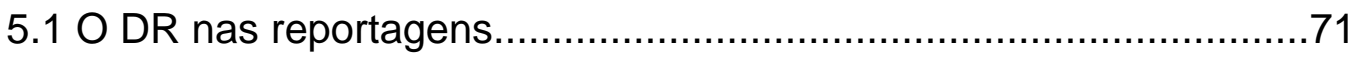

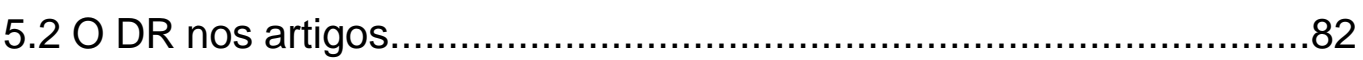

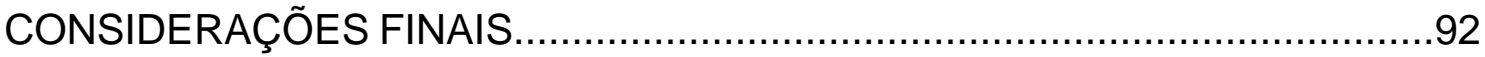

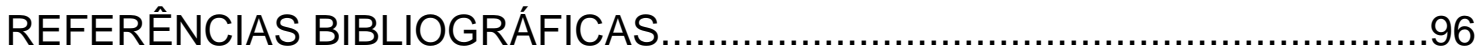




\section{INTRODUÇÃO}

A sociedade contemporânea goza de uma posição privilegiada no que se refere às possibilidades de apropriação de saberes socialmente constituídos e valorizados. Muitos desses saberes, que boa parte da sociedade desfruta hoje, se devem principalmente às fontes de divulgação, que ganharam extensão à medida que deixaram de se restringir a uma população de leitores circunscrita aos especialistas e bem formados e passaram a circular em meio a um público geral.

A extensão da literatura de divulgação levou ao surgimento de uma classe de "jornalistas científicos" responsável pela popularização da idéia de ciência no conjunto da população, mas eles não são os únicos responsáveis pela divulgação de saberes científicos, existe um grande número de cientistas que também assumem o papel de divulgador, seja do seu próprio trabalho, seja do trabalho de outros cientistas.

A Associação Brasileira de Jornalismo Científico (ABJC) criada por José Reis, morto em 2002, é uma entidade importante no que se refere à divulgação científica no Brasil. Uma das tarefas da entidade é a realização de congressos nacionais, o último (o sexto), realizado em Florianópolis, homenageou José Reis, considerado o 'pai do jornalismo científico'.

Para a análise de divulgação científica selecionamos um corpus constituído de textos publicados em revistas especializadas. Descrevemos a seguir o percurso seguido na seleção do corpus da dissertação.

\section{Arquivo e corpus}

Antes de descrevermos o material de análise selecionado, apresentamos algumas noções teóricas sobre corpus.

Pêcheux (1990) coloca a noção de arquivo em oposição à noção de corpus experimental, o qual é constituído por produções em situação de testes, elaboradas pelo analista (questionários, entrevistas etc.). Já arquivo é formado por enunciados preexistentes à pesquisa e que são tomados como objetos de estudo, tais como os corpora empregados pelos historiadores.

Maingueneau (1991) utiliza a noção de arquivo para se referir a um conjunto de enunciados tomados em uma relação de filiação a enunciados 
anteriores e que definem uma memória e um lugar de enunciação. Já a noção de corpus corresponde a um recorte efetuado pelo analista na superfície discursiva, o qual elabora uma seleção de formas, vistas como capazes de revelar o modo de delimitação de uma formação discursiva. Maingueneau (1991, p.15) utiliza a noção de corpus enquanto constituída de diferentes níveis:

O corpus máximo: depende da variável que permite agrupar os enunciados: por exemplo, todos os enunciados que pertencem a um gênero do discurso determinado ou são produzidos a partir de tal posição ideológica. A maior parte do tempo esse corpus máximo não é delimitável.

O corpus delimitado: sobre o corpus máximo, o analista circunscreve um conjunto de enunciados, em função do objetivo de sua pesquisa.

O corpus elaborado: a partir das hipóteses de trabalho que ele constrói, o pesquisador define um programa de análise e deve extrair do corpus delimitado um ou vários corpora elaborados (certos episódios narrativos, enunciados de tal estrutura sintática, um conjunto de passagens organizadas em torno de um conector argumentativo etc.).

Para a composição do corpus máximo desta pesquisa ${ }^{1}$ foram selecionadas cinco publicações na área de DC do mercado editorial brasileiro. São elas: Ciência Hoje, publicação de responsabilidade da Sociedade Brasileira para o Progresso da Ciência, a Revista Pesquisa FAPESP, de responsabilidade da Fundação de Amparo à Pesquisa do Estado de São Paulo, a Galileu, da editora Globo, a Superinteressante, da editora Abril e a Scientific American Brasil, da Duetto editorial.

A escolha das cinco publicações é justificável pelo fato de serem representativas do que se tem produzido em divulgação científica (DC) no Brasil, visto que o objetivo geral desse trabalho é verificar o funcionamento do discurso de DC submetidos a diferentes condições de produção.

Em seguida, o corpus delimitado foi construído com base no critério temático, ou seja, foram selecionados textos com temas tratados nas cinco revistas, no período de 1999-2004. A seleção dos temas baseou-se no fato de serem abordados nas cinco publicações. A escolha temática justifica-se pelo objetivo proposto de analisar o tratamento discursivo dado ao mesmo tema em

\footnotetext{
1 Esta dissertação integra-se ao projeto “A circulação do conhecimento na divulgação científica” (CNPq 401573/2004-4), coordenado pela Profa. Dra. Sheila Vieira de Camargo Grillo. O foco principal do projeto é a descrição e a interpretação de procedimentos discursivos de transmissão de saberes científicos ao público de não-especialistas, presentes em diferentes gêneros e esferas.
} 
diferentes veículos, ou seja, em editoras pertencentes a campos distintos: campo do jornalismo comercial e o campo científico

Os temas selecionados encontram-se na tabela a seguir:

\begin{tabular}{|c|c|c|}
\hline REVISTAS & CLONAGEM & VACINAS \\
\hline GALILEU & $\begin{array}{l}\text { A um passo da clonagem } \\
\text { humana. } \\
\qquad 10 / 2001\end{array}$ & $\begin{array}{l}\text { AIDS imunes por natureza, } \\
\text { pessoas que vencem o HIV } \\
\text { sem auxilio de remédios } \\
\text { ajudam cientistas na busca da } \\
\text { vacina. } \\
09 / 2003\end{array}$ \\
\hline CIÉNCIA HOJE & $\begin{array}{l}\text { A técnica de clonagem de } \\
\text { mamíferos. } \\
10 / 2001\end{array}$ & $\begin{array}{l}\text { Vacina genética contra } \\
\text { tuberculose. } \\
10 / 1999\end{array}$ \\
\hline SUPERINTERESSANTE & $\begin{array}{c}\text { Homens em Série } \\
07 / 2001\end{array}$ & $\begin{array}{c}\text { Vacinas fazem bem ou mal? } \\
02 / 2001\end{array}$ \\
\hline PESQUISA FAPESP & $\begin{array}{l}\text { Lei polêmica projeto restringe } \\
\text { poder da CTNBio, proíbe } \\
\text { clonagem terapêutica } \\
\text { mobiliza cientistas. } \\
\text { 03/2004 }\end{array}$ & $\begin{array}{l}\text { O alvo é a saúde humana, } \\
\text { começam os primeiros testes } \\
\text { em seres humanos da vacina } \\
\text { gênica desenvolvida no Brasil... } \\
11 / 2002\end{array}$ \\
\hline $\begin{array}{l}\text { SCIENTIFIC AMERICAN } \\
\text { BRASIL }\end{array}$ & $\begin{array}{c}\text { Prós e contras da clonagem } \\
\text { humana. } \\
07 / 2003\end{array}$ & $\begin{array}{c}\text { AIDS, a grande batalha da } \\
\text { vacina. } \\
09 / 2002\end{array}$ \\
\hline
\end{tabular}

E por fim, no que se refere ao corpus elaborado, o exame do corpus gira em torno de algumas proposições:

$\left.1^{\circ}\right)$ Nos periódicos de divulgação científica do campo do jornalismo comercial (Galileu, Superinteressante e Scientific), as reportagens têm valor de mercadoria e, como tal, precisam vender-se lançando mão de várias estratégias para atrair o leitor: fragmentação, ilustrações, fotos, boxes explicativos, assumindo o discurso da notícia. No entanto, a Scientific American Brasil , também ligada ao campo do jornalismo comercial, apresenta uma particularidade, traz artigos assinados por especialistas.

$2^{\circ}$ ) Nos periódicos ligados a organismos de fomento à pesquisa no Brasil (Ciência Hoje, Pesquisa Fapesp) podemos ressaltar dois pontos: primeiro, na Ciência Hoje,embora também encontremos artigos assinados por jornalistas, a maioria dos textos é escrita por cientistas que divulgam seu próprio trabalho ou 
trabalho de outros cientistas; segundo, na Pesquisa FAPESP, os textos são assinados por jornalistas como nos periódicos do jornalismo comercial.

3ํ) O divulgador escreve sobre ciência para "alguém", esse "alguém" é o leitor leigo em matéria de ciência que o sujeito enunciador deve ter em mente ao produzir um enunciado. Nossa hipótese inicial é de que os leitores das revistas ligadas ao campo do jornalismo comercial é distinto daqueles leitores das revistas pertencentes ao campo científico, e por isso, visando um leitor específico, o funcionamento discursivo dos textos são distintos.

\section{Perspectiva teórica e perguntas de pesquisa}

Os textos serão analisados sob a ótica da análise do discurso de linha francesa, principalmente a praticada por Maingueneau, buscando levantar as particularidades textuais e discursivas constitutivas do discurso de divulgação científica, dando especial atenção a três aspectos principais na constituição dos efeitos de sentido os textos de divulgação científica: o gênero, as relações entre enunciador e co-enunciador e o discurso relatado. As perguntas que conduziram inicialmente meu olhar no exame do corpus giram basicamente em torno de três questões:

I. Existem diferenças no funcionamento do discurso de divulgação científica em revistas ligadas ao campo do jornalismo comercial e as associadas ao campo científico? Qual a relação entre esses campos e os gêneros do discurso?

II. Que tipo de leitor cada uma das publicações procura atingir e de que modo elas fazem isso?

III. De que modo é estruturado o discurso relatado nos textos, ou seja, qual a relação entre as fontes, os campos e os gêneros estudados?

No que se refere à primeira questão, o aumento dos estudos sobre gênero do discurso aponta para a relevância de levá-lo em consideração sempre que se analisam os efeitos de sentido nos textos. A DC é uma prática 
discursiva que circula em uma grande variedade de gêneros (temos a DC em artigos, reportagens, perguntas/respostas, obras literárias, panfletos, etc). Em cada gênero que assume se estrutura de modo específico, sofrendo coerções, tais como:

a. econômica - textos-mercadoria nas editorias comerciais;

b. público-alvo: cientistas sobretudo na Pesquisa FAPESP e $\mathrm{CH}$ e público amplo na Galileu e Superinteressante e Scientific American Brasil;

c. finalidade: compromisso com a defesa do campo científico e das pesquisas da instituição (Pesquisa FAPESP/Ciência Hoje), apresentar críticas decorrentes da externalidade ao campo científico (Galileu/Superinteressante) tanto do gênero quanto do campo a ele associado. Nesse sentido, é importante levar em conta questões relativas ao gênero na análise dos textos de DC.

A segunda questão exige uma análise das relações enunciador/leitor (co-enunciador). Os enunciados são produzidos tendo em vista atingir um determinado público e para isso o enunciador vale-se do que chamamos cenografia ${ }^{2}$. A cenografia pode ser usada como instrumento de captação de um determinado leitor, é importante ressaltar que o leitor objeto deste trabalho não é um leitor virtual ou empírico, mas sim aquele inscrito no enunciado.

Por fim, a terceira questão, nos remete ao discurso relatado (DR) $O$ nosso corpus é composto por textos de DC publicados em revistas especializadas, ou seja, está diretamente relacionado com a mídia impressa e com o jornalismo científico. Desse modo, a exposição do funcionamento do discurso relatado nos textos mostrou-se importante, uma vez que o campo jornalístico faz grande uso do DR (principalmente do discurso direto) na construção dos efeitos de verdade e credibilidade das informações publicadas.

Esta dissertação é composta por cinco capítulos. O primeiro capítulo apresenta os fundamentos da Análise de Discurso francesa fazendo um apanhado histórico, apresenta também os fundamentos teóricos no qual o meu

\footnotetext{
${ }^{2}$ O termo cenografia vem de Maingueneau, para ele " cenografia não deve ser concebida como um quadro preestabelecido mas como um processo de círculo paradoxal na qual a enunciação, por sua própria maneira de desdobrar seus conteúdos, deve legitimar a situação de enunciação que a torna possível (enunciador, co-enunciador, momento e lugar).” (Maingueneau, 2000, p.21).
} 
trabalho está embasado. O segundo capítulo é sobre ciência e divulgação científica, aqui é feita uma exposição de alguns trabalhos na área e esclarecemos o que entendemos por divulgação científica. No capítulo terceiro, seguindo as concepções de Maingueneau, tratamos das questões relativas ao gênero do discurso, expondo as coerções que constituem os efeitos de sentido no gênero reportagem e no gênero artigo. No capítulo seguinte, dedicamo-nos às relações estabelecidas entre o enunciador e o co-enunciador, observando a cenografia e os vários tipos de leitores inscritos nos textos. No quinto capítulo, expomos o funcionamento do discurso relatado nos textos de divulgação científica de diferentes gêneros e os sentidos por ele produzidos. Seguem-se as considerações finais e as referências bibliográficas. 


\section{Cap. I}

\section{FUNDAMENTOS TEÓRICOS}

Neste capítulo temos por objetivo assentar nossas discussões acerca de algumas questões teóricas importantes na fundamentação desta pesquisa. Iniciaremos fazendo um percurso pela história da Análise de Discurso francesa. De acordo com Gregolin (2004), o retorno à história epistemológica da AD é necessário para compreendermos certas determinações que marcam a maneira de nos colocarmos no interior desse campo, ou seja, esclarece em que medida nosso trabalho pode reivindicar uma filiação com a AD francesa.

A recuperação da historicidade dos conceitos pode levar-nos a esclarecer a ambigüidade do próprio rótulo "análise do discurso de linha francesa". Em um primeiro momento, esse tipo de retomada pode parecer desnecessário, visto que a AD no Brasil já possui bases bastante sólidas, no entanto, esse exercício de recuperação da historicidade se faz importante tendo em vista os leitores presumidos deste trabalho, leitor que não necessariamente conhece a história da disciplina e as sua teses de base. Em um segundo momento, trataremos de questões relativas à heterogeneidade, visto que o discurso relatado é um fator importante na constituição dos efeitos de sentido nos textos de divulgação científica. Por fim, apoiados na concepção de Dominique Maingueneau, fazemos uma discussão sobre a problemática dos gêneros do discurso. A questão dos gêneros tornou-se importante neste trabalho, em razão de o nosso corpus ser composto por textos de gêneros distintos e, por isso, significarem de maneiras diferentes.

\subsection{Análise do Discurso: breve histórico de um campo teórico}

De acordo com Brandão (1995 p.15)

"Foram os formalistas russos que abriram espaço para a entrada no campo dos estudos lingüísticos daquilo que se chamaria mais tarde discurso. Operando com o texto e nele buscando uma lógica de encadeamento "transfrásticos", superam a abordagem filológica ou impressionista que até então dominava os estudos da língua. Essa abertura em direção ao discurso não chega, entretanto, às últimas conseqüências, pois seus seguidores, os estruturalistas, propõem-se como objetivo estudar a estrutura do texto nele mesmo e por ele 
mesmo e restringem-se a uma abordagem imanente do texto, excluindo qualquer reflexão sobre sua exterioridade."

Os anos 50 serão decisivos para a constituição de uma análise do discurso, graças aos trabalhos, de um lado, de Harris (Discourse Analysis, 1952 apud Brandão, 1995) que mostra a possibilidade de ultrapassar as análises confinadas à frase e, de outro lado, os trabalhos de R. Jakobson e E. Benveniste sobre a enunciação. Aplicando os procedimentos da lingüística distribucional americana aos enunciados, Harris defende uma nova forma de estudar o texto, em que se faz necessário entender como o texto diz alguma coisa e não determinar o que ele diz. Embora a obra de Harris possa ser considerada o marco inicial da análise do discurso, ela se coloca ainda como simples extensão da lingüística na medida em que transfere e aplica procedimentos de análise de unidades da língua aos enunciados e situa-se fora de qualquer reflexão sobre a significação e as considerações sócio-históricas de produção que vão distinguir e marcar posteriormente a análise do discurso.

Numa direção diferente, Benveniste dá relevo ao papel do sujeito falante no processo da enunciação e procura mostrar como acontece a inscrição desse sujeito nos enunciados que emite. Ao ato individual de se apropriar de uma língua e, por intermédio de um ato individual de utilização, colocá-la em funcionamento, chamou-se enunciação, onde se detectam os caracteres formais da própria língua que evidenciam a inscrição no enunciado do evento enunciativo.

Uma preocupação sempre norteou esse teórico: a de estabelecer uma relação entre o que é característico da língua e o que é característico do discurso. Neste último, a discussão vai ser implícita, uma vez que lidará com entidades vinculadas a ele, e não com sua discussão específica. Essas entidades (enunciação e enunciado) estão naquelas relações que Benveniste estabeleceu entre pessoa e não-pessoa; as pessoas verbais eu/tu (pessoa do enunciado verbal) e ele (considerado como não-pessoa).

Segundo Orlandi (1986), essas duas direções vão marcar duas maneiras diferentes de pensar a teoria do discurso: uma que a entende como uma extensão da lingüística (que corresponderia à perspectiva americana) e outra que considera a relação necessária entre o dizer e as condições de produção 
desse dizer, colocando a exterioridade como marca fundamental (que corresponderia à perspectiva européia). Esse pressuposto exige um deslocamento teórico, de caráter conflituoso, que vai recorrer a conceitos exteriores ao domínio de uma lingüística imanente para dar conta de análise de unidades mais complexas da linguagem.

A chamada Escola francesa de Análise do Discurso filia-se, segundo Maingueneau (1997), a uma certa tradição intelectual européia (sobretudo da França), acostumada a unir reflexão sobre o texto e sobre a história. Nasceu tendo como base a interdisciplinaridade, pois ela era preocupação não só de lingüistas como de historiadores e de alguns psicólogos. Filia-se também a uma certa prática escolar que é da "explicação do texto" muito em voga na França, do colégio à universidade, nos idos anteriores a 1960. Originária da necessidade de superar o quadro teórico de uma lingüística frasal que não dava conta do texto em toda sua complexidade, a análise de discurso francesa - estruturada por Michel Pêcheux e outros a partir do final da década de sessenta na França - volta-se para o exterior lingüístico, procurando apreender como no lingüístico inscrevem-se as condições sócio-históricas de produção.

A linguagem, sob a perspectiva da Análise do Discurso, passa a ser um fenômeno que deve ser estudado não só em relação ao seu sistema interno, enquanto formação lingüística a exigir de seus usuários uma competência específica, mas também enquanto formação ideológica, que se manifesta através de uma competência sócio-ideológica. $O$ discurso é uma das instâncias em que a materialidade ideológica se concretiza, isto é, é um dos aspectos materiais da "existência material" das ideologias. Ao analisarmos a articulação da ideologia com o discurso, dois conceitos já tradicionais em AD devem ser colocados: o de formação ideológica (FI) e o de formação discursiva (FD).

Para Pêcheux (1988), a região do materialismo histórico que interessa a uma teoria do discurso é o da superestrutura ideológica ligada ao modo de produção dominante na formação social considerada. Dessa forma, é uma materialidade específica articulada sobre a materialidade econômica que deve caracterizar a ideologia.

$\mathrm{Na}$ reprodução das relações de produção, uma das formas pela qual a instância ideológica funciona é a da "interpelação ou assujeitamento do sujeito 
como sujeito ideológico". Essa interpelação ideológica consiste em fazer com que cada indivíduo (sem que ele tome consciência disso, mas, ao contrário, tenha a impressão de que é o senhor de sua própria vontade) seja levado a ocupar seu lugar em um dos grupos ou classes de uma determinada formação social. As classes sociais, assim constituídas, mantêm relações que são reproduzidas continuamente e garantidas materialmente pelo que Althusser (1974) denominou AIE. Num determinado momento histórico e no interior mesmo desses aparelhos, as relações de classe podem se caracterizar pelo afrontamento de posições políticas e ideológicas que se organizam de forma a entreter entre si relações de aliança, de antagonismo ou de dominação. Essa organização de posições políticas e ideológicas é que constitui as formações ideológicas.

Constituindo o discurso um dos aspectos materiais de ideologia, pode-se afirmar que o discurso é uma espécie pertencente ao gênero ideológico. Em outros termos, a formação ideológica tem necessariamente um de seus componentes uma ou várias formações discursivas interligadas, isso significa que os discursos são governados por formações ideológicas.

Concebida por Foucault (1971) ao interrogar-se sobre as condições históricas e discursivas nas quais se constituem os sistemas de saber e, depois, elaborada por Pêcheux, a noção de FD representa na AD um lugar central da articulação entre língua e discurso.

Formalmente, a noção de FD envolve dois tipos de funcionamento:

a) a paráfrase: uma FD é constituída por um sistema de paráfrase, isto é, é um espaço em que enunciados são retomados e reformulados num esforço constante de fechamento de suas fronteiras em busca da preservação da sua identidade. A essa noção, Orlandi (1984) contrapõe uma outra: a de polissemia, atribuindo a esses conceitos opositivos 0 papel de mecanismos básicos do funcionamento discursivo. Enquanto a paráfrase é um mecanismo de "fechamento", de "delimitação" das fronteiras de uma formação discursiva, a polissemia rompe essas fronteiras, "embaralhando' os limites entre diferentes formações discursivas, instalando a pluralidade, a multiplicidade de sentidos; 
b) o pré-construído: constitui, segundo Pêcheux (1988), um dos pontos fundamentais da articulação da teoria dos discursos com a lingüística. $O$ termo designa aquilo que remete a uma construção anterior e exterior, independente, por oposição ao que é "construído" pelo enunciado. É o elemento que irrompe na superfície discursiva como se estivesse já aí. O pré-construído corresponde ao "toujours dejà-lá" da interpelação ideológica que não só fornece, mas impõe à "realidade" o seu "sentido" sob a forma da universalidade;

O conceito de FD regula, dessa forma, a referência à interpelaçãoassujeitamento do indivíduo em sujeito de seu discurso. É a FD que permite dar conta do fato de que sujeitos falantes, situados numa determinada conjuntura histórica, possam concordar ou não sobre o sentido a dar às palavras. Uma FD determina seus falantes "o que deve e pode ser dito" buscando uma homogeneidade discursiva, e os efeitos das contradições ideológicas de classe são recuperáveis no interior mesmo da unidade dos conjuntos de discurso.

Cabe à $A D$ trabalhar seu objeto (o discurso) inscrevendo-o na relação da língua com a história, buscando na materialidade lingüística as marcas das contradições ideológicas. Foucault (1971) vê uma FD como um "espaço de dissensões múltiplas" em que atuam oposições cujos níveis e papéis devem ser descritos não com o objetivo de nivelá-las ou pacificá-las em formas gerais de pensamento, mas de demarcar o ponto em que elas se constituem, de definir a forma que assumem, as relações que têm entre si e o domínio que elas comandam.

Preconizando, assim, um quadro teórico que alia o lingüístico ao sóciohistórico, na Análise do Discurso, dois conceitos tornaram-se nucleares: o de ideologia e o de discurso. $O$ núcleo das pesquisas em Análise do discurso (doravante $A D$ ) foi, nesse primeiro momento, o discurso político, efetuado por lingüistas e historiadores, com uma metodologia que associava a lingüística estrutural e uma teoria da ideologia, inspirada, ao mesmo tempo, na releitura da obra de Marx por Althusser e na psicanálise de Lacan.

Denunciando a ilusão que tem o Sujeito do discurso de estar na "origem do sentido", a Escola francesa privilegiava os procedimentos "analíticos", que desestruturavam o texto: Tratava-se de fazer 
aparecer o discurso como uma plenitude enganosa, cuja análise devia revelar a "inconsistência" fundamental, relacionando-o ao trabalho de forças inconscientes. (Maingueneau, 2000, p. 70)

No início dos anos 80, essa corrente teve suas bases teóricas desestruturadas. Pêcheux, autor mais representativo dessa corrente, escreveu, em 1983, um trabalho intitulado Análise de Discurso: três épocas, publicado em 1990. Nesse trabalho, o autor distingue três épocas na história da Análise do Discurso. A primeira época (AD-1), estruturalista, concebe o discurso como uma máquina autodeterminada e fechada, que assujeita seus enunciadores e se desenvolve baseada numa língua supostamente estável e homogênea. Constitui-se corpus fechado analisado lingüisticamente. A segunda época (AD2) faz das relações entre formações discursivas, objeto essencial da AD. O discurso é o espaço onde se ligam elementos "pré-construídos" elaborados em outros discursos. Mas, como na fase anterior, é mantida a idéia de sujeito homogêneo e assujeitado à estrutura. A terceira época (AD-3) marca a irrupção da problemática da heterogeneidade e da enunciação. A noção de heterogeneidade começa a fazer explodir a noção de máquina estrutural fechada. "Uma formação discursiva não é um espaço estrutural fechado, pois é constitutivamente 'invadida' por elementos que vêm de outro lugar (isto é, de outras formações discursivas) que se repetem nela, fornecendo-lhes suas evidências discursivas fundamentais" (Pêcheux, 1983/1990, p. 314).

No campo da noção de subjetividade, a tendência a reconhecer a heterogeneidade provoca uma revitalização do par Eu-Tu, que vai apresentar, como conseqüência, o Outro constitutivo da enunciação. Pode-se observar, de maneira evidente, a manifestação dessa heterogeneidade na própria superfície discursiva através da materialidade lingüística do texto, de formas marcadas que vão das mais explícitas (citações, por exemplo) às mais implícitas (alusões, por exemplo).

Atualmente os estudos discursivos passam por um momento bastante heterogêneo. Não há um acesso único ao discurso, mas uma multiplicidade de abordagens governadas por preocupações variadas. Segundo Maingueneau (1995b), esse fenômeno está ligado a uma globalização das trocas científicas, a uma concorrência generalizada no qual cada um vê-se obrigado a marcar sua diferença. Essa dispersão dos modos de abordagem é inseparável da 
abertura de campos de investigação: qualquer produção verbal pode tornar-se objeto de uma pesquisa.

Existe uma tensão permanente entre os recortes disciplinares e as pesquisas sobre discursividade que não somente são compartilhadas entre múltiplas correntes, mas ainda são colocadas no cruzamento de diversas disciplinas. De acordo com Maingueneau (1995b), as mesmas pesquisas têm um estatuto diferente à medida que as inserimos em títulos diversos dentro do campo da sociologia, antropologia, lingüística e da psicologia social. Essa instabilidade é resultado do próprio estatuto do discurso "ele designa menos um domínio empírico que um certo modo de apreensão da linguagem" (Maingueneau, 1995b, p. 06)

Em síntese, nos termos de Maingueneau (2000, p. 71), podemos falar em Escola Francesa, num sentido amplo, como um conjunto de pesquisas em análise do discurso que, sem pertencer a uma mesma escola, compartilham de algumas características: estudam, preferencialmente, corpora escritos, formações discursivas que apresentam um interesse histórico; refletem sobre a inscrição do Sujeito no seu discurso; fazem uso das teorias da enunciação lingüísticas; atribuem um papel privilegiado ao interdiscurso.

\subsection{Heterogeneidade: observações no campo do discurso relatado}

A linguagem não é evidência, transparência de sentidos produzida por um sujeito homogêneo. No discurso, o sujeito divide o espaço com o outro. Dentre os fatores de heterogeneidade, deve-se atribuir um papel privilegiado à presença de discursos "outros" num discurso. Sobre esse ponto, Authier-Revuz (1990) introduziu uma distinção amplamente utilizada entre heterogeneidade mostrada e heterogeneidade constitutiva, que Maingueneau (1997, p. 75) distingue da seguinte maneira: "a primeira incide sobre as manifestações explícitas, recuperáveis a partir de uma diversidade de fontes de enunciação, enquanto a segunda aborda uma heterogeneidade que não é marcada em superfície, mas que a $A D$ pode definir, formulando hipóteses, através do interdiscurso, a propósito da constituição de uma formação discursiva". Nesta seção, desenvolveremos a noção de discurso relatado tendo por base os trabalhos de Authier-Revuz (2001). 
Segundo a autora, ainda é freqüente nas gramáticas, o campo do discurso relatado ser limitadamente exposto de três formas: o discurso direto (DD), o indireto (DI) e o indireto livre (DIL), apresentados como uma espécie de progressão:

\begin{abstract}
O DD, tido como de funcionamento "simples" no plano sintático, e "fiel" e "objetivo" no plano semântico-enunciativo. O DI, tido como forma subordinada do primeiro, ou seja, como uma variante morfossintática, "derivável" a partir do DD por "regras" de transformação das pessoas e dos tempos. O DIL, tido como um indireto suavizado pela supressão do termo subordinante, ou uma mistura de DI e DD. (Authier-Revuz, 2001, p. 134).
\end{abstract}

Authier-Revuz (2001) esclarece que essas afirmações não são adequadas. O DD não é simples, ele seria, na verdade, bem mais complexo que o DI. O DD não é "objetivo" nem "fiel”, mesmo quando cita textualmente, ele não restitui o ato de enunciação na sua íntegra. O DI não é um DD subordinado "nenhuma derivabilidade de ordem morfossintática, isto é, derivadas de regras gramaticais, liga-os; eles derivam de duas operações radicalmente distintas referentes ao discurso outro que é relatado; a citaçãorelíquia (DD) e a reformulação-tradução (DI)" (Authier-Revuz, 2001, p. 134). O DIL é uma forma original que não convém tratar em termos de DD-DI.

De acordo com Authier-Revuz (2001) a trilogia DD, DI, DIL é uma evocação parcial e empobrecedora do campo da representação do discurso do outro no discurso. Parcial porque, de um lado, existem outras formas, tais como o discurso direto livre (DDL) e, de outro, as modalizações em discurso segundo. E empobrecedora porque ela não situa outras formas de representação num discurso, de um outro discurso. Em todo discurso temos a presença permanente de "outros lugares" , do "já dito" dos outros discurso condicionando todas as nossas palavras e ressoando nelas ${ }^{3}$.

No que se refere à modalização em discurso segundo, Authier- Revuz (2001) faz algumas observações. Considerem-se os enunciados seguintes ${ }^{4}$ :

(a) João fez um longo passeio. (DD)

(b) Maria disse que João fez um longo passeio. (DI)

\footnotetext{
${ }^{3}$ A autora se fundamenta em duas teorias: "o 'dialogismo' de Bakhtin, que afirma que todo discurso se faz no 'meio do já dito de outros discursos'; e o 'interdiscurso' ao qual se refere Pêcheux quando postula que todo discurso enunciado por um "eu" em um dado momento, "fala em um outro lugar, antes e independentemente'." (Authier-Revuz, 2001, p. 135)

${ }^{4}$ Os exemplos citados nesta seção são os mesmos usados por Authier-Revuz (2001).
} 
(c) João fez, segundo Maria, um longo passeio. (Modalização em discurso segundo)

Temos: (a) é uma afirmação sobre um acontecimento qualquer do mundo; (b) é uma afirmação referente a um acontecimento diferente de (a), e que é um acontecimento particular, um outro ato de enunciação; (c) é uma afirmação sobre o mesmo acontecimento de (a), modalizada por remeter a um outro discurso, caracteriza-se ela mesma como "segunda" dependente desse outro discurso. "Asserções simples, as formas do tipo segundo fulano inscrevem-se num paradigma de elementos modalizadores diversos, cuja finalidade, em seu interior, é a de modalizar pela referência a um outro discurso" (Authier-Revuz, 2001, p. 136). Na modalização destacam-se dois modos, se ela recai sobre o conteúdo da afirmação, por exemplo, João fez um longo passeio, segundo $x$ ( de acordo com $x$, é $x$ quem 0 diz); ou sobre 0 emprego de uma palavra, tida como emprestada de um exterior, por exemplo, João espaireceu longamente como diria $x$ (para falar de modo $x$, segundo as palavras de $\mathrm{x}$, como diria $\mathrm{x}$ ). Esse último caso a autora chama de modalização autonímica em discurso segundo.

Uma oposição considerada importante por Authier-Revuz é a questão do signo-padrão/signo autônimo. Observemos os enunciados seguintes:

(d) A casa de campo (Villa) está em mau estado.

(e) Villa emprega-se mais freqüentemente para as residências de férias.

O signo villa não tem o mesmo estatuto, nem o mesmo funcionamento sintático em (d) e (e). Em (d) villa é um signo padrão e ele remete, como referente, a um elemento do mundo (no caso um determinado tipo de casa). Em (e) villa é um signo autônimo e ele remete, como referente, a palavra villa. Em (d) usa-se o signo villa para nomear deterninada coisa, ao passo que em (e) menciona-se o signo "villa" - é o signo, a palavra, que é "mostrada".

A oposição padrão/autônimo ou usar/mencionar é, segundo a autora, essencial no campo do DR porque o DD e DI derivam, respectivamente, desses dois modos semióticos:

No DI, o enunciador relata um outro ato de enunciação e, usando suas próprias palavras, pelas quais ele reformula as palavras de outra mensagem: o modo semiótico de DI, é de maneira homogênea, o modo padrão. No DD, o enunciador relata um outro ato de enunciação e usando suas próprias palavras na descrição que faz da situação de enunciação e (quem fala, a quem, quando...?), ou seja, 
naquilo que chamamos sintagma introdutor, mas faz menção às palavras da mensagem que relata. O modo semiótico de DD é, assim., heterogêneo: padrão no sintagma introdutor, ele é autônimo na parte "citada", isto é, mostrada. (Authier-Revuz, 2001, p. 139)

No campo do discurso relatado a autora cita ainda ilhas textuais que estão associadas à modalização autonímica. Vejamos o exemplo:

(f) A villa de João, como ele chama seu quartinho, está em mau estado.

Temos aqui a superposição de dois enunciados:

A villa de João está em mau estado. (villa: signo-padrão)

João chama seu quartinho de villa. (villa: signo autônimo)

O enunciador fala da coisa villa, e, além disso, fala da palavra villa com a qual ele fala da coisa. Essa configuração complexa dá-se o nome de modalização autonímica. Ela pode-se realizar por comentário explícito (João espaireceu longamente, como diria $\mathrm{x}$ ) ou se realiza pelo simples sinal tipográfico (das aspas ou do itálico) ou sinal conotativo da oralidade:

(g) A "villa" de João está em mau estado.

Observemos um outro exemplo:

(h) Essas políticas de cunho "humanitário" levaram mais em conta as minas de cobalto e ferro do país que as mulheres e as crianças.

Esse caso requer um trabalho interpretativo para assinalar a configuração da modalização autonímica do campo da referência um outro discurso. Temos, nesse caso, o que foi chamado pela autora de ilha textual, que é apenas uma ocorrência de imagem particular de funcionamento do sinal de modalização autonímica: aquelas extremamente freqüentes na imprensa, em particular, na qual o DI, relatando um outro ato de enunciação num modo que é o seu, ou seja, o da reformulação, assinalada, localmente, um elemento como "não traduzido", como fragmento conservado da mensagem de origem.

\subsubsection{As formas do Discurso relatado (DR)}

Primeiramente é importante ressaltar que um DR não relata uma frase ou um enunciado e sim um ato de enunciação (Authier-Revuz, 2001). Assim, um ato de enunciação $\mathbf{E}$, definido por um par $\mathbf{L}, \mathbf{R}$, numa situação $\mathbf{S I T}$, com seu Tempo e seu Lugar e um acontecimento particular que é o ato de enunciação 
e que é objeto da mensagem $\mathbf{M}$ de $\mathbf{E}$; e sendo ele mesmo, definido por I, $\mathbf{r}$, sit...

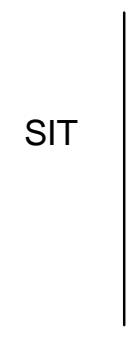

$E: L$

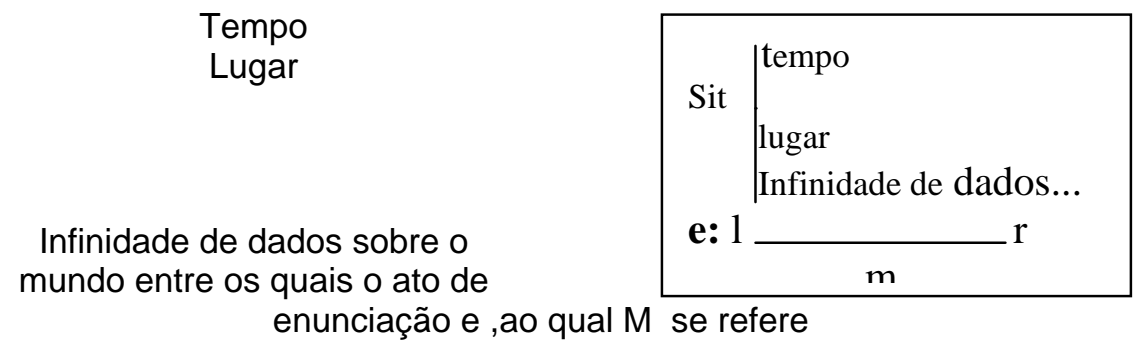

enunciação e ,ao qual M se refere

$\mathrm{R}$

M: mensagem caracterizada como constituindo um DR

Sobre essa base a autora faz dois tipos de observações: sobre a questão das fronteiras do DR e sobre a questão do sentido dos enunciados tais quais o DR a faz aparecer.

Sobre as fronteiras do DR: o discurso relatado supõe que e (o objeto de M) seja diferente de E. É o que significa relatar um outro ato de enunciação, essa diferença pode abarcar todos os parâmetros $(\mathbf{L} \neq \mathbf{I}, \mathbf{R} \neq \mathbf{r}$, Tempo $\neq$ tempo, Lugar $\neq$ lugar) ou apenas abarcar uma parte desses parâmetros. Estabelecese a fronteira (não estrita), além da qual não se estaria mais no $D R$, a necessidade: de um traço semântico de "dizer", de uma informação mínima sobre o elemento $\mathrm{m}$ de e.

Sobre a questão do sentido: Não se deve confundir o sentido de um enunciado, isto é, de um acontecimento de fala único na situação particular de enunciação, com o significado de uma frase, descritível de modo diferenciável no interior o sistema da língua.

O que caracteriza todo DR (DD ou DI) é que a situação de enunciação e na qual e através da qual a mensagem $m$ de e ganha sentido não é um dado de fato, como em um ato de fala ordinário, mas está presente apenas pela descrição que $L$ faz dela em $M$.

Disso a Authier-Revuz (2001, p. 149) conclui o seguinte:

I) Que nenhum DR, por mais longa e minuciosa que seja a descrição da situação de enunciação dada por $\mathbf{L}$ no sintagma introdutor, pode ser considerada como restituição "completa", fiel de outro ato de enunciação que ele tenha como objeto 
II) Que um DD escrupulosamente textual não pode, por isso, ser considerado como fiel ou objetivo. Citar $\mathrm{m}$ exatamente não impede que e seja reconstruído, descrito por $\mathbf{L}$.

III) Disso decorre a importância, nos DR, dos sintagmas introdutores, nas quais estão em jogo a variedade lexical dos verbos dicendi, a das "descrições definidas" pelas quais um indivíduo (I, r) pode ser nomeado.

\subsubsection{Discurso direto (DD) x Discurso indireto ( DI)}

Como já foi dito o DI não é obtido por uma transformação de subordinação a partir do DD, para Authier-Revuz (2001) os DD são dois modos radicalmente distintos de representação de um outro ato de enunciação. O DD corresponde a uma operação de citação da mensagem do ato relatado, o outro, o DI corresponde a uma operação de reformulação, isto é de produção de um enunciado como tendo o mesmo sentido que a $\mathrm{m}$ do ato relatado. Disso decorre uma oposição entre o $D D$, que apresenta uma estrutura heterogênea, e - DI, que apresenta estrutura homogênea, da sintaxe normal da língua. A dualidade (heterogeneidade) do DD, em face da unidade (homogeneidade) do DI, pode ser observada nos seguintes planos:

Estatuto semiótico: o caráter heterogêneo do DD, com seu sintagma introdutor e sua parte citada; o caráter homogêneo do DI no qual $\mathbf{L}$ reformula globalmente $\mathrm{m}$ em suas palavras.

Estrutura sintática: duas construções para DD (introdução e parte citada); uma única construção em DI, correspondendo a uma frase normal da língua, é o sentido e não uma forma sintática particular, que faz com que reconheçamos um DI.

Modalidade de enunciação: um enunciado, normalmente, tem apenas uma modalidade de enunciação entre as possibilidades afirmativa, interrogativa e imperativa. O DD, contrariamente, apresenta uma intercalação de modalização de enunciação de uma frase (a de $\mathbf{m}$ ) em outra (a de $\mathbf{M}$ ). Assim todas as combinações dessas modalidades são possíveis:
(i) A João disse
a Sofia virá.
B João disse
b Será que Sofia virá?
C João, diga
c Sofia, venha! 
O DI, ao contrário, apresenta apenas uma modalidade de enunciação: a de M, escolhida por L:

João disse que...

Será que João disse que...?

João, diga que...!

Quadro de indicações dêiticas: No que tange o funcionamento dos elementos dêiticos, o DD ainda apresenta uma estrutura heterogênea , já que, todos os elementos do sintagma introdutor são interpretados em função da situação de $\mathbf{E}$, e na parte citada, os elementos dêiticos esperam ser interpretados em função da situação e, relatada. Desse modo, o DD constitui o único caso na língua em que vários eu, você, aqui/agora pode ter em uma única frase valores diferentes:

(j) Ele me disse: "eu venho te ver amanhã."

$$
\begin{aligned}
& \text { ele } \Leftrightarrow \text { eu } \\
& \text { me } \Leftrightarrow \text { te ver }
\end{aligned}
$$

Ao contrário, o DI, possui apenas um quadro de indicações para os dêiticos, o da situação efetiva de enunciação $E$.

(k) Ele me disse que ele viria me ver no dia seguinte.

$$
\text { ele } \Leftrightarrow \text { ele }
$$$$
\mathrm{me} \Leftrightarrow \mathrm{me}
$$

Designação por descrições definidas: em DD as designações são escolhidas por $\mathbf{L}$ como adequadas à SIT e à $\mathbf{R}$, nos sintagmas introdutores, e são, na parte mencionada, as escolhidas por I como adequadas à sit e à $\mathbf{r}$. Em DI, as designações são homogeneamente feitas em função de E.

Elementos expressivos, exclamativos: Em DD justapõe-se, numa cadeia heterogênea, elementos ligados a subjetividade de $\mathbf{L}$ no sintagma introdutor, e de I na m mencionada. Em DI, todo elemento desse tipo será, necessariamente, interpretado como emanado de $\mathbf{L}$.

(I) "Ele, infelizmente, disse: "eu virei, meu coronel!" infelizmente tomado por $\mathbf{L}$ como sendo de sua responsabilidade. responsabilidade de $\mathrm{I}$. meu coronel mencionado por $\mathbf{L}$ como estando sobre a (m) "Ele, infelizmente, disse que viria, meu coronel." 
infelizmente e meu coronel tomados por $\mathbf{L}$ como sendo de sua responsabilidade.

Alguns casos particulares: Existem casos em DD que as palavras que $\mathbf{L}$ " mostra" são interpretadas como palavras escolhidas por $\mathbf{L}$ como sendo as que resumem perfeitamente, dizendo a verdade, o conteúdo da mensagem de $\mathbf{m}$. Essa operação de reformulação pode ser explicitada ou deixada para interpretação.

(n) Como Debray-Ritzen que diz (eu parafraseio): "Para o rapaz que tem 80 desestruturar os colégios"

(de Q.I.) não vale a pena estudar, ele vai

(o) O que as tragédias de Racine nos diz é: "O homem está condenado a infelicidade."

No DI, há uma forma que Authier-Revuz (2001) Chama de quase textual: ele diz que ".........", muito usada na imprensa:

(p) O ministro declarou que "para sua grande satisfação, ele estava em condições de afirmar que sua política de emprego iria, dentro em breve, ser coroada de sucesso".

Esse exemplo pode ser analisado como um DI quase textual que corresponde a uma m de e. "Não se deve analisar DI quase textual como um DI "seguido de DD", a parte entre aspas não é DD., o funcionamento do dêiticos o exclui dessa possibilidade, semioticamente, é uma "ilha textual" estendida até a mensagem inteira que nos interessa". (Authier-Revuz, 2001, p. 158).

Vimos, então, que DI não é, pois, um DD “subordinado", mas que supõe primeiro, decodificar, ou seja, interpretar um enunciado $\mathbf{m}$, tendo em vista sua situação de enunciação e, segundo, re-codificar, ou seja, produzir um novo enunciado $\mathbf{M}$ que, levando em consideração a situação $\mathbf{E}$, será considerado por $\mathbf{L}$, como equivalente ao sentido que foi interpretado.

\subsubsection{Discurso direto livre (DDL) e Discurso indireto livre (DIL)}

DDL e DIL são formas não marcadas, puramente interpretativas de representação de um ato de enunciação. Não existe, efetivamente, frases que, fora do contexto, possa ser caracterizada como sendo DDL ou DIL. Vejamos os exemplos:

(q) Eu vi Maria há pouco. Estou farto vou, pedir demissão! DDL

(r) Eu vi Maria há pouco. Ela está farta, vai pedir demissão! DIL 
No DDL todos os dêiticos de pessoa, tempo e lugar são, como no DD, os de e. O que significa que se pode considerar o DDL um DD sem introdutor e sem marca tipográfica. No DIL, segundo Authier-Revuz (2001, p. 160), a situação é mais complexa, "os dêiticos de pessoa são obrigatoriamente os de $\mathbf{E}$, o que significa que eles são, como em DI, reformulados em função de $\mathbf{L}$ e $\mathbf{R}$. Mas não acontece sempre com os dêiticos de tempo, os verbais ou adverbiais." Assim, mesmo no plano dos elementos dêiticos, o DIL não pode ser considerado como um "DI sem elemento introdutor", pois ele mistura elementos de $\mathbf{L}$ e I.

\subsection{A problemática do gênero do discurso}

A noção tradicional de gênero foi inicialmente elaborada nos âmbitos da poética, de uma reflexão sobre a literatura, e da retórica, esta última propôs a célebre tripartição entre gênero judiciário, deliberativo e epidítico. Atualmente há uma ampliação da noção de gênero ao conjunto das atividades verbais. Questões relativas aos gêneros do discurso estão, cada vez mais, marcando presença nos trabalhos ligados às teorias da enunciação, à análise do discurso, à lingüística textual etc.

De acordo com Maingueneau (2004b), no âmbito da AD, o estudo de questões relativas ao gênero do discurso auxilia na determinação do funcionamento discursivo do objeto analisado. A noção de gênero representa um papel central em uma análise do discurso que não vise considerar o lugar independente da língua que the autoriza (redução sociológica) nem a língua independente dos lugares dos quais ela faz parte (redução lingüística).

São muitas as tipologias textuais que circulam hoje. Brandão (2000) aponta alguns tipos de classificações:

As tipologias funcionais: Jakobson (1963) propõe uma formulação geral do gênero em termos de funções (referencial, emotiva, conativa, fática, metalingüística, poética) que envolvem todo ato de comunicação verbal.

As tipologias enunciativas: estão fundadas nas diferentes formas da presença das marcas da enunciação no discurso. Essas marcas remetem aos componentes da cena enunciativa: interlocutores, lugar, tempo.

As tipologias textuais: Adam (1987) vai se dedicar a desenvolver uma hipótese sobre as unidades mínimas de composição textual, procurando deslocar a análise de Bakhtin do campo sociolingüístico dos gêneros do 
discurso ao mais estritamente lingüístico da textualidade. Isto é, refletir sobre certas categorias que estão na base de toda composição textual, tendo em vista uma teoria de tipologia baseada na estrutura seqüencial prototípica dos textos. Propõe cinco tipos de estruturas seqüenciais de base: narração, descrição, argumentação, explicação e diálogo.

A tipologia sócio-interacionista: Para Bakhtin (1992), os discursos são produzidos de acordo com os diferentes campos de atividade humana, cada um desses campos exige uma forma específica de uso da linguagem, um gênero diferente de discurso, os gêneros do discurso são diferentes formas de uso da linguagem que varia de acordo com os diversos campos de atividade do homem.

Rastier (2001, p. 251) distingue três concepções de gênero: a classe, o tipo e a linhagem ${ }^{5}$ :

\begin{abstract}
A concepção classificatória deve confrontar todos os problemas ordinários de taxionomia, cujo menor, não é a variabilidade de critérios. Certamente, tentou-se reformar essa concepção utilizando a noção de parentesco, correndo o risco de multiplicar e enfraquecer sem saber um meio de os hierarquizar. A concepção tipológica deve caracterizar as relações entre tipo e ocorrências. Essas duas primeiras concepções de gênero, a classe e o tipo revelam a problemática lógico-gramatical. A terceira concepção, considera o texto como uma geração dentro de uma linhagem de reescrituras, os gêneros seriam de linhagens genéticas específicas.
\end{abstract}

O autor faz uma distinção entre tipo de texto e gênero de discurso, os tipos de textos são em geral classes que levam em conta apenas um critério, o analista, dependendo de sua necessidade, se baseia em uma categoria: romance escrito em primeira ou terceira pessoa, texto longo ou curto, antes ou depois de 1945, etc. Os gêneros são, para Rastier (2001, p. 253), definidos por um conjunto de critérios "a coesão do conjunto de critério, tanto do plano do significante quanto do significado, estrutura a textualidade"

Desse modo, tanto Adam quanto Benveniste se inscrevem na concepção de tipo, enquanto Bakhtin e Maingueneau se inscrevem na problemática das reescrituras das linhagens, tal como descritas por Rastier.

A diversidade de pontos de vista mostra a complexidade da questão do gênero, não há, nas tipologias enunciativas, a inscrição social dos enunciados. Já nas tipologias comunicacionais ou situacionais não levam em consideração

\footnotetext{
${ }^{5}$ La classe, le type et la lignée.
} 
os funcionamentos lingüísticos dos textos. Segundo Maingueneau (2004a) o que interessa para a $A D$, e portanto para esse trabalho, seria 0 desenvolvimento de uma tipologia discursiva que não separasse, de um lado, as caracterizações ligadas às funções, e de outro, as caracterizações lingüístico-enunciativas.

\subsubsection{Maingueneau e os gêneros de discurso}

Maingueneau $(1997,2001,2004 a, 2004 b)$ vai dando à problemática do gênero um redimensionamento, trazendo- a para o cerne das questões da AD. $A$ noção de gênero do discurso permite à $A D$ um contato com a Pragmática. É através desta que Maingueneau $(1997,2001)$ desenvolve o conceito.

Ao se desenvolver em torno de uma reflexão sobre a interação enunciativa e sobre a pertinência contextual dos enunciados, as correntes pragmáticas tornaram a reflexão sobre os gêneros um eixo principal de qualquer abordagem dos enunciados. (Maingueneau, 2001, p. 65)

Traçando um paralelo entre ato de fala e gênero do discurso, o autor mostra que um gênero implica condições de ordem comunicacional e estatuária.

O gênero de discurso aparece dessa maneira como uma atividade social de um tipo particular que se exerce em circunstâncias adaptadas, com protagonistas qualificados e de maneira apropriada. (Maingueneau, 2001, p. 66)

Esse contato com a Pragmática reaparece na obra Análise de textos de comunicação (2004a, p. 69 e 70), na qual o autor, para caracterizar o gênero, recorre a três metáforas: o contrato, o papel e o jogo.

\footnotetext{
Dizer que o gênero de discurso é um contrato significa afirmar que ele é fundamentalmente cooperativo e regido por normas. Todo gênero do discurso exige daqueles que dele participam a aceitação de um certo número de regras mutuamente conhecidas e as sanções previstas para quem as transgredir .

Falar de papel é insistir no fato de que cada gênero de discurso implica os parceiros sob a ótica de uma condição determinada e não de todas as suas condições possíveis.

E como um jogo um gênero implica um certo número de regras preestabelecidas mutuamente conhecidas e cuja transgressão põe um participante "fora do jogo".
}

Os gêneros do discurso não podem ser considerados como formas que estão à disposição do locutor, a fim de que este molde seu enunciado nessas formas. Trata-se de uma atividade social, que, por isso mesmo, é submetida a 
um conjunto de condições de êxito. Essas condições envolvem elementos de ordem diversa: uma finalidade reconhecida; um estatuto de parceiros legítimos; o lugar e o momento legítimos; um suporte material; uma organização textual. Maingueneau demonstra que, ao abordar questões relativas à generacidade, é preciso estabelecer uma articulação do social com o lingüístico, pois ao estudarmos gêneros do discurso mobilizamos tipologias: enunciativa, funcional e situacional.

O autor faz ainda uma distinção entre gêneros e tipos de discurso, "os gêneros de discurso pertencem a diversos tipos de discurso associados a vastos setores de atividade social. Assim, "talk show" constitui um gênero de discurso no interior do tipo de discurso "televisivo" que, por sua vez, faz parte de um conjunto mais vasto, o tipo de discurso "midiático" (Maingueneau, 2004a, p.62). A sociedade, é dividida em diferentes setores ou campos ${ }^{6}$ : lazer, saúde, ensino, produção de mercadoria etc, que correspondem a grandes tipos de discurso. A reportagem constitui um gênero no interior do tipo de discurso midiático, o gênero sermão insere-se no tipo de discurso religioso, etc. Desse modo, o tipo de discurso regula os gêneros de discurso inseridos em seu interior.

Maingueneau (2004b) distingue dois regimes de generalidade: os gêneros conversacionais e os gêneros instituídos, esses dois regimes obedecem a lógicas bastante distintas:

Os gêneros conversacionais: Sua composição e sua temática são muito instáveis, sua configuração muda sem cessar. As interações conversacionais são dificilmente divisíveis em gêneros bem distintos, uma vez que há uma constante estratégia de ajustamento entre os locutores.

Os gêneros instituídos: Maingueneau (2004b) distingue quatro modos de generalidade instituída, de acordo com a relação que se estabelece entre aquilo que o autor chama de "cena genérica" e "cenografia". Na cena da

\footnotetext{
${ }^{6}$ Essa noção de campo foi tomada de Bourdieu (2004), segundo o autor "para compreender uma produção cultural (literatura, ciência etc) não basta referir-se ao conteúdo textual dessa produção, tampouco referir-se ao contexto social contentando-se em estabelecer uma relação direta entre o texto e o contexto(...), entre esses dois pólos, muito distanciados, (...) existe um universo intermediário que chamo campo literário, artístico, jurídico ou científico, isto é, o universo no qual estão inseridos os agentes e as instituições que produzem, reproduzem ou difundem a arte, a literatura ou a ciência. Esse universo é um mundo social como os outros, mas que obedece a leis sociais mais ou menos específicas." ( Bourdieu, 2004, p. 20)
} 
enunciação, Maingueneau distingue três cenas que se complementam: a cena englobante, a cena genérica e a cenografia.

A cena englobante é aquela que corresponde ao tipo de discurso: político, religioso, etc. No entanto, dizer que a cena enunciativa de um enunciado político é a cena englobante política não é suficiente para especificar a atividade verbal, tomamos contato não com o político diretamente e sim com um gênero de discurso particular. $O$ discurso político pode tratar-se de um discurso de um chefe de Estado, de um jornal militante, etc. Aqui podese falar em cena genérica. Essas duas cenas, a englobante e a genérica definem aquilo que Maingueneau (2004b) chama de quadro cênico do texto. $\mathrm{Na}$ verdade, não é diretamente com o quadro cênico que os locutores são confrontados, mas sim com uma cenografia. A cenografia não é simplesmente um quadro, como se o discurso surgisse no interior de um espaço já construído e independente. A enunciação se desenvolve colocando em evidência seu próprio dispositivo de fala, o discurso pretende convencer instituindo a cena da enunciação que o legitima.

Vejamos os quatro modos de generalidade propostos por Maingueneau:

Gêneros instituídos de modo (1): São gêneros instituídos que não são, ou são pouco, sujeitos à variação, por exemplo, lista telefônica, bula de remédio, etc. Eles são caracterizados por possuírem esquemas composicionais preestabelecidos e bastante rígidos.

Gêneros instituídos de modo (2): São gêneros nos quais os locutores produzem textos individuais, mas submetidos a alguns parâmetros de ato comunicacional: jornal televisivo, notícia, guia de viagens. Eles possuem em geral, uma cenografia preferencial, mas toleram cenografias mais originais.

Gêneros instituídos de modo (3): Nesses gêneros (publicitário, musicais) não existe uma cenografia preferencial, saber que tal texto é um anúncio publicitário não permite prever através de qual cenografia ele vai ser enunciado.

Gêneros instituídos de modo (4): Esses são gêneros propriamente autorais. Eles não se contentam em seguir um modelo preestabelecido, eles procuram captar seu público instaurando uma cena de enunciação original.

Assim como propõe Maingueneau, levaremos em conta critérios lingüísticos, funcionais e situacionais na determinação dos gêneros de 
discurso, visto que o discurso de divulgação científica é indissociável de certos funcionamentos lingüísticos, mas corresponde também a uma função social e a certo lugar de produção e circulação.

A primeira questão abordada refere-se à $A D$ e as suas transformações ao longo do tempo. A opção por colocar a AD em perspectiva histórica deu-se pelo fato de considerarmos que todo trabalho científico tem sua sustentação teórica em algum lugar e que esse lugar necessita ser primeiro retomado e depois redirecionado. Em seguida, tratamos de dois conceitos de extrema relevância para o trabalho, visto que são categorias de análise do corpus: o DR e o gênero de discurso.

No que diz respeito ao DR, o nosso corpus é composto por textos de DC publicados em revistas especializadas, ou seja, está diretamente relacionado com a mídia impressa e com o jornalismo científico. Desse modo, a exposição do funcionamento do discurso relatado nos textos mostrou-se importante, uma vez que o campo jornalístico faz grande uso do DR (principalmente do discurso direto) na construção dos efeitos de verdade e credibilidade das informações publicadas.

Sendo a DC uma prática discursiva que circula em uma grande variedade de gêneros (temos a DC em artigos, reportagens, perguntas/respostas, obras literárias, panfletos, etc), o estudo do gênero também mostrou-se relevante, uma vez que os textos analisados pertencem a gêneros diferentes. Em cada gênero que assume a $D C$ se estrutura de modo específico, sofrendo certas coerções, incluindo aí a presença maior ou menor de DR. 


\section{Cap. II \\ CIÊNCIA E DIVULGAÇÃO CIENTÍFICA}

Nas últimas décadas, a ciência e a tecnologia passaram a ocupar espaço cada vez maior na imprensa voltada para o homem comum. Temas como manipulação genética, saúde pública, biotecnologia, impacto de novas técnicas médicas etc., têm cobertura regular da mídia. Os saberes que, tradicionalmente, circulavam apenas nas comunidades científicas direcionados a um público composto por cientistas passam a circular em meio a um público leigo em matéria de ciência.

Neste capítulo, iniciamos apresentando algumas reflexões feitas por Bourdieu $(1983,2004)$ acerca do campo científico, já que não nos parece possível abordar a divulgação científica sem antes tratar da ciência ou do discurso científico, mesmo que em termos bastante genéricos. Em um segundo momento, entraremos no cerne da produção e funcionamento do discurso de divulgação científica e de como ele é entendido por Bueno (1985), AuthierRevuz (2001) e Zamboni (2001). Por fim, faremos um traçado histórico das principais publicações de divulgação científica no Brasil, uma vez que nosso corpus de análise é constituído por textos publicados em revistas de DC. Nesse sentido, parece-nos conveniente fazer, sem pretensão à exaustividade, um breve histórico desse tipo de publicação no Brasil.

\subsection{Uma reflexão sobre o campo científico}

Contrariando uma tradição que via a ciência como auto-suficiente, gerando-se a si própria, fora de qualquer intervenção do mundo social, Bourdieu elabora a noção de campo científico. Segundo o autor:

\footnotetext{
...para compreender uma produção cultural (literatura, ciência etc.) não basta referir-se ao conteúdo textual dessa produção, tampouco referir-se ao contexto social contentando-se em estabelecer uma relação direta entre o texto e o contexto(...) entre esses dois pólos (...) existe um universo intermediário que chamo campo literário, artístico, político ou científico. (Bourdieu, 2004 p. 20)

O campo seria, então, o universo (relativamente autônomo e com leis
} próprias) no qual estão inseridos os agentes e as instituições que produzem ou difundem a arte, a literatura e a ciência. 
No que diz respeito ao campo científico, surge a problemática acerca do grau de autonomia que ele usufrui. Bourdieu aborda a importância de escapar, de um lado, da "ciência pura", livre de qualquer necessidade social, e de outro, da "ciência escrava", sujeita a todas as demandas político-econômicas. O campo científico, segundo Bourdieu, é um mundo social, e sendo assim, faz imposições e solicitações que são relativamente independentes das pressões do mundo social externo que 0 envolve. As pressões externas são mediatizadas pela lógica do campo, que possui capacidade de refratar, isto é, retraduzir sobre uma forma específica as pressões ou demandas externas; "o grau de autonomia de campo tem por indicador principal seu poder de refração, de retradução." (Bourdieu, 2004 p. 22).

Um outro ponto abordado pelo autor são as relações de poder que se estabelecem no interior do campo. A estrutura de um campo em determinado momento é a estrutura da distribuição do capital científico ${ }^{7}$ entre os diferentes agentes engajados nesse campo. Esse capital

Repousa, por sua vez, sobre o reconhecimento de uma competência que, para além dos efeitos que ela produz e em parte mediante esses efeitos, proporciona autoridade e contribui para definir não somente as regras do jogo, mas também suas regularidades, as leis segundo as quais vão se distribuir os lucros nesse jogo, as leis que fazem que seja ou não importante escrever sobre tal tema, que é brilhante ou ultrapassado, e o que é mais compensador publicar no American Journal de tal e tal do que na Revue Française disso e daquilo. (Bourdieu, 2004 p. 27).

No entanto, o que faz a especificidade do campo científico seria "aquilo sobre o que os concorrentes estão de acordo acerca dos princípios de verificação da conformidade ao "real", acerca dos métodos comuns de validação de teses e de hipóteses.". Nesse sentido, as publicações e as reuniões constituem lugares privilegiados (no interior do campo) para anunciar resultados, receber contribuições, ouvir críticas submeter a julgamento, etc, visto que, a circulação de novos saberes é importante para dar continuidade ao processo evolutivo do conhecimento.

\footnotetext{
${ }^{7}$ De acordo com Bourdieu (2004), o capital científico é uma espécie de capital simbólico que consiste no reconhecimento (ou no crédito) atribuído pelo conjunto de pares-concorrentes no interior do campo científico. Existem duas formas de poder que correspondem a duas espécies de capital científico. De um lado, o poder institucionalizado, que está ligado à ocupação de posições importantes nas instituições científicas, direção de laboratórios ou departamentos, pertencimento a comissões, etc. De outro, um poder específico, "prestígio" pessoal que é mais ou menos independente do precedente.
} 
O discurso científico, produzido por uma comunidade investida de competência científica ${ }^{8}$, é direcionado a essa mesma comunidade de tal modo a fazer coincidir o público de seus produtores com o público de seus consumidores: escreve-se apenas para seus pares. Destinado a um público específico, o discurso científico tem sua circulação restrita ao campo científico.

Depois de traçadas as concepções sobre campo e discurso científico, cabe-nos refletir sobre a divulgação científica. Em seu livro "Usos sociais da ciência", Bourdieu aborda, mesmo que superficialmente, a questão da divulgação científica. Segundo o autor, os cientistas deveriam "se não trabalhar, eles próprios, pela divulgação, dos resultados do seu trabalho, pelo menos trabalhar para controlar tanto quanto possível esse processo de divulgação", ou seja, "levar ao conhecimento de um público tão amplo quanto possível um certo número de resultados da pesquisa" (Bourdieu, 2004 p. 79). No que se refere à divulgação científica na mídia, em particular na televisão, Bourdieu, diz que o problema está nos falsos problemas ou problemas mal colocados pela mídia. Quando se é entrevistado, segundo o autor, o cientista é levado a discutir sobre assuntos de interesse jornalístico e não científico.

\subsection{As práticas de divulgação científica}

A divulgação científica é entendida, de modo geral, como uma atividade de difusão de conhecimento científico, dirigida para fora do seu contexto originário - de comunidade científica de limites restritos - mobilizando diferentes recursos, técnicas e processos para a veiculação das informações científicas e tecnológicas ao público em geral.

Além de ser uma atividade de difusão do conhecimento, a divulgação científica também pode ser vista como partilha social do saber. Na mídia impressa, a atividade de divulgar conhecimentos novos sustenta-se na função de partilha do saber, necessária diante da velocidade com que se acumulam novos saberes, se conquistam novas técnicas, se garantem novos procedimentos.

\footnotetext{
${ }^{8}$ A competência científica refere-se à "capacidade de falar e agir legitimamente (isto é, de maneira autorizada e com autoridade), que é socialmente outorgada a um agente determinado" (Bourdieu, 1983 p. 122-123).
} 
Em um artigo intitulado "jornalismo e divulgação científica", Silva (2002) descreve o papel da mídia na transmissão de conhecimento científico. Segundo ela, " caberia então à Mídia a tarefa de uma democratização dos bens e benefícios sociais" (2002, p.132). Zamboni assume a mesma posição, "a tarefa maior de exercer a partilha social do saber, levando ao homem comum o conhecimento do qual ele foi historicamente apartado e do qual foi-se mantendo cada vez mais distanciado, à medida que as ciências se desenvolviam e mais se especializavam" (Zamboni, 2001, p.49).

No entanto, o saber para mídia, aqui estamos nos referindo a mídia impressa, é diferente do saber da ciência. O saber do jornalismo é um saber para dizer, para "informar ao público". Segundo Silva, "ele parte de uma suposição, primeiro, de que o leitor quer saber e, depois, do que ele quer saber. A imprensa toma então a sua fala como um dever que irá suprir o direito e/ou a necessidade do público de se informar." (2002 p.133). Já a ciência tem em princípio o compromisso com o próprio saber e com o fazer tecnológico. As práticas discursivas da ciência adquirem significado graças a um diálogo contemporâneo (diferentes posições disciplinares e teóricas) e a um processo histórico (pelos antecedentes da pesquisa). Na prática jornalística, como observa a autora, existe um "aplainamento" sobre o fato científico, no que diz respeito a essa historicidade. Sobre esse fato, Moirand (2000) escreve:

\begin{abstract}
As descobertas médicas não são realmente explicadas, antes se explicam suas conseqüências positivas sobre a saúde (preservação do corpo); aos especialistas de catástrofes, a mídia demanda não tanto explicar o fenômeno, mas sua opinião sobre a previsão ou conselhos sobre a construção de prédios (preservação dos bens); não são os mecanismos internos das novas tecnologias que são expostos, mas a imagem da modernidade que confere sua utilização (2000 p. 21).
\end{abstract}

Assim, o que há na mídia é o alheamento ao fazer científico. Ela apresenta resultados como produtos acabados, sem expor os processos que levaram a eles.

\title{
2.2.1 Divulgação científica $x$ disseminação científica $x$ jornalismo científico
}

Antes de expormos o que entendemos por divulgação científica, apresentaremos alguns estudos feitos nesta área, tomando como ponto de partida o quadro conceitual de Bueno (1985). Em sua tese de doutorado, o 
jornalista situa a difusão científica como um gênero que se desdobra nas espécies: divulgação científica, disseminação científica e jornalismo científico.

A difusão é concebida de maneira bem ampla, como todo e qualquer processo ou recurso utilizado para a veiculação de informações científicas e tecnológicas (1985) e engloba: a difusão para especialistas e a difusão para o grande público em geral. A primeira Bueno chama de disseminação científica, a segunda de divulgação científica.

A disseminação científica comporta dois níveis: o primeiro, a disseminação intrapares, segundo Bueno, é dirigida a um público especializado com conteúdo específico e código fechado, estando ela representada nas revistas especializadas ou nas reuniões científicas, isto é, trata-se do discurso científico propriamente dito; o segundo seria a disseminação extrapares que podem ser consumidas por especialistas de áreas diferentes, ou seja, um historiador ou um lingüista podem se interessar por temas relacionados a genética como, por exemplo, a clonagem humana.

\subsubsection{O funcionamento textual-discursivo da DC}

$\mathrm{Na}$ caracterização da divulgação científica dirigida a leigos, existe uma grande preocupação no que diz respeito à linguagem no processo de

\footnotetext{
Comunicar ao público, em linguagem acessível, os fatos e princípios da ciência, dentro de uma filosofia que permita aproveitar o fato jornalisticamente relevante como motivação para explicar os princípios científicos, os métodos de ação dos cientistas e a evolução das idéias científicas (Reis, 1964, p. 353).
}

Tornar a linguagem da ciência mais acessível parece ter sido um dos primeiros objetivos da popularização da ciência, sob o argumento de ser a ciência difícil de compreender, necessitando, pois, de tradução em palavras simples para ser entendida pelos que não são cientistas (Goldsmith, 1975).

Do ponto de vista textual-discursivo, deve-se ressaltar a contribuição de duas lingüistas aos estudos das práticas de divulgação científica. Uma delas é a francesa Jaqueline Authier-Revuz e a outra é Lílian Zamboni, que faz, em seu trabalho, algumas ressalvas sobre a posição de Authier-Revuz.

\subsubsection{Authier-Revuz e a DC}

A autora afirma que nos textos de DC existe uma dupla estrutura enunciativa, que se evidencia pelo uso do discurso relatado. A reformulação 
através discurso relatado mostra não só os interlocutores e o quadro de enunciação do discurso científico (doravante D1), como também os interlocutores e o quadro de enunciação de divulgação científica (doravante D2). Segundo a autora, D1 é objeto explícito de D2, já que em D2 há menção de D1 "de modo geral, os parâmetros do ato de enunciação de D1 - pessoa, datas, lugares, modalidades e circunstâncias - estão presentes de maneira insistente no fio dos textos." (2001 p.111).

Assim, para Authier-Revuz, a DC apresenta-se como prática de reformulação de um discurso-fonte (D1) em um discurso segundo (D2), em função de um receptor diferente daquele a quem se endereça o discurso científico (discurso-fonte). A autora analisa textos franceses relativos à divulgação dirigida ao grande público, o resultado da análise leva-a a caracterizar o discurso produto da vulgarização científica como resultante de um trabalho de reformulação explícita, que "longe de esconder a maquinaria, ele a mostra sistematicamente" (2001, p. 109), em contraponto à operação de tradução propriamente dita, que "esconde" o trabalho de reformulação.

A esse respeito, Orlandi (2001) nos diz que não se transportam sentidos de um discurso para outro, "não se trata de tradução pois não são duas línguas diferentes, são dois discursos na mesma língua. E o que ele produz em uma ordem de discurso deve por sua vez inscrever-se em uma outra, mantendo efeito de cientificidade" (pg. 24). Segundo a autora, o divulgador não "traduz" o discurso científico para o jornalístico, mas trabalha no entremeio desses dois discursos na mesma língua.

No nível do fio discursivo, a DC apresenta, para Authier-Revuz, a forma dos dois discursos (D1 e D2). As formas de D1 a autora chama de científica (C) e as formas de D2 ela denomina cotidiana (Q). Ora essas formas estão justapostas colocadas em equivalência metalingüística, ora uma se sobrepõe à outra ocorrendo um distanciamento metalingüístico. Esse distanciamento é marcado pelo uso de recursos como itálico e aspas, segundo Authier-Revuz, "as palavras entre aspas são marcadas como pertencentes a um discurso outro" (2001 p. 118). Nos textos analisados pela autora, ora são as palavras científicas que estão entre aspas ora são as palavras do cotidiano que estão aspeadas, ou seja, mostrando que pertencem a um outro discurso. Para a autora, esse dialogismo é marcante nos textos de DC "o divulgador, com as 
palavras dos dois, fala para - no lugar do um, científico, e fala para - na intenção do outro, público; é, pois, um discurso marcado pela marcado por essa dupla determinação." (2001 p. 122).

Concluindo sua análise, Authier-Revuz propõe que o texto de DC provoca um efeito sobre o leitor, o de ser apenas aproximativo, uma imagem degradada do texto científico, dito absoluto, homogêneo e monológico.

\subsubsection{Zamboni e a DC}

Para Zamboni (2001), o que há na DC é um intenso processo de formulação de um novo discurso e não de reformulação, como defende AuthierRevuz (2001). Para comprovar sua tese, a autora faz uma série de ressalvas ao trabalho de Authier no que se refere ao quadro de enunciação e ao fio do discurso.

Zamboni diz que em seu trabalho Authier-Revuz coloca o discurso relatado como caracterizador do discurso de DC, sobre esse ponto Zamboni afirma que o discurso relatado está presente em um grande número de texto, seja ele de DC ou não. Segundo ela, o discurso relatado não pode ser considerado um traço caracterizador da DC "Se o discurso do "outro", o cientista, aí se faz presente, deve-se mais ao fato de ser o DC uma modalidade entre os demais discursos de transmissão, e menos um traço de caracterização intrínseca e privilegiada." (2001 p. 56). Além disso, o discurso relatado também estaria presente no discurso científico.

Um outro ponto abordado por Zamboni é que as citações em discurso direto que aparecem nos texto de DC já são falas vulgarizadas do discurso científico, ou seja, já não seria um discurso primeiro, o científico. Desse modo, "a entrevista e os depoimentos tomados dos próprios cientistas pelo divulgador já vêm configurados como discurso de DC." (2001 p. 56).

Aqui, mais uma vez, Zamboni ressalta que não é exclusivo da DC científica ter duas formas discursivas, nem é sua exclusividade também "o modo como esses dois discursos se relacionam na materialidade da língua, ou seja, um modo heterogêneo, que passa de um discurso a outro em operações que se mostram, que exibem o processo de seu próprio fazer (...)” (2001 p. 67). Segundo a autora, esse processo ocorre em qualquer discurso de especialidade ao ser transformado em discurso de transmissão de informação. 
Sobre as análises feitas por Zamboni vale fazermos uma observação, Authier-Revuz afirma que a DC funciona dentro de um quadro global de discurso relatado e não que a DC contém muito discurso relatado como interpreta Zamboni, nesse ponto a análise da autora parece inapropriada.

A segunda observação feita por Zamboni, no que diz respeito ao fio do discurso, é de que Authier-Revuz, tomando a DC como tradução, privilegia a enunciação do "outro" no discurso do "eu". Olhando a DC com um referencial teórico que busca apreender o trabalho do "eu", Zamboni interpreta as marcas do trabalho de "tradução" de D1 para D2 como realizações efetivas do sujeito.

Nesse ponto é importante fazermos algumas observações, AuthierRevuz não afirma que a DC é uma tradução como diz Zamboni. O que AuthierRevuz diz é que a DC inscreve-se em um conjunto no qual estão incluídos a tradução, o resumo, e a resenha. A autora afirma que no D2 produto-detradução o trabalho de reformulação se mantém implícito. Ao contrário o D2 produto-de-DC dá-se explicitamente como um trabalho de reformulação de D1(discurso fonte).

Zamboni analisa o trabalho do sujeito na DC tomando como referencial teórico o trabalho de Possenti (1995). Para Possenti, o reconhecimento da presença do outro não elimina o trabalho do sujeito falante do discurso, o autor critica a idéia de sujeito totalmente assujeitado, para ele, admitir o sujeito na língua não é atribuir a esse sujeito a total intencionalidade, a unicidade etc. e negar o inconsciente, o histórico, o social. Zamboni, apoiada nas idéias de Possenti (1995) afirma que o sujeito opera um trabalho não apenas com a língua mas sobre a língua.

Para a autora, o discurso de DC "usando o discurso científico como uma fonte válida e legitima, constrói um discurso que não parece querer esconder o trabalho do "eu" atrás da cortina de objetividade, mas que até o mostra em vias de se produzir" (2001 p. 28). Desse modo, além de uma heterogeneidade mostrada, há nos textos de DC uma subjetividade mostrada.

Ao considerar a divulgação científica como um trabalho de formulação discursiva e não apenas de reformulação, Zamboni defende, a tese de que a DC é um gênero particular do discurso, visto que, ela está sujeita a condições de produção bastante diversas daquelas que cercam o discurso científico. 
Apoiada nos trabalhos do círculo de Bakhtin, a autora afirma que, mudando os interlocutores, muda-se o discurso, logo, mudam-se também a composição e o estilo do gênero, além disso, a DC e o discurso científico pertencem a campos distintos:

\begin{abstract}
Se é constitutivo do discurso estar voltado para o destinatário, e se esse destinatário se concebe diferentemente em diferentes condições de produção, tal como ocorre com os destinatários do discurso científico e com os do discurso da divulgação científica, é lícito concluirrmos que estamos diante de dois gêneros discursivos distintos, e mais, colocados em funcionamento em campo discursivos distintos (2001, p. 94).
\end{abstract}

Abordamos alguns trabalhos já realizados em DC com o objetivo de situar o campo dos estudos nesta área e assumirmos uma posição em relação aquilo que chamaremos de DC.

\title{
2.3 Caminhos da divulgação científica no Brasil
}

Aqui pretendemos apresentar, de modo bem geral, um histórico das publicações de divulgação científica no Brasil ${ }^{9}$. Pouco se conhece sobre a história da DC no Brasil, chega-se mesmo a imaginar que ela não existiu ou foi insignificante durante o período histórico brasileiro e que só após a década de 80 se poderia falar em divulgação científica propriamente dita, essa visão é parcial e demonstra um certo desconhecimento da evolução da ciência e de sua difusão no país.

No Brasil dos séculos XVI, XVII e XVIII, uma colônia portuguesa de exploração e com uma população de iletrados, atividades científicas e mesmo de difusão das idéias modernas eram inexistentes, além disso era proibida a impressão de livros na colônia. As raras ações do governo português no Brasil, ligada à ciência, estavam quase sempre restritas às necessidades técnicas ou militares de interesse imediato.

No final do século XVIII e início do século XIX, muitos brasileiros que haviam ido para a Europa começaram a retornar ao país e contribuíram para uma difusão lenta das novas concepções científicas. A primeira manifestação mais consistente da atividade de divulgação no Brasil viria a ocorrer no início

\footnotetext{
${ }^{9}$ Muitas iniciativas na área de divulgação científica foram deixadas de fora, como: a criação de programas de $\mathrm{Tv}$ e rádio, de institutos, bem como, exposições, conferências, museus, boletins informativos, seção em jornais diários etc. Para os interessados recomendamos as obras de AZEVEDO, F (1995) e MASSARANI, L. e al (2002). Nesta seção nos concentramos no surgimento de revistas de DC.
} 
do século XIX com a chegada da corte portuguesa no país, a proibição de imprimir foi suspensa pouco depois surgiram as primeiras instituições de ensino superior. Com a criação da imprensa Régia, 1810, textos e manuais voltados para a educação científica, embora em número reduzido começaram a ser publicados. "Nesse período os primeiros jornais como A Gazeta do Rio de Janeiro, O Patriota e o Correio Braziliense publicaram artigos e notícias relacionados à ciência." (Moreira e Massarani, 2002, p.45).

$\mathrm{Na}$ segunda metade do século $\mathrm{XIX}$, as atividades de divulgação se intensificaram em todo o mundo devido à segunda revolução industrial. No Brasil, o que poderia chamar de pesquisa científica no país era ainda restrita a pouquíssimas pessoas. "do ponto de vista da divulgação da ciência nos periódicos, a análise do catálogo da Biblioteca Nacional mostra que, ao longo de todo o século, foram criados cerca de 7.000 periódicos no Brasil dos quais aproximadamente 300 relacionados de alguma forma à ciência." (Moreira e Massarani, 2002 p. 46).

Em 1857, foi criada a Revista Brazileira - Jornal de Sciencias, Letras e Artes, que publicava tanto artigos elaborados pelos seus criadores quanto artigos extraídos de publicações nacionais e estrangeiras. A partir de 1874, com a chegada do telégrafo, os jornais começaram a divulgar notícias mais atualizadas sobre as novas teorias ou descobertas.

Em 1876, foi lançada a Revista do Rio de Janeiro. Segundo seu primeiro editorial "um dos meios mais eficazes de favorecer a instrução e o progresso, e ao mesmo tempo prestar valioso serviço ao país, que tem tudo a ganhar com a difusão das luzes, é vulgarizar as ciências, letras, artes, agricultura, comércio e indústria". ${ }^{10}$

Outra revista, criada em 1881, foi Ciência para o povo, uma publicação semanal com a maioria dos artigos sobre ciência, em particular saúde e comportamento. Nos anos 1886-1891, circulou a Revista do Observatório, editada mensalmente pelo Imperial Observatório do Rio de Janeiro, tinha em sua comissão de redação cientistas conhecidos. Segundo Moreira e Massarani (2002, p. 48), "A revista trazia ilustrações e uma disposição dos textos mais

\footnotetext{
${ }^{10}$ Revista do Rio de janeiro, $\mathrm{n}^{\mathrm{o}}$ 1, 1876. (apud Moreira e Massarani, 2002, p.47).
} 
moderna, distribuída em colunas, ao contrário da Revista do Rio de Janeiro e da Revista Brazileira, que tinham a aparência de livro." No final do século XIX, as atividades de divulgação científica sofreram um certo refluxo, diminuiu o número de artigos e revistas referentes à divulgação. "Essa redução relativa está correlacionada com a diminuição similar que ocorreu nas atividades de divulgação no contexto internacional." (Moreira e Massarani, 2002 p.52).

No início do século $\mathrm{XX}$, houve tentativas de consolidar as pesquisas científicas no país. Um marco determinante nesse período foi a criação, em 1916, da Sociedade Brasileira de Ciências, que se transformaria depois na Academia Brasileira de Ciência $(A B C)$. Entre as várias publicações que se dedicavam à divulgação científica, nesse período, podemos citar Rádio Revista de divulgação científica geral especialmente consagrada à radiocultura, que era órgão da Rádio Sociedade do Rio de Janeiro, lançada em 1923. Em 1926, a Radio Sociedade do RJ começou a publicar outra revista bimestral de radiocultura, Electron. As revistas traziam resumo de cursos e palestras, temas técnicos de radiotelefonia, artigos de interesse da comunidade científica.

A revista Sciencia e Educação foi iniciada, em 1929, segundo seu primeiro editoral o objetivo da revista era divulgação científica articulada com a questão educacional. Alguns boletins e revistas de caráter científico ou técnico também deram espaço para a DC como ocorreu com a Revista da Sociedade Brasileira de Ciências, de 1917, e outras publicações da ABC. Eu sei tudo, que se apresenta como um resumo das principais revistas do mundo, constitui um exemplo de revista de variedades que continha notícias relacionadas à ciência, foi criada, em 1917, pela Editora Americana e durou muitos anos.

Ao longo de toda a década de 20, "jornais diário, em maior ou menor grau, mas sem cobertura sistemática, abriram espaço para notícias relacionadas à ciência," (Moreira e Massarani, 2002 p. 55).

Nos anos 40, começou a atuar o médico, microbiologista, economista e divulgador da ciência José Reis, professor da Universidade de São Paulo, ele é considerado um dos pioneiros do jornalismo científico no Brasil. José Reis foi um dos fundadores, em 1948, da Sociedade Brasileira para o Progresso da Ciência (SBPC), entidade que tem entre seus principais objetivos o de contribuir para a popularização da ciência. Em 1949, foi criada a revista Ciência 
e Cultura, idealizada por José Reis e pelo grupo de pesquisadores que fundaram a SBPC.

No início dos anos 50, discussões sobre o uso militar e civil da energia nuclear contribuiu para o interesse público generalizado pelas ciências físicas, revistas de interesse geral como O Cruzeiro e Manchete, trouxeram muitas matérias sobre esse área. Nos anos 70, as reuniões anuais da Sociedade Brasileira para o Progresso da Ciência, ganharam grande repercussão pública e atraíram cientistas, professores, estudantes etc. A divulgação científica, depois de um período tímido devido ao início da ditadura militar na década de 60 , voltou a ser considerada como significativa por uma parcela da comunidade científica.

A partir dos anos 80, novas atividades de divulgação começaram a surgir, principalmente nas páginas dos jornais diários, nos quais seções de ciência foram criadas. Em 1982, foi criada, no Rio de Janeiro, a revista Ciência Hoje, da SBPC:

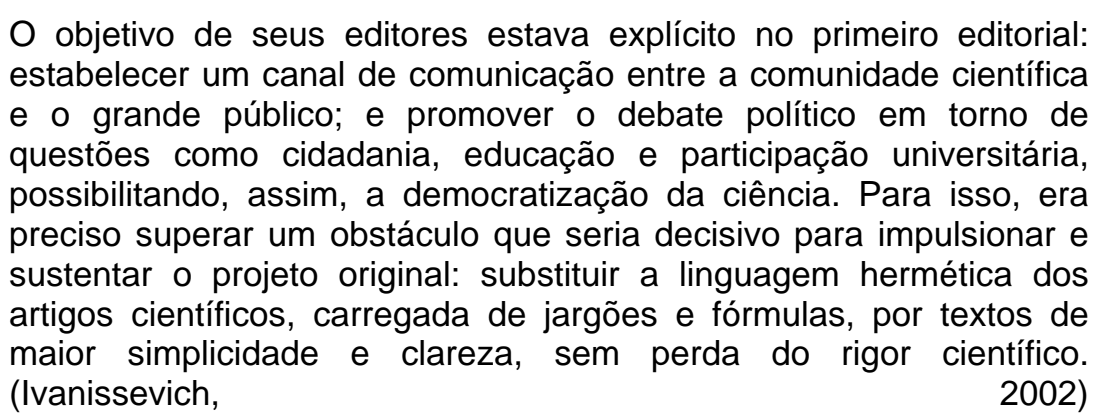

A revista chegou a atingir 70.000 exemplares na década de 80 . Tão importante quanto ela foi outra iniciativa dela emanada a Ciência Hoje das Crianças, criada em 1986.

Nas trilhas da Ciência Hoje, surgiram outras revistas ligadas a empresas privadas, como Superinteressante, lançada em 1987 pelo grupo Abril e Globo Ciência (hoje Galileu), criada em 1990 pela editora Globo. Elas são vendidas em bancas em todo o país e alcançam milhares de leitores.

A partir da experiência inicial com um boletim informativo, criado em 1995, surge em outubro de 1999, a revista Pesquisa Fapesp, de responsabilidade da Fundação de Amparo à Pesquisa do Estado de São Paulo (FAPESP) 
Em julho de 2002, começou a ser publicada a versão brasileira da Scientific American, o que demonstra o movimento de ampliação do interesse editorial do público sobre o tema. Além dela, houve o surgimento recente de revistas de divulgação de diversas áreas do conhecimento: História, Psicologia, Filosofia, Psicanálise, etc.

Muitos foram os periódicos de DC lançados a partir do final do século XIX e durante todo o século XX. Aqui nos concentraremos em 5 (cinco) publicações, a saber:

\begin{tabular}{|c|c|}
\hline ANO DE PUBLICAÇÃO & REVISTAS \\
\hline 1982 & Ciência Hoje \\
\hline 1987 & Superinteressante \\
\hline 1990 & Galileu $^{11}$ \\
\hline $1999^{12}$ & Pesquisa FAPESP \\
\hline 2002 & Scientific American Bra \\
\hline
\end{tabular}

Quando decidimos trabalhar com DC tornou-se indispensável abordarmos questões relativas à ciência e, mais especificamente, à DC. Com esse capítulo procuramos abordar as questões que foram surgindo no decorrer do trabalho.

É importante ressaltar a diferença entre discurso científico e DC. O discurso científico é produzido por uma comunidade de especialista que tem por objetivo atingir seus pares. O discurso científico destina-se a um público específico e tem sua circulação restrita ao campo científico. Já a DC tem por objetivo divulgar conhecimento científico a um público amplo, de não especialistas, a idéia não é formar especialista, mas transmitir, compartilhar saberes.

\footnotetext{
${ }^{11}$ Foi publicada em 1990 com o nome de Globo Ciência, posteriormente o nome da revista foi alterado para Galileu.

${ }^{12}$ O boletim Notícias Fapesp, que deu origem à revista Pesquisa FAPESP é de 1995.
} 
Abordamos, ainda, nesse capítulo, os trabalhos de duas lingüistas sobre a DC, a primeira é Authier-Revuz para quem a DC é a reformulação do discurso científico. A outra é Zamboni que defende a idéia de que o discurso de DC é formulação efetiva de um outro discurso e não reformulação, além disso, para a autora a DC é um gênero particular do discurso. Nesta pesquisa, estamos de acordo com Zamboni em um ponto, abordamos a DC como um processo de formulação de um discurso e não apenas de reformulação, visto que, a DC está sujeita a condições de produção específicas diferentes daquelas que ocorrem no discurso científico. No entanto, discordamos da autora quando ela diz que a DC é um gênero de discurso.

A DC é entendida como uma prática discursiva que circula por diferentes campos $^{13}$ (o científico, o jornalístico, o pedagógico) e assume diferentes gêneros (artigo, reportagem, aula, história em quadrinhos etc.). Em conformidade com Maingueneau (2000), entendemos por prática discursiva o funcionamento discursivo que leva em conta o conteúdo, o modo de organização e a rede de circulação. O gênero, nesse caso, está diretamente relacionado com o campo ao qual a divulgação científica está associada.

Por fim, fazemos um panorama histórico da DC no Brasil, o objetivo é mostrar o movimento em torno da DC no Brasil que aos poucos se tornou cada vez mais popular.

\footnotetext{
${ }^{13}$ Ou tipo de discurso como concebe Maingueneau, ou ainda, formação discursiva.
} 


\section{Cap. III}

\section{GÊNERO DE DISCURSO: A CONSTITUIÇÃO DOS SENTIDOS EM TEXTOS DE DIVULGAÇÃO CIENTÍFICA}

Iniciaremos a análise do nosso corpus abordando uma questão que se mostra extremamente importante na constituição dos sentidos em textos de DC ou em qualquer texto: o gênero de discurso.

A seleção temática do corpus pôs em evidência alguns aspectos do funcionamento discursivo da DC em revistas especializadas. O gênero se mostrou fator primordial na caracterização dos textos de modo que os outros aspectos abordados nos próximos capítulos têm uma relação direta com o gênero de discurso adotado. Segue uma tabela com os textos que fazem parte do corpus analisado e seus respectivos gêneros:

Sobre Clonagem Humana

\begin{tabular}{|c|c|c|c|}
\hline Revista & Ano & Título & Gênero \\
\hline Superinteressante & Jul/2001 & Homens em série & Reportagem \\
\hline Galileu & Out/2001 & $\begin{array}{c}\text { A um passo da } \\
\text { clonagem humana }\end{array}$ & Reportagem \\
\hline Pesquisa FAPESP & Mar/2004 & $\begin{array}{c}\text { Lei Polêmica: } \\
\text { projeto restringe } \\
\text { poder da CTNBio, } \\
\text { proíbe clonagem } \\
\text { terapêutica e } \\
\text { mobiliza cientistas }\end{array}$ & Reportagem \\
\hline $\begin{array}{c}\text { Scientific American } \\
\text { Brasil }\end{array}$ & Jul/2003 & $\begin{array}{l}\text { Prós e contras da } \\
\text { clonagem humana }\end{array}$ & Artigo \\
\hline Ciência Hoje & Out/2001 & $\begin{array}{l}\text { A técnica de } \\
\text { clonagem de } \\
\text { mamíferos }\end{array}$ & Artigo \\
\hline
\end{tabular}

Sobre Vacinas

\begin{tabular}{|c|c|c|c|}
\hline Revista & Ano & Título & Gênero \\
\hline Superinteressante & Fev/2001 & $\begin{array}{c}\text { Vacinas fazem bem } \\
\text { ou mal? }\end{array}$ & Reportagem \\
\hline Galileu & Set/2003 & $\begin{array}{c}\text { AlDS: imunes por } \\
\text { natureza }\end{array}$ & Reportagem \\
\hline Pesquisa FAPESP & Nov/2002 & $\begin{array}{c}\text { O alvo é a saúde } \\
\text { humana }\end{array}$ & Reportagem \\
\hline $\begin{array}{c}\text { Scientific American } \\
\text { Brasil }\end{array}$ & Set/2002 & $\begin{array}{c}\text { - AlDS: a grande } \\
\text { batalha da vacina }\end{array}$ & Reportagem \\
\hline
\end{tabular}




\begin{tabular}{|c|c|c|c|}
\hline & & $\begin{array}{l}\text { Como está o } \\
\text { Brasil em } \\
\text { relação à } \\
\text { vacina }\end{array}$ & Artigo \\
\hline Ciência Hoje & Out/1999 & $\begin{array}{c}\text { Vacina genética } \\
\text { contra tuberculose }\end{array}$ & Reportagem \\
\hline
\end{tabular}

Com o intuito de analisar os efeitos de sentidos produzidos pelos diferentes gêneros de discurso ligados a determinado campo ${ }^{14}$ ou tipo de discurso, estruturamos esse capítulo do seguinte modo: separamos as seções por gênero. Na seção reportagem, analisamos uma de cada periódico. $\mathrm{Na}$ seção artigo, analisamos os três textos encontrados.

\subsection{A DC na reportagem}

De acordo com o manual de redação da Folha de S. Paulo, reportagem é o relato do acontecimento importante, feito pelo jornalista que tenha estado no local em que o fato ocorreu ou tenha apurado as informações relativas a ele. A reportagem é o núcleo essencial do jornalismo. Ela deve conter: a descrição do fato todas as versões das partes envolvidas e, se possível, a opinião de especialistas (Manual geral de redação, 1987, p. 122). Acredito que no caso de reportagem de DC a voz do especialista é obrigatória.

Desse modo, o gênero reportagem é definido como informativo de caráter objetivo, a função da reportagem é tomar como tema um acontecimento e discuti-lo por meio de investigações e da exposição das fontes no texto.

\section{- Superinteressante}

Essa reportagem foi extraída da revista Superinteressante, de julho de 2001 contém antetítulo ("ciência"), título ("Homens em série"), páginas com muitas ilustrações coloridas e esquemas. Como em toda revista, principalmente nas de natureza comercial, o assunto tratado deve chamar a atenção do leitor, deve despertar seu interesse. No momento em que o texto aparece (em 2001), a clonagem humana era o tema mais explorado pela mídia e o que despertava

\footnotetext{
14 Essa noção de campo foi tomada de Bourdieu (2004), segundo o autor "para compreender uma produção cultural (literatura, ciência etc) não basta referir-se ao conteúdo textual dessa produção, tampouco referir-se ao contexto social contentando-se em estabelecer uma relação direta entre o texto e o contexto(...), entre esses dois pólos, muito distanciados, (...) existe um universo intermediário que chamo campo literário, artístico, jurídico ou científico, isto é, o universo no qual estão inseridos os agentes e as instituições que produzem, reproduzem ou difundem a arte, a literatura ou a ciência. Esse universo é um mundo social como os outros, mas que obedece a leis sociais mais ou menos específicas." ( Bourdieu, 2004, p. 20)
} 
maior interesse do público em geral. Ao explorar um tema de interesse geral aliado a recursos discursivos que tornam agradável e fácil o acesso à informação por um público leigo em matéria de ciência, a revista procura assegurar seu sucesso comercial.

Uma característica marcante das reportagens é a fragmentação através de infográficos e boxes. Os infográficos, desenhos esquemáticos, explicam passo a passo o procedimento de clonagem o que atrai a atenção de um outro tipo de público, o que lê apenas desenhos, um público jovem, habituado com velocidade na obtenção das informações. Nessa reportagem, o infográfico, cujo título é "operação clonagem humana: a técnica usada é a mesma que trouxe Dolly ao mundo", informa, por meio de desenhos, como seria feita a clonagem humana.

Um outro recurso recorrente nas reportagens é a utilização de boxes. 0 box é um recurso editorial em que um texto aparece entre fios, sempre em associação íntima com outro texto, mais longo. Pode ser uma biografia, um diálogo, uma nota de redação, um comentário etc. O Box intitulado "Era só o que faltava: a clonagem pode reforçar o aparecimento de uma nova modalidade de eugenia" aparece em forma de comentário. O jornalista comenta o tema sobre um ponto de vista não abordado pelos especialistas no interior da reportagem.

A linguagem na reportagem é objetiva, simples, clara, com expressões do cotidiano do leitor:

Mesmo assim já há quem esteja tentando clonar gente. (Superinteressante, jul/2001, p. 63)

A técnica usada na tentativa de produzir clones de gente... (Superinteressante, jul/2001, p. 64)

Os períodos são curtos para facilitar o entendimento do texto:

Todas as células possuem uma duplicata de cada gene. Em algumas delas, só aqueles vindos da mãe funcionam. Em outras, apenas as cópias recebidas do pai. (Superinteressante, jul/2001, p. 66)

$A$ criança será fisicamente idêntica àquela que morreu. Mas nascerá numa outra época, passará por experiências distintas, terá outra personalidade. Enfim, será outra pessoa. (Superinteressante, jul/2001, p. 66) 
O texto possui um grande número de citações em discurso direto de especialista. Recurso comum em reportagem de DC, visto que o enunciadorjornalista é apenas um mediador, a voz da ciência vem dos especialistas citados. $O$ enunciador-jornalista se abstém de emitir julgamento, as opiniões vêm dos especialistas. Trataremos com mais detalhes do discurso relatado no capítulo V.

- Galileu

A reportagem seguinte é da revista Galileu publicada em outubro de 2001 e recebe a denominação de "Dossiê". Essa reportagem segue os moldes da anterior (muitas ilustrações, esquemas, desenhos, boxes, etc). Ela foi segmentada em seções temáticas: "O que é", "Quem é contra", "Célulastronco", "Fertilização", "O que falta fazer". Ao longo da reportagem existe uma cronologia com a evolução da técnica de clonagem.

Em "O que é", temos o seguinte subtítulo "uma proeza esperada: Réplica a partir de célula adulta de mamíferos só exige vontade e coragem". Aqui o processo de clonagem é explicado passo a passo e mostra como exemplo o processo de clonagem da ovelha Dolly. No final da página o infográfico trata de resumir esquematicamente o processo de clonagem da ovelha.

Na seção "Quem é contra" o título é "O medo e a fascinação". O jornalista apresenta as opiniões divergentes sobre o assunto cedendo lugar a várias vozes de campos distintos. Tem-se a opinião dos governos (campo político), das igrejas (campo religioso) e dos cientistas (campo científico). Há um Box com o título "Os opositores", no qual informa quem são esse opositores (os governos, as igrejas e os cientistas) e seus argumentos.

A seguinte "células-tronco" vem com o título "As 1001 aplicações e o impasse: mesmo com evidente utilidade terapêutica, pesquisa sofre restrições". Nesta seção, discutem-se as possibilidades da clonagem de embriões para retirada das células-tronco. Nesta seção, temos um debate sobre os prós e contras da clonagem terapêutica. Encontramos também um infográfico "Fábrica de órgãos", que mostra como são obtidas as células tronco a partir de embriões humanos, e um Box "tratamentos que podem surgir", que faz uma relação das doenças que podem ser curadas por injeções de células tronco. 
Em "Fertilização" a discussão é sobre a clonagem reprodutiva, casais que não podem ter filhos se valeriam da clonagem para alcançarem o sonho da paternidade. O texto inicia-se lembrando da experiência que resultou no nascimento do primeiro bebê de proveta da história em 1978, na época houve uma grande mobilização (a favor e contra) como ocorre hoje com a clonagem humana. Aqui temos um infográfico com o título "Sem espermatozóide" mostrando como a pesquisadora obteve um embrião de rato sem uso de espermatozóide, usando um óvulo e uma célula comum.

$\mathrm{Na}$ última parte do dossiê, "O que falta fazer", são apresentados os cientistas que se dedicam à clonagem humana, ignorando os obstáculos técnicos e éticos. Temos dois boxes, um "A seita das cópias alienígenas" que informa sobre a seita dos raelianos e sua intenção de clonar seres humanos, já o segundo "O que resta explicar", faz uma lista dos problemas que apresenta a clonagem reprodutiva. Por fim, há um Box disposto no canto esquerdo ao longo de toda a reportagem, nele aparece a cronologia da evolução das técnicas de clonagem (de 1902 até 2001).

Uma reportagem segmentada dessa maneira, por seções, é capaz de atingir leitores com interesses diversos. Nesse sentido, o leitor não necessita ler o dossiê completo, ele pode ir à seção que mais the interessar. Com a segmentação o leitor lê apenas aquilo que Ihe interessa. A linguagem também é cotidiana e objetiva, com períodos curtos.

Será que a clonagem levará à produção de gente em massa, à comercialização de bebês ou a uma "raça de elite", à la Hitler? (Galileu, out,2001)

No resto dos organismos, porém, nenhuma célula do corpo é capaz de gerar um novo ser. Assim, a reprodução tem que ser feita por meio da fecundação, o que exige células muito especiais. São o óvulo e o espermatozóide. (Galileu, out/2001)

Aqui verificamos também a presença de um grande número de citações. As vozes dos especialistas de diferentes campos (científico, político, religioso, etc) e do público em geral se alternam ao longo do texto.

\section{- Pesquisa FAPESP}

A reportagem da revista Pesquisa FAPESP foi publicada em março de 2004 com o título "Lei Polêmica: projeto restrínge poder da CTNBio, proíbe clonagem terapêutica e mobiliza cientistas". 
Aqui há ausência das cores e dos desenhos, temos duas fotos de embriões, dois boxes e um infográfico, a fragmentação quase não existe. $O$ infográfico mostra, através de uma seqüência, pesquisadores retirando o núcleo de celular de um óvulo e em seguida injetando o material genético de célula adulta para obter células-tronco. Quanto aos boxes, o primeiro "células progenitoras" traz informações sobre as células tronco e sobre a clonagem terapêutica, o segundo "carta da FAPESP aos senadores" reproduz a carta enviada aos senadores pelo então presidente da FAPESP Carlos Vogt informando que a Lei de Biossegurança representa um obstáculo à pesquisa científica e tecnológica.

Nesta reportagem, a discussão gira em torno do projeto de lei de Biossegurança, que proíbe a clonagem terapêutica com células-tronco embrionárias. O primeiro parágrafo da reportagem apresenta o número da lei de Biossegurança ( $n^{\circ}$ 2.401, de 2003) e um resumo do texto aprovado na câmara pelos deputados. A reportagem da pesquisa FAPESP é extremamente informativa, não há qualquer esforço de facilitação, ou tentativa de captação de um leitor que não esteja interessado em obter informações sobre o projeto de lei. A reportagem mostra as controvérsias existentes no texto do projeto.

O enfoque da reportagem é política científica e tecnológica, o enunciador-jornalista se dirige à entidades científicas, juristas, pesquisadores, representantes de associações científicas.

A linguagem é bastante objetiva. Existe um grande número de períodos longos, o que exige um leitor com maior capacidade de compreensão e interpretação.

Por meio da clonagem terapêutica ou transferência de núcleo, detalha Mayana, é possível transferir um núcleo de uma célula de uma pessoa - da pele, por exemplo - para um óvulo sem núcleo, esse novo óvulo, em tese, se tornaria capaz de produzir qualquer tecido daquela pessoa em laboratório, sem risco de rejeição. (Pesquisa FAPESP, mar/2004, p. 18)

A bancada evangélica na Câmara, formada por 55 deputados, chegou a ameaçar votar contra o projeto caso não fosse vetada a manipulação de embriões humanos para fim de clonagem terapêutica, prevista no relatório de Rebelo. (Pesquisa FAPESP, $\mathrm{mar} / 2004$, p. 18)

- Ciência Hoje 
A reportagem da Ciência Hoje é "Vacina genética contra tuberculose", foi publicada em outubro de 1999. O texto informa o número de vítimas da tuberculose no mundo e descreve $o$ trabalho de pesquisadores que tentam desenvolver uma vacina genética contra a tuberculose mais eficiente que a BCG.

A reportagem possui um infográfico que descreve como a vacina de DNA foi obtida. Não temos boxes e o texto é pouco fragmentado. A exemplo da Pesquisa FAPESP, temos um número expressivo de períodos longos:

Os camundongos que receberam quatro doses da vacina durante três meses e foram posteriormente infectados com o bacilo da tuberculose registraram a presença de 0 a 1 mil bactérias por grama de tecido, número excelente quando comparado ao do grupo de animaiscontrole, que não recebeu a vacina (até 1,2 milhão da bactéria por grama de tecido). (Ciência Hoje, out/1999, p. 46)

A vacina de DNA permitiria evitar o estabelecimento da tuberculose, eliminar a infecção causada pelo bacilo e curar casos crônicos ou mesmo aqueles em que a doença já está disseminada. (Ciência Hoje, out/1999, p. 46)

\section{- Scientific American Brasil}

O título da reportagem é "AIDS: a grande batalha da vacina" e foi publicada em setembro de 2002. O texto fala sobre as pesquisas que estão sendo feitas na busca de uma vacina eficiente contra a AIDS. A reportagem possui desenhos, fotos, boxes. Existe um infográfico ocupando uma página inteira.

A linguagem é objetiva, informativa, impessoal. Voltam a aparecer os períodos curtos.

Com qualquer tipo de droga, os experimentos da terceira fase são dispendiosos e difíceis de realizar. $E$ os experimentos relativos à aids o são ainda mais. (Scientific American Brasil, set/2002, p. 31)

Outro possível obstáculo é a variedade de subtipos de HIV, que afetam diferentes áreas do mundo. Há cinco grandes subtipos, batizados com letras maiúsculas que vão de A a Z. (Scientific American Brasil, set/2002, p. 31)

Analisando as reportagens nas cinco publicações verificamos que:

i) $O$ enunciador mediador é um jornalista, o que não chega a ser uma surpresa já que toda reportagem é obrigatoriamente escrita por um jornalista. 
ii) As reportagens da Galileu, Superinteressante, e Scientific American Brasil, apresentam pontos em comum: informatividade, objetividade, isto é, livre de opinião pessoal, boxes, segmentação, citações de especialistas, linguagem simples com períodos curtos.

iii) As reportagens da Pesquisa FAPESP e Ciência Hoje além de possuírem objetividade, informatividade e citações de especialistas, apresentaram características um pouco diferentes das encontradas nas outras revistas. A segmentação é bem menor, quase não existem boxes ou infográficos, há ausência de desenhos e de cores vibrantes. Os períodos nessas publicações são longos, com muita subordinação.

Passemos agora para a análise dos artigos de nosso corpus.

\subsection{A DC no artigo}

O artigo é um gênero jornalístico assinado, que traz a interpretação, análise ou opinião do articulista sobre um fato, assunto ou tema de relevância. Segundo o "Manual geral de redação da Folha de S. Paulo", o artigo é um "texto de interpretação ou opinião do autor. Deve ser sempre assinado. Pode ser escrito na primeira pessoa." (1987, p. 149).

Entretanto, o artigo não é um gênero exclusivamente jornalístico, no meio acadêmico é muito comum especialistas escreverem artigos científicos para publicação em revistas especializadas ou de DC.

\section{- Ciência Hoje}

O primeiro artigo analisado foi extraído da revista Ciência Hoje cuja edição é de responsabilidade da Sociedade Brasileira para o Progresso da Ciência. Publicado em outubro de 2001, ele vem assinado por Franklin David Rumjanek do Departamento de Bioquímica Médica da UFRJ. Visualmente, destacam-se o antetítulo (genética), o título ("A técnica de clonagem em mamíferos") que ocupa duas páginas e logo abaixo, como epígrafe, um provérbio medieval (em latim com tradução para o português em seguida), 1 Box, e alguns desenhos (hélice de DNA, mulher grávida, um feto) em tons opacos, nada de cores, de ilustrações chamativas.

Logo na primeira página, à esquerda, existe um resumo dando conta do conteúdo das próximas páginas, seguido da referência autoral e institucional. 
$\mathrm{Na}$ última página encontram-se as "sugestões para leitura" (bibliografia sobre o assunto). Embora semelhante, estruturalmente, a um artigo acadêmico (resumo, autoria e vínculo institucional, texto, bibliografia), este texto possui especificidades textuais e discursivas próprias de suas condições de produção. Como nos diz Maingueneau "A cada gênero associam-se momentos e lugares de enunciação específicos e um ritual apropriado" (Maingueneau, 1997 p. 36).

O artigo da Ciência Hoje se inicia com um breve histórico da clonagem de animais (a partir da década de 70) e, logo no quarto parágrafo, o autor adota uma atitude de cautela e prudência em relação à clonagem de seres humanos, atitude que percorre todo $o$ artigo:

...as dificuldades de ordem técnica e biológica ainda existentes
exigirão um trabalho científico bem mais minucioso antes que a
clonagem de vertebrados superiores possa ser considerada uma
prática rotineira.( Ciência Hoje, out/2001, p. 37)

O enunciador expressa sua opinião com base em dados científicos e de todo conhecimento especializado que possui. Ele se posiciona, se coloca como parte da comunidade científica. Não há portanto, citações de outros especialistas, o enunciador no máximo comenta o trabalho de algum colega. Temos um texto opinativo

Após explicar passo a passo como é realizada a clonagem, o enunciador faz considerações sobre os cuidados de ordem técnica que se deve ter com as células receptora e doadora. A linguagem é técnica, mas devido às explicações, é acessível ao público em geral.

- Scientific American Brasil

Os artigos seguintes foram publicados na revista Scientific American Brasil. O primeiro possui o título "Prós e contra da clonagem humana" e 0 segundo intitula-se "Como está o Brasil em relação à vacina".

O primeiro artigo é assinado por Volnei Garrafa, professor titular da Universidade de Brasília e apresenta a análise do especialista sobre o tema. Neste texto, assim como no anterior, prevalece a estrutura opinativa:

A ciência precisa seguir em frente no seu objetivo de antecipar-se ao futuro, com prudência e com controle democrático sobre suas aplicações praticas. (Scientific American Brasil, jul/2003, p. 57)

O enunciador-especialista posiciona-se diante dos fatos: 
defendo o discurso da liberdade para a criação no campo científico, com controle sobre suas aplicações práticas, sobre a tecnologia. (Scientific American Brasil, jul/2003, p. 57)

Mais uma vez, parece-me claro, o caminho está no equilíbrio. (Scientific American Brasil, jul/2003, p. 57)

Inclui-se na comunidade científica:

Cada vez mais pesquisadores passamos a defender a importância crescente da chamada "ética aplicada", que se materializou academicamente a partir dos anos $70 \mathrm{com}$ a criação da disciplina chamada Bioética. (Scientific American Brasil, jul/2003, p. 57, grifo meu)

O segundo artigo chama-se "Como está o Brasil em relação à vacina" foi publicado em setembro de 2002 e vem assinado por Esper Georges Kallás, infectologista e professor afiliado da Universidade Federal de São Paulo (Unifesp).

Esse artigo segue, basicamente, as mesmas características do anterior. Há o posicionamento por parte do enunciador, assumindo o papel de pesquisador:

O caminho a percorrer para a obtenção de uma vacina contra a aids parece ser bem diferente que o utilizado para obter as vacinas que usamos hoje contra as outras doenças. (Scientific American Brasil, set/2002, p. 35, grifo meu)

Nos dois artigos encontramos períodos curtos e linguagem próxima ao cotidiano do leitor.

Vacina de DNA, que é um pequeno fragmento de material genético contendo informações de um pedaço de HIV. (Scientific American Brasil, set/2002, p. 35, grifo meu)

Mas o sucesso não virá de imediato. Nesse campo da ciência, cada passo vem sendo dado lentamente. É preciso torcer e trabalhar para que eles sejam dados com freqüência maior, no caminho da obtenção da vacina. (Idem)

Dolly foi a conseqüência bem sucedida de 277 tentativas anteriores aberrantes. (Scientific American Brasil, set/2003, p. 56, grifo meu)

Trata-se, assim, não de fazer tudo aquilo que possa ser feito, mas, ao contrário, de fazer o que deve ser feito. Hoje diversos países detêm a tecnologia para a construção da bomba atômica. Nem por isso, depois da dolorosa lição de Hiroshima e Nagasaki, se imagina a possibilidade de ela voltar a ser acionada. (Idem, p. 57)

Em relação aos artigos analisados vale ressaltar algumas questões: 
i) os enunciadores são especialistas no tema tratado. Por isso, assumem o papel de detentores do conhecimento e transmissores legítimos desse saber;

ii) Em vista disso, o discurso relatado quase não aparece. E quando aparece é em número muito reduzido, normalmente apenas para comentar um trabalho desenvolvido por outro especialista;

iii) O texto é opinativo, o enunciador se posiciona diante dos fatos;

iv) No que diz respeito à linguagem e estrutura observamos algumas diferenças: No artigo publicado na Ciência Hoje notamos o uso de uma linguagem mais técnica com termos especializados, nos publicado na scientific American Brasil evita-se o uso de termos muito técnicos; a estrutura também diverge quando comparamos as publicações, na Ciência Hoje temos a presença de um resumo na primeira página e de bibliografia na última, o que não aparece na Scientific American Brasil. 


\section{Cap. IV \\ DIVULGAÇÃO CIENTÍFICA: \\ AS RELAÇÕES ENTRE ENUNCIADOR E CO-ENUNCIADOR}

No capítulo anterior, ao analisar o gênero de discurso, observamos que uma das categorias que diferenciou reportagem de artigo e determinou suas coerções foi justamente o enunciador, em vista disso, resolvemos dedicar um capítulo à relação enunciador/co-enunciador.

Este capítulo apresenta uma análise sobre a questão do enunciador, e a relação que ele estabelece com o seu co-enunciador (leitor). Cada discurso define o estatuto que o enunciador deve conferir-se e o que deve conferir a seu destinatário para legitimar seu dizer. Essa maneira de dizer específica vem a ser a cenografia (Maingueneau). Além da cenografia, este capítulo tratará também dos segmentos de natureza explicativa, essas entradas colocam de um lado, um detentor de um saber (enunciador), e de outro, um leitor que se supõe não conhecer um termo e precise de esclarecimento.

Vale observar que tanto o enunciador quanto o co-enunciador tratados aqui são os inscritos materialmente no texto, não abordaremos os coenunciadores reais, empíricos.

\subsection{A cenografia}

$\mathrm{Na}$ Análise do Discurso francesa, a noção de cena é constantemente utilizada para se referir à maneira pela qual o discurso constrói uma representação de sua própria situação de enunciação. Vimos que um coenunciador, em geral, não trata diretamente com o político ou com o científico, mas sim com gêneros de discurso particulares. Cada gênero de discurso define seus próprios papéis: na reportagem, trata-se de um "jornalista" dirigindo-se a um tipo de "leitor", no artigo trata-se de um "especialista" dirigindo-se a outro tipo "leitor". São esses leitores que analisaremos nessa seção.

De acordo com Maingueneau (2004b), leitor não se confrontará diretamente com o tipo de discurso (cena englobante), nem com o gênero de discurso (cena genérica), mas sim com uma cenografia. Os textos analisados, reportagens e artigos, se enquadram no que Maingueneau chama de "gêneros 
instituídos de modo 2", os textos são individuais, mas submetidos a alguns parâmetros próprios do gênero. Possuem cenografia preferencial, porém toleram cenografias originais.

Neste capítulo, tendo em mente a questão da cenografia proposta por Maingueneau, procuramos expor as relações existentes entre enunciador e coenunciador, evidenciando os diferentes tipos de co-enunciadores.

Na reportagem da Superinteressante "Homens em série" (julho, 2001), o leitor cai numa espécie de cilada, o enunciador cria uma cenografia que não é apenas de uma reportagem, inclui também uma espécie de narrativa ficcional. O próprio título conduz a essa interpretação:

Enquanto você lê essa reportagem, há alguém tentando clonar um ser humano em algum lugar do mundo. Na surdina. Provavelmente, o pesquisador responsável pela tarefa acaba de soltar um suspiro inquieto ao constatar que, mais uma vez, a experiência falhou.

E finaliza com expressão típica do gênero telenovela: "Aguardemos as cenas do próximo capítulo." Essa cenografia, presente no primeiro e no último parágrafo, não se mantém no interior da reportagem,${ }^{15}$ trata-se apenas de uma moldura para o texto. A cenografia construída neste texto tem por objetivo tornar a reportagem atrativa, interessante ao co-enunciador que ao iniciar a leitura sinta-se curioso e leia toda a reportagem. Essa cenografia faz referência a gêneros da mídia televisiva e do cinema que apontam para o universo cultural do co-enunciador .

Outro recurso usado, embora pouco recorrente nas reportagens, é o diálogo direto com o leitor. Observemos os exemplos a seguir retirados das revistas Superinteressante e Galileu.

Você deve estar acostumado a ouvir histórias sobre discriminação de raça, religião ou nacionalidade. (Superinteressante, jul/2001, p. 66, grifo meu)

Imagine um indivíduo com um fígado parcialmente comprometido. (Superinteressante, jul/2001, p. 66, grifo meu)

Se a sabedoria popular já recomendava ir com calma na hora de discutir assuntos como religião, política e futebol, use essa mesma prudência quando entrar num debate sobre clonagem humana. (Superinteressante, jul/2001, p. 67, grifo meu)

\footnotetext{
${ }^{15}$ No interior da reportagem temos um jornalista informando ao seu leitor, por meio das vozes dos especialistas, sobre a clonagem humana no mundo.
} 
Imagine: à medida que 0 embrião cresce, suas células se transformam para formar os diversos órgãos do corpo.... (Galileu, 2001, s/p, grifo meu)

As espantosas células-tronco, que podem se transformar em qualquer parte do corpo, abrem caminho para fabricar órgãos para transplantes e curas de muitas doenças. Se os seus neurônios não estão funcionando, por exemplo, as células-tronco talvez possam se instalar em seu cérebro, metamorfosear-se em neurônios novos e corrigir o problema. (Galileu, 2001, s/p, grifo meu )

O uso do "imagine", dos pronomes "seu" e "você" e do imperativo "use" inscrevem o leitor no texto e o inclui na discussão sobre a clonagem. Ao escrever um texto o enunciador tem em mente um determinado co-enunciador, ou seja, a reportagem é direcionada a um determinado público. Esse público leitor da revista precisa ser captado e, nesse sentido, a reportagem vale-se de vários recursos gráficos e de linguagem, para prender e manter a atenção do seu co-enunciador.

$\mathrm{Na}$ reportagem publicada na Scientific American Brasil cujo título é "AIDS: a grande batalha da vacina" (setembro, 2002), a cenografia é construída a partir de uma citação de um especialista:

"Estamos em uma época interessante para a pesquisa da AIDS", observa Gregg Gonsalves, diretor da associação de tratamento e prevenção Gay Men's Haelth Crisis, de Nova York, "acho que entramos agora no segundo ato". (Scientific American Brasil, set/2002, p. 30)

O tema é tratado em "atos" como em uma peça teatral. "No teatro, o primeiro ato serve para introduzir os personagens e apresentar uma situação. No segundo ato, o conflito aprofunda-se e tem início a ação propriamente dita", explica o enunciador. Após o comentário o enunciador fala sobre os estágios da pesquisa em vacina.

O primeiro ato da pesquisa da vacina a aids introduziu o HIV, um dos primeiros retrovírus a causar uma doença grave em seres humanos. (Scientific American Brasil, set/2002, p. 30)

$\mathrm{O}$ primeiro ato também trouxe a público a reação contra o HIV, a resposta do sistema imunológico do organismo, que consiste em anticorpus. (Scientific American Brasil, set/2002, p. 30)

E comentando o que viria a ser o segundo ato:

Quando a cortina se levanta para o segundo ato, o HIV ainda está no palco. Os resultados do primeiro teste em larga escala da vacina contra a aids devem estar prontos no final deste ano. (Scientific American Brasil, set/2002, p. 30) 
Iniciando desse modo, o enunciador cria uma expectativa no seu leitor. O co-enunciador espera pelos outros atos e pelo desfecho da cena, essa expectativa, no entanto, é frustrada. Temos mais uma vez referência ao universo cultural televisivo, cinematográfico. Durante o restante da reportagem encontram-se apenas informações sobre a infecção de AIDS pelo mundo e os laboratórios de pesquisas que estão trabalhando em vacinas contra o HIV. O desfecho fica suspenso já que até o momento os esforços se mostraram inúteis.

O texto da Pesquisa FAPESP "Lei polêmica" (Março, 2004) discute a política científica em torno da clonagem de embriões humanos e dos transgênicos. O enunciador informa ao seu co-enunciador sobre o projeto de lei de Biossegurança aprovado pelo congresso. Toda a reportagem gira em torno das discussões sobre o tal projeto:

...é polêmico em pelo menos dois aspectos: atribui a um conselho de ministros a palavra final sobre a comercialização de organismos geneticamente modificados e proíbe as pesquisas com células-tronco para fins terapêuticos. (Pesquisa FAPESP, mar/2004, p. 16)

Essas discussões são feitas pelos especialistas citados ao longo da reportagem e não pelo enunciador-autor da reportagem, nesse caso uma jornalista:

"É fundamental para o desenvolvimento nacional que as pesquisas oriundas das instituições públicas possam ser rapidamente incorporadas ao nosso setor produtivo, sob pena de a sociedade brasileira não poder usufruir dos investimentos em ciência e tecnologia no Brasil", dizem os representantes de 13 entidades científicas, entre elas a Academia Brasileira de Ciências, em carta encaminhada aos senadores no dia 18 de fevereiro. (Pesquisa FAPESP, mar/2004, p.16, grifo meu )

A comunidade científica reagiu também negativamente à proibição das pesquisas com células-tronco para fins terapêuticos. "Os textos do projeto de lei que tratam da pesquisa com células-tronco embrionárias são particularmente alarmantes quanto aos efeitos na saúde pública", afirma o documento elaborado pelas 13 entidades. "A terapia celular com células- tronco embrionárias pode representar a esperança no tratamento de mais de 5 milhões de pessoas, a maioria crianças e jovens. Não se trata de produzir embriões para esta finalidade, mas utilizar aqueles que são descartados em clínicas de fertilização." (Pesquisa FAPESP, mar/2004, p.18, grifo meu)

"O lbama não tem competência para essa análise. Eles são ecólogos e não biólogos moleculares. Prova disso é que o instituto pediu um levantamento socioeconômico da população estabelecida num raio de 3 quilômetros para que a Embrapa pudesse testar o plantio de 
feijão numa área de 10 metros quadrados", afirma Borem. (Pesquisa FAPESP, mar/2004, p.20 )

A cenografia aqui seria a da reportagem, gênero que acolhe os diferentes pontos de vista sobre um mesmo tema ou fato, mas também a de um seminário cujo tema é políticas científicas. O co-enunciador está contido na escolha do tema, ou seja, o tema legal incorpora a comunidade científica, mas também administradores públicos, lideranças do setor produtivo e o público em geral preocupado com as aplicações das pesquisas com células-tranco para curar doenças. Desse modo, podemos supor que o co-enunciador dessa reportagem é um leitor inserido nas discussões científicas e que possui um certo grau de conhecimento no assunto, embora não seja necessariamente um especialista.

Comentaremos agora dois casos diferentes dos verificados até 0 momento, trata-se de dois artigos. O primeiro publicado na Ciência Hoje e o segundo na Scientific American Brasil.

$\mathrm{Na}$ Ciência Hoje ${ }^{16}$, o enunciador é um especialista no assunto discutido trata-se de Franklin David Rumjanek do Departamento de Bioquímica Médica (UFRJ), e a relação que ele estabelece com o co-enunciador é a de detentor do conhecimento que está sendo transmitido e não mero porta-voz.

O artigo apresenta seções com informações bastante técnicas, com descrição das etapas da clonagem não como as reportagens fazem (com gráficos, desenhos etc), mas mediante a exposição de procedimentos científicos.

Os ovócitos, obtidos pela estimulação da ovulação com hormônios esteróides, são colhidos e transferidos a um meio de cultura, onde podem ou não ser fertilizado com espermatozóides. (Ciência Hoje, out/2001, p. 36)

Durante a enucleação, deve se ter um cuidado especial para que a micropipeta não penetre na membrana plasmática do ovócito. (Ciência Hoje, out/2001, p. 36)

Em seguida, também usando uma micropipeta, acrescenta-se o carioplasto da célula doadora. (Ciência Hoje, out/2001, p. 36)

Alternativamente, pode-se transplantar também a célula inteira contendo o núcleo que dará origem ao clone. (Ciência Hoje, out/2001, p. 36)

\footnotetext{
16 "A técnica de clonagem de mamíferos" (Outubro, 2001).
} 
Há no artigo recomendações sobre os cuidados com as células:

A célula receptora pode ser o ovócito ou o zigoto. O uso do primeiro apresenta algumas vantagens em relação ao uso do outro: o ovócito enucleado dá ao núcleo transplantado mais tempo para adaptar-se do que o zigoto. (Ciência Hoje, out/2001, p. 36)

Essas observações nos levam a caracterizar esse leitor como misto, que, se não especialista, pelo menos possui alguns conhecimentos na área, e a quem interessaria conhecimentos mais técnicos dos procedimentos científicos. Os co-enunciadores seriam, portanto, grande público, estudantes, pesquisadores de outras áreas.

No artigo da Scientific American Brasil "Prós e contra da clonagem humana" (julho, 2003) o enunciador, Volnei Garrafa, professor titular da UNB (Universidade de Brasília), membro titular da Comissão Nacional de Ética em Pesquisa do Ministério da Saúde (Conep), se mostra efetivamente. Em alguns trechos temos passagens em primeira pessoa:

Mais uma vez, parece-me claro, o caminho está no equilíbrio. (Scientific American Brasil, jul/2003, p. 57)

Resumindo, defendo o discurso da liberdade para a criação no campo científico, com controle sobre suas aplicações práticas, sobre a tecnologia. ((Scientific American Brasil, jul/2003, p. 57)

Esse enunciador é especialista no tema. Trata-se de um professor titular da Universidade de Brasília que é autoridade no assunto e, por essa razão, expõe sua opinião a respeito do tema. O leitor desse artigo não encontrará desenhos, boxes, esquemas ou qualquer outro recurso gráfico de captação. $O$ co-enunciador desse texto é um indivíduo interessado em discussões éticas e políticas sobre as descobertas científicas, em particular as polêmicas.

\subsection{A explicação}

O discurso de divulgação científica tem, entre outras, a função de explicar a ciência, visto que, o objetivo é divulgar a ciência para fora da comunidade científica. De acordo com Moirand (1999):

Considerar uma seqüência discursiva como explicativa supõe relacioná-la a seu contexto lingüístico, à situação de comunicação na qual ela se inscreve (Por que A explica? Por que B precisa de explicação? Como se decide que ele precisa de explicação?), e as suas condições sócio-históricas de produção. (Moirand, 1999, p.142). 
Na divulgação científica a explicação tem função didática: A explica qualquer coisa à $B$. Existe uma assimetria de conhecimento, A possui os saberes diferentes daqueles de $B$, estando em posição de transmitir esses saberes.

Segundo Moirand (1999, p. 145) a explicação possui uma situação triangular, A representando jornalista-mediador, B o grande público e S o discurso da ciência, assim:

\section{A explica à $\mathbf{B}$ que $\mathbf{S}$ diz que [X explica $\mathbf{Y}]$}

Lygia se refere a um fenômeno natural chamado imprinting, uma espécie de carimbo que certos genes recebem, dependendo da origem, materna ou paterna. (Superinteressante, jul/2001, p. 66)

Nesse trecho, o jornalista (A) explica ao leitor (B) que a especialista (S) diz que imprinting é uma espécie de carimbo.

Segundo Moirand (1999), em uma estrutura discursiva dialogal a presença da forma verbal "explicar" funciona como o sinal de um pedido ou oferta de explicação (você pode me explicar? Ou eu vou te explicar.). Em divulgação científica a presença do verbo "explicar" como introdutor não quer dizer que a seqüência discursiva seja uma explicação, a presença desse verbo tem uma acepção vasta e equivale a "dizer", para introduzir uma informação, uma descrição seguida da caracterização do especialista enunciador citado, é o que ocorre no exemplo abaixo, nele o "explicar" equivale a "dizer":

Para complicar a situação, mesmo quando o sistema imune de um infectado consegue sintetizar anticorpus bons, o HIV dá um jeito de se esquivar. "O vírus engana o sistema imune ao criar novas mutações em suas proteínas e ganhar uma aparência diferente para os anticorpos", explica o cientista Kenneth Roux, da Universidade Estadual da Flórida. (Galileu, set/2003, p.27)

A seqüência textual explicativa pode ser anunciada, desencadeada pelo verbo "explicar" ou por outras formulações. Analisando o corpus verificamos que as reformulações lexicais de natureza explicativa são marcadas pelo verbo ser, por parênteses, por conectivos como, "isto é", "em outros termos", etc. Nas reportagens o enunciador usa exemplos simples, do cotidiano, ao explicar os termos especializados. A reprodução sexuada é apresentada da seguinte maneira: 
Durante a fecundação, o óvulo e o espermatozóide se unem e somam os seus genes, de modo que a célula resultante passa a ter dois conjuntos de DNA. Daí para frente, ela se multiplica, dividindo-se sucessivamente, e se transforma num embrião. (Galileu, out/2001, $\mathrm{s} / \mathrm{p})$

\section{Outros exemplos de explicações em DC marcadas por:}

- Parênteses

Essa habilidade do HIV vem das duas proteínas que o recobrem, a gp 120 e a gp 41. Elas são revestidas de estruturas de carboidratos (moléculas de carbono, hidrogênio e oxigênio), o que as torna muito semelhante a proteínas humanas. (Galileu, set/2003, p.27)

Naquela época - conta o pesquisador - já se sabia que as vacinas chamadas BCG (Bacilo Calmette-Guérin) ... (Ciência Hoje, out/1999, p. 47)

...a resposta do sistema imunológico do organismo, que consiste em anticorpos (moléculas em forma de $\Upsilon$ que capturam invasores como os vírus e os eliminam), e células T citotóxicas ou fagócitos (glóbulos brancos encarregados de destruir células infectadas por vírus). (Scientific American Brasil, set/2002, p. 30)

O primeiro é o gene que tem a receita da produção de proteína hsp65 (hsp significa heat shock protein ou proteína de choque térmico, e 65 indica seu peso molecular (...)) (Pesquisa FAPESP, nov/2002, p. 40)

Foi com esse gene, integrado a um plasmídeo (fragmento de DNA em forma de anel), que Silva obteve os resultados preliminares da primeira vacina gênica contra tuberculose no mundo. (Pesquisa FAPESP, nov/2002, p. 41)

No Brasil, o experimento é feito com a vacina contra Haemophilus influenza (gripe). (Superinteressante, fev/2001, p. 43)

O médico Volnei Garrafa, especialista em bioética (campo da filosofia que relete sobre questões biológica). (Superinteressante, jul/2001, p. 42)

... e a vacina da companhia emprega a molécula em sua forma monomérica, isto é, aquela que tem apenas uma molécula. (Scientific Anerican Brasil, set/2002, p. 33)

Edward Jenner injeta a secreção das fístulas de uma vaca com varíola - ou seja, pus - em um menino. (Superinteressante, fev/2001, p. 42)

A segunda fase envolve centenas de pessoas e examina mais de perto a imunogenicidade da vacina, isto é, sua capacidade de introduzir uma resposta do sistema imunológico. (Superinteressante, fev/2001, p. 31)

Outra importante condição é que tais microorganismos não causem qualquer doença nas pessoas que vão receber a vacina, ou seja, que não seja patogênicos. (Superinteressante, fev/2001, p. 35)

Em geral, a célula usada para receber o material genético da célula doadora é um zigoto, ou seja, um ovo fertilizado por um espermatozóide. (Ciência Hoje, out/2001, p. 36) 
- Verbo "ser"

Uma das habilidades mais importantes da vacina estudada pelo grupo de Ribeirão Preto é agir diretamente sobre os macrófagos, que são células essenciais do sistema de defesa, que coordenam a ação de outras células, (Pesquisa FAPESP, nov/2002, p. 38)

O) termo clone (...), definido pelo próprio Webber é "uma colônia de organismos que, de modo assexuado (sem intervenção de sexo ) deriva de um só progenitor". (Ciência Hoje, out/2001, p. 35)

O carioplasto é o núcleo retirado da célula doadora, ainda rodeado por uma camada delgada de citoplasma e de membrana plasmática. (Ciência Hoje, out/2001, p. 36)

... a vacina de DNA, que é um pequeno fragmento de material genético... . (Scientific Anerican Brasil, set/2002, p. 35)

Encontramos igualmente reformulações semânticas (metáfora) que constroem no intradiscurso o paradigma designacional do termo que imaginamos ser o lugar de um provável pedido de esclarecimento.

toda bactéria nasce como um clone, ou seja, as filhas são cópias genéticas perfeitas das mães, que simplesmente duplicam o seu "corpo" e depois se dividem em duas. (Galileu, out/2001, s/p)

A primeira vacina em potencial a chegar à terceira fase consiste de gp 120, uma proteína que cobre o invólucro externo do HIV de saliências e que o vírus usa como "ganchos" para se prender e infectar as células. (Scientic American Brasil, set/2002, p.31)

O enunciador usa metáforas, "mãe" e "filhas", para facilitar o entendimento. O emprego das aspas em "corpo" e "gancho" é de proteção, indica que a palavra usada é apenas aproximativa. Os enunciados relatados em discurso direto são colocados entre aspas para marcar a alteridade, nesse caso há uma clara ruptura sintática entre o discurso que cita e o discurso citado. Nas palavras entre aspas, essa ruptura não existe, a palavra aspeada é ao mesmo tempo usada e mencionada, as aspas designam a linha de demarcação entre um discurso e seu exterior. De acordo com J. Authier (1981), as aspas possuem várias funções: aspas de diferenciação, destinadas a mostrar que nos colocamos além destes enunciados, irredutíveis as palavras empregadas; aspas de condescendências; aspas pedagógicas na vulgarização; aspas de proteção, para indicar que a palavra usada é apenas aproximativa; aspas de ênfase, etc.

O enunciador faz uma representação de seu leitor, desse modo, as aspas são colocadas para serem interpretadas por um destinatário. A relação 
de entendimento e de aproximação entre enunciador e co-enunciador nos remete ao fato de que nem o jornalista, nem o leitor são especialistas no assunto.

No artigo da Ciência Hoje "A técnica de clonagem de mamíferos" (Outubro, 2001), a linguagem empregada é mais técnica que a empregada nas reportagens analisadas. Embora acessível ao público em geral, o léxico parece ser mais especializado. O enunciador deste texto fala, por exemplo, em clonagem de "vertebrados superiores". Ao explicar como é realizada a clonagem o autor usa um vocabulário especializado. Termos como: zigoto, ovócito, enucleação, membrana plasmática, carioplasto, eletrofusão, meiose etc., aparecem com freqüência. Entretanto, tendo em vista que o texto dirige-se a um público não especializado, sempre ocorrem entradas de segmentos de natureza explicativa.

Analisando o material verificamos que:

I) as explicações são basicamente lexicais, ou seja, de termos. $O$ enunciador apresenta preocupação com a linguagem e para torná-la mais acessível, os termos considerados desconhecidos são explicados ao leitor;

II) as explicações de procedimentos (como é feita a clonagem ou como são feitas as vacinas de DNA, por exemplo) são apresentadas nos infográficos;

III) tanto nas reportagens quanto nos artigos há o predomínio de explicações de termos, demonstrando que a DC tem grande preocupação com o léxico. 


\section{Cap. V \\ DISCURSO RELATADO}

Levando em conta as considerações de Authier-Revuz sobre o discurso relatado apresentadas no primeiro capítulo desse trabalho, faremos aqui a análise do discurso relatado (DR) nas reportagens e artigos do nosso corpus. Segue abaixo uma tabela contendo informações sobre o texto.

- Clonagem Humana

\begin{tabular}{|c|c|c|c|}
\hline Revista & Ano & Título & Gênero \\
\hline Superinteressante & Jul/2001 & Homens em série & Reportagem \\
\hline Galileu & Out/2001 & $\begin{array}{c}\text { A um passo da } \\
\text { clonagem humana }\end{array}$ & Reportagem \\
\hline Pesquisa FAPESP & Mar/2004 & $\begin{array}{c}\text { Lei Polêmica: } \\
\text { projeto restringe } \\
\text { poder da CTNBio, } \\
\text { proíbe clonagem } \\
\text { terapêutica e } \\
\text { mobiliza cientistas }\end{array}$ & Reportagem \\
\hline Scientific American & Jul/2003 & $\begin{array}{c}\text { Prós e contras da } \\
\text { clonagem humana }\end{array}$ & Artigo \\
\hline Brasil & Out/2001 & $\begin{array}{c}\text { A técnica de } \\
\text { clonagem de } \\
\text { mamíferos }\end{array}$ & Artigo \\
\hline
\end{tabular}

- Vacinas

\begin{tabular}{|c|c|c|c|}
\hline Revista & Ano & Título & Gênero \\
\hline Superinteressante & Fev/2001 & $\begin{array}{c}\text { Vacinas fazem bem } \\
\text { ou mal? }\end{array}$ & Reportagem \\
\hline Galileu & Set/2003 & $\begin{array}{c}\text { AIDS: imunes por } \\
\text { natureza }\end{array}$ & Reportagem \\
\hline Pesquisa FAPESP & Nov/2002 & $\begin{array}{c}\text { O alvo é a saúde } \\
\text { humana }\end{array}$ & Reportagem \\
\hline $\begin{array}{c}\text { Scientific American } \\
\text { Brasil }\end{array}$ & Set/2002 & $\begin{array}{c}\text { AIDS: a grande } \\
\text { batalha da } \\
\text { vacina } \\
\text { Como está o } \\
\text { Brasil em } \\
\text { relação à } \\
\text { vacina }\end{array}$ & Reportagem \\
\hline Ciência Hoje & Out/1999 & $\begin{array}{c}\text { Vacina genética } \\
\text { contra tuberculose }\end{array}$ & Reportagem \\
\hline
\end{tabular}

\subsection{O DR nas reportagens}


Esta seção está organizada do seguinte modo: para cada periódico fizemos uma tabela das reportagens analisadas e em seguida fazemos a análise global do DR nas reportagens presentes naquela revista.

- Superinteressante

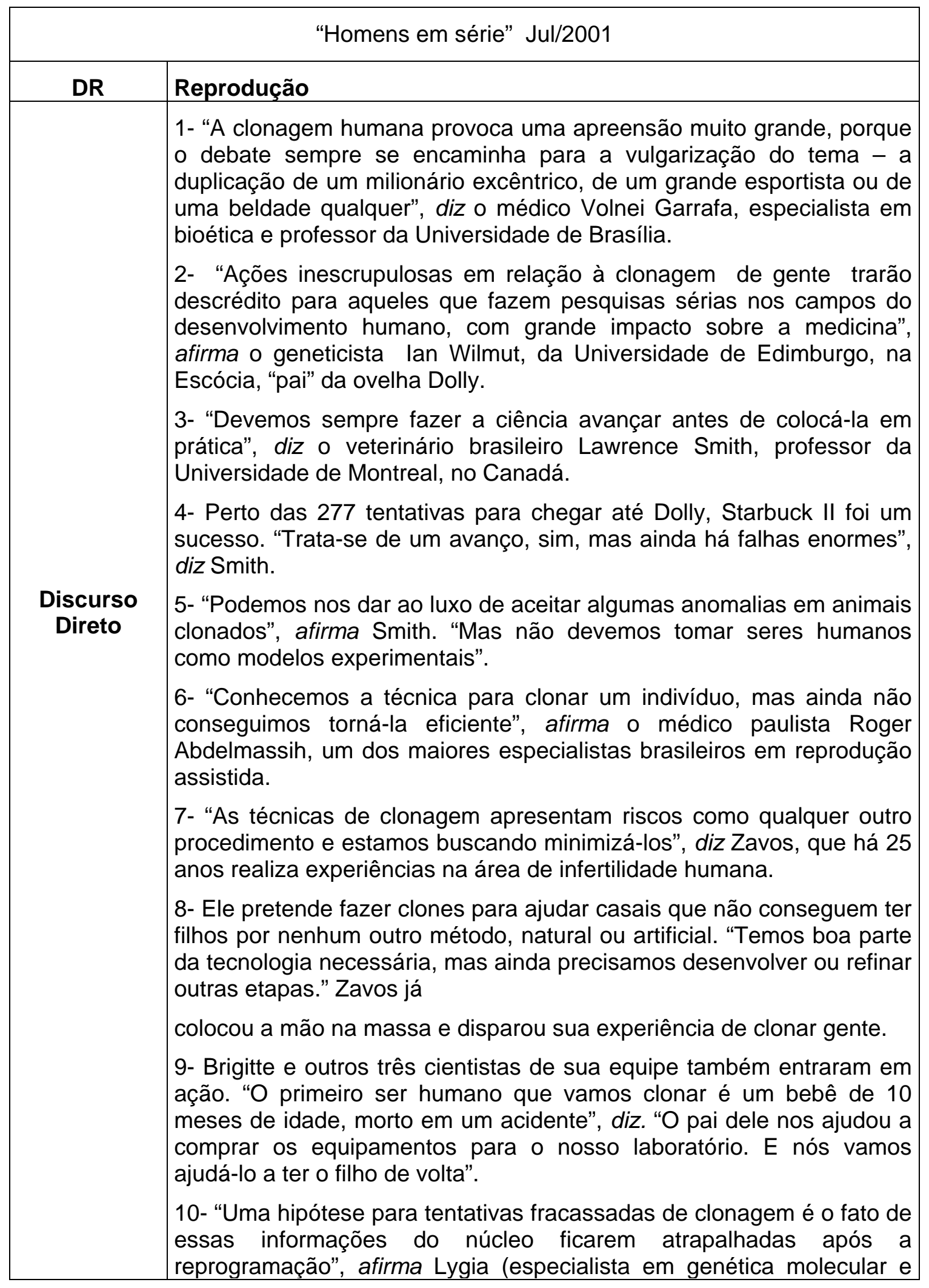




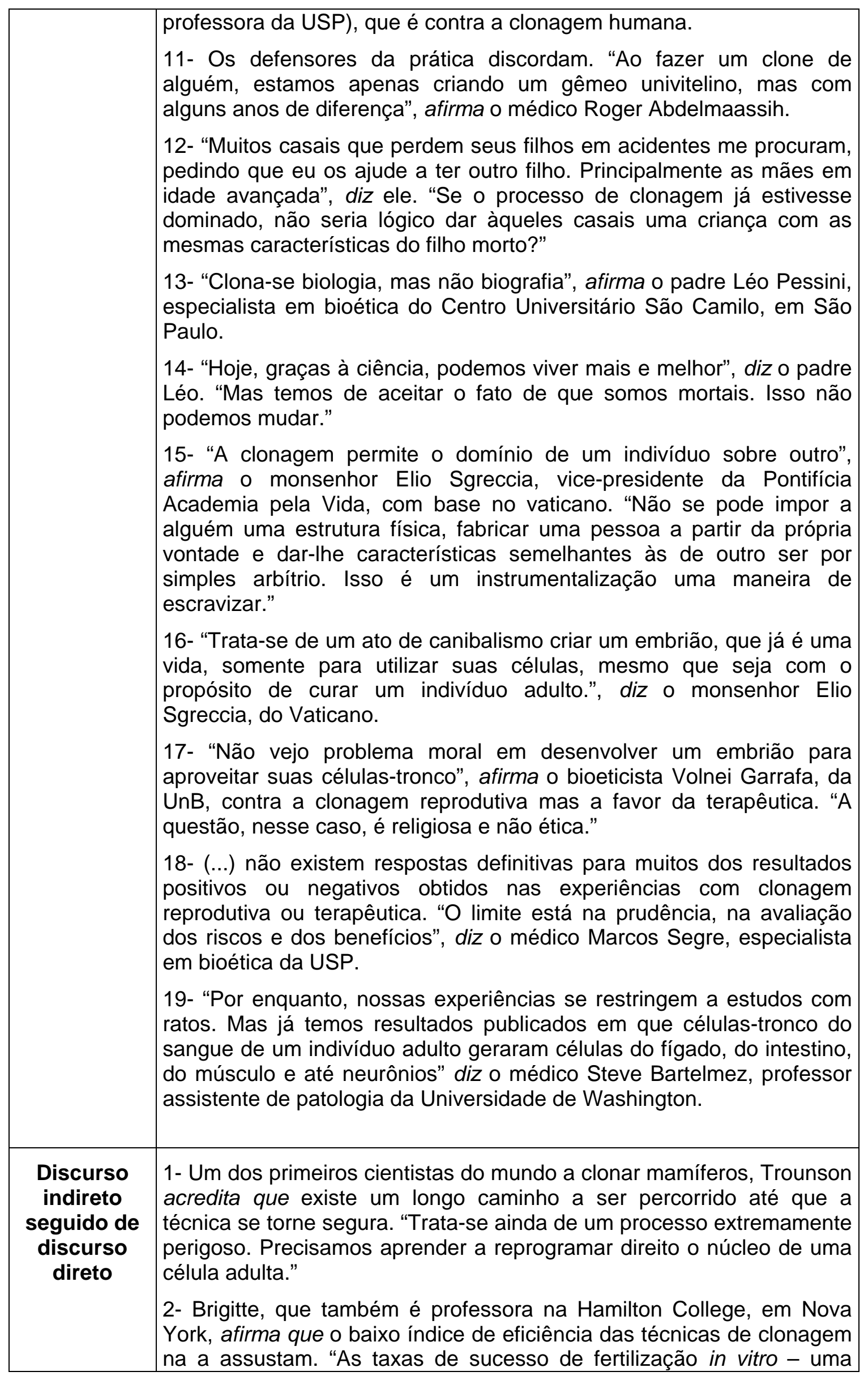




\begin{tabular}{|c|c|}
\hline & $\begin{array}{l}\text { técnica que ajuda centenas de casais com dificuldades para ter filhos - } \\
\text { não são altas, ficam em torno de } 35 \% \text { para cada tentativa", diz ela. } \\
\text { "Estão próximas dos índices alcançados com a clonagem de gado - e } \\
\text { não sabemos tanto sobre reprodução em gado quanto sabemos sobre } \\
\text { reprodução humana. Por isso, estou confiante com o bom resultado da } \\
\text { nossa pesquisa." }\end{array}$ \\
\hline $\begin{array}{l}\text { Discurso } \\
\text { Indireto }\end{array}$ & $\begin{array}{l}1 \text { - Os grupos pró-vida (...) sugerem que os pesquisadores, em vez de } \\
\text { utilizarem células-tronco embrionárias, invistam na tentativa de } \\
\text { reprogramar células adultas para que se tornem células-tronco. As } \\
\text { descobertas nessa área são recentes. }\end{array}$ \\
\hline $\begin{array}{l}\text { Modalização } \\
\text { seguida de } \\
\text { discurso } \\
\text { direto }\end{array}$ & $\begin{array}{l}\text { 1- Para o pesquisador australiano Alan Trounson, diretor do instituto de } \\
\text { reprodução assistida da Universidade Monash, em Melbourne, tais } \\
\text { justificativas não se sustentam. "Clonar humanos agora, na minha } \\
\text { opinião, equivale a prescrever uma nova droga para mulheres, } \\
\text { sabendo que essa droga pode trazer problemas e efeitos reversos para } \\
\text { a prole", diz ele. "Isso não seria apropriado nem correto". } \\
\text { 2- Para o médico americano Arthur Caplan, do Centro de Bioética da } \\
\text { Universidade da Pensilvânia, na Filadélfia, o desejo de clonar um ente } \\
\text { querido ou de criar uma duplicata de si mesmo pode esconder } \\
\text { sentimentos como egoísmo e vaidade. "Não há meios de trazer de } \\
\text { volta uma pessoa morta ou recriar um atleta. Nem com clonagem. Os } \\
\text { clones são indivíduos únicos, dotados de livre-arbítrio" diz ele. }\end{array}$ \\
\hline Modalização & $\begin{array}{l}\text { 1- Na opinião dele e de outros tantos especialistas, enquanto as } \\
\text { pesquisas com mamíferos não forem animadoras, não se deve tentar } \\
\text { em gente. } \\
2 \text { Segundo Trounson, muitos problemas que aparecem na gestação, } \\
\text { como a placenta anômala e o crescimento exagerado do feto, podem } \\
\text { estar relacionados à reprogramação de certos genes. }\end{array}$ \\
\hline $\begin{array}{l}\text { Ilhas } \\
\text { textuais }\end{array}$ & Sem Ocorrência \\
\hline
\end{tabular}

\begin{tabular}{|c|c|}
\hline \multicolumn{2}{|r|}{ "Vacinas fazem bem ou mal?" fev/2001 } \\
\hline DR & Reprodução \\
\hline & $\begin{array}{l}\text { 1- "As vacinas são a mais eficiente intervenção médica que a } \\
\text { humanidade já produziu", afirma Agnaldo Roberto Pinto, doutor em } \\
\text { microbiologia e pesquisador do Instituto Adolpho Lutz, de São Paulo. }\end{array}$ \\
\hline & $\begin{array}{l}2 \text { - "Desconhecer os seus benefícios é uma estupidez sem limites", diz } \\
\text { Cláudio Pennuti, especialista do Instituto de Medicina Tropical da } \\
\text { Universidade de São Paulo. }\end{array}$ \\
\hline & $\begin{array}{l}\text { 3- "Suspender as campanhas de imunização traria muitos prejuízos à } \\
\text { população, com o retorno das epidemias do passado" diz Cláudio. }\end{array}$ \\
\hline & $\begin{array}{l}\text { 4- "É possível utilizá-las de modo mais criterioso até que se encontre } \\
\text { um jeito melhor de prevenir doenças", afirma o médico Romeu Carrillo } \\
\text { júnior, presidente da Associação Brasileira de Reciclagem e }\end{array}$ \\
\hline
\end{tabular}




\begin{tabular}{|c|c|}
\hline $\begin{array}{c}\text { Discurso } \\
\text { Direto }\end{array}$ & $\begin{array}{l}\text { Assistência em Homeopatia. } \\
\text { 5- "Vacinar é adoecer, só que brandamente, sob controle", afirma } \\
\text { Cláudio. } \\
\text { 6- "Isso é só meia-verdade", afirma Marcos Oliveira, diretor do Instituto } \\
\text { de Tecnologia em Imunobiológicos Bio-Manguinhos, do Rio de Janeiro. } \\
\text { 7- "Há esforços para otimizar vacinas existentes, como é o caso da } \\
\text { vacina contra meningite (...), diz Marcos. } \\
\text { 8- "Desde a década de } 70 \text { a vacina contra coqueluche tem sido usada } \\
\text { em experimentos com animais para estimular a superprodução de } \\
\text { insulina pelo pâncreas", diz Coulter. } \\
\text { 9- "Gostaria de saber se um desses críticos das vacinas se recusaria a } \\
\text { tomar a vacina anti-rábica se fosse mordido por um cão raivoso", diz } \\
\text { Cláudio. }\end{array}$ \\
\hline $\begin{array}{l}\text { Discurso } \\
\text { indireto } \\
\text { seguido de } \\
\text { discurso } \\
\text { direto } \\
\end{array}$ & Sem Ocorrência \\
\hline $\begin{array}{l}\text { Discurso } \\
\text { Indireto }\end{array}$ & $\begin{array}{l}\text { 1- Agnaldo e Cláudio admitem que não existem vacinas } 100 \% \text { seguras. } \\
\text { Mas acham que usar os efeitos adversos dos preventivos para clamar } \\
\text { contra as campanhas de vacinação fere o bom senso. } \\
\text { 2- O epidemologista Robert Haley, do Centro Médico da Universidade } \\
\text { do Sudoeste do Texas, em Dallas, Estados Unidos, adverte que é } \\
\text { preciso levar em conta outros fatores, como a exposição dos militares a } \\
\text { armas químicas e a munição fabricada com urânio empobrecido. } \\
\text { 3- Primeiro, argumenta Cláudio, porque tais efeitos seriam tão raros } \\
\text { que se tornariam insignificantes diante do benefício proporcionado } \\
\text { pelas vacinas. } \\
\text { 4- Os antivacinistas afirmam que as vacinas começaram a ser usadas } \\
\text { quando as principais doenças infecciosas já estavam em declínio, } \\
\text { vencidas pelas defesas naturais do organismo. }\end{array}$ \\
\hline $\begin{array}{l}\text { Modalização } \\
\text { seguida de } \\
\text { discurso } \\
\text { direto }\end{array}$ & $\begin{array}{l}\text { 1- Segundo os antivacinistas, a ineficiência é comprovada pelas } \\
\text { estatísticas epidemiológicas. "É certo que a varíola desapareceu do } \\
\text { mundo e a pólio foi virtualmente eliminada do ocidente pela vacinação. } \\
\text { Mas é exagero supor que as vacinas são responsáveis pelo controle de } \\
\text { todas as epidemias do passado", diz Harold Buttram, membro da } \\
\text { Academia Americana de Medicina Ambiental. }\end{array}$ \\
\hline Modalização & $\begin{array}{l}\text { 1- Segundo o virologista Hiromu Yoshida, chefe da equipe de } \\
\text { pesquisadores que investiga o caso, o achado não representa uma } \\
\text { ameaça à saúde publica dos japoneses. } \\
\text { 2- Segundo Neal, vacinas como as da hepatite B, poliomielite, sarampo } \\
\text { e mesmo a veterana varíola são aplicadas em escala mundial sem que } \\
\text { os cientistas conheçam até hoje seus mecanismos de ação. } \\
\text { 3- Para os vacinistas, o problema foi causado pela carga de } 17 \text { vacinas } \\
\text { que os militares tomaram antes de seguir para a guerra. } \\
\text { 4- Segundo Hooper, o HIV surgiu da mutação do vírus da pólio usada } \\
\text { em vacinações no Congo, entre } 1957 \text { e } 1960 \text {. }\end{array}$ \\
\hline
\end{tabular}




\begin{tabular}{|c|l|}
\hline & $\begin{array}{l}\text { 5- O químico porém, segundo Capra, não teve tempo para empreender } \\
\text { novas pesquisas e seus seguidores persistiram na trilha original. }\end{array}$ \\
\hline $\begin{array}{c}\text { Ilhas } \\
\text { textuais }\end{array}$ & Sem ocorrência \\
\hline
\end{tabular}

Na reportagem "Homens em série" observamos um grande número de citações em discurso direto que simula as falas dos especialistas como se realmente tivessem sido proferidas desse modo. Temos claramente duas situações de enunciação, a do discurso relatante e a do discurso relatado, o enunciador (jornalista) se abstém de expressar opinião sobre os prós e contra da clonagem humana.

No que se refere aos interlocutores, os verbos de elocução ou dicendi indicam que houve um ato de fala, das 19 citações em DD 17 apresentam ora o verbo "dizer" ora o "afirmar", nas outras duas citações (4 e 8) não há a presença do verbo, sendo o DD é marcado apenas pelas aspas.

Temos um DI e as formas em DI aparecem sempre seguidas de DD, o conteúdo do pensamento do outro é relatado em DI e imediatamente há a asserção em DD, ou seja, o DD comprova a veracidade da informação dada em DI, uma vez que o DD simula restituir a própria fala do cientista. Já as modalizações, ora aparecem sozinhas ora articuladas ao DD. Na reportagem, temos um total de 26 ocorrências de DR.

Na reportagem seguinte "Vacinas fazem bem ou mal?", o número de DR é menor que na reportagem anterior, são 19 ocorrências no total (contra 26 da outra), das quais 9 são em DD, 4 em DI, 5 modalizações e 1 modalização seguida de DD. Essa diferença no número de DR pode ser atribuída ao tema "Clonagem Humana" que é polêmico, delicado, pois mexe com as crenças da humanidade. As opiniões são muito divididas e o enunciador se vê obrigado a mostrar as várias posições perante o assunto. Daí o grande número de DR e principalmente de $D D$, já que o enunciador parece querer se manter neutro na discussão, não assumindo para si qualquer posição.

$\mathrm{Na}$ reportagem sobre vacinas o enunciador dá as informações e cita alguns especialistas. Como o tema é menos polêmico, o jornalista parece não ter receio de dar, ele mesmo, as informações, daí o número menor de DR.

De modo geral, as reportagens da Superinteressante são estruturadas pelo discurso relatado. $\mathrm{O}$ enunciador ao longo do texto relata as assertivas de 
terceiros, ele por si só não se responsabiliza pelo que está sendo discutido, pois não possui conhecimento científico necessário.

- Galileu

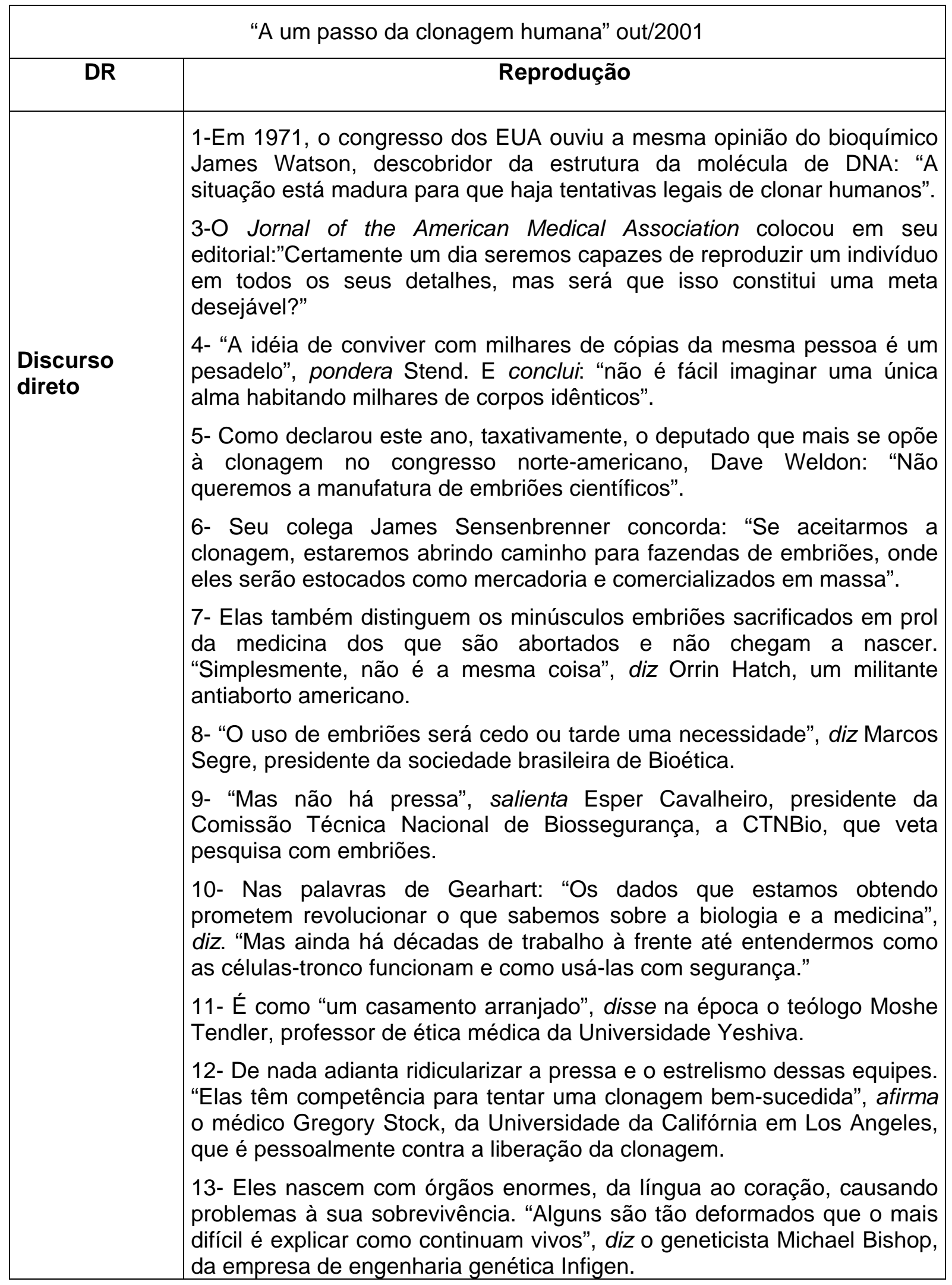




\begin{tabular}{|c|c|}
\hline & $\begin{array}{l}\text { 14- Ninguém sabe exatamente como surgem esses problemas, muito } \\
\text { menos como resolvê-los. Vale, nesse caso, a advertência de Wilmut: } \\
\text { "Como alguém se atreveria a correr o risco de clonar um bebê, quando o } \\
\text { resultado é rigorosamente imprevisível?" }\end{array}$ \\
\hline $\begin{array}{l}\text { Discurso } \\
\text { indireto } \\
\text { seguido de } \\
\text { discurso } \\
\text { direto }\end{array}$ & $\begin{array}{l}\text { 1- Bush recebeu uma carta, assinada por mais de } 80 \text { ganhadores do } \\
\text { Nobel, alertando que a pesquisa médica nos EUA seria prejudicada se } \\
\text { não pudesse usar embriões. "A decisão do presidente é um bom ponto de } \\
\text { partida, mas tem limitações", disse Johns Hopkins, que identificou } \\
\text { células-tronco em fetos humanos, } 1998 \text {. }\end{array}$ \\
\hline \multirow{10}{*}{$\begin{array}{l}\text { Discurso } \\
\text { indireto }\end{array}$} & $\begin{array}{l}\text { 1- O próprio Wilmut foi muito cauteloso ao anunciar, em 1997, que havia } \\
\text { criado o primeiro clone de um animal adulto - a ovelha Dolly. } \\
\text { 2- A maioria dos cientistas considerou que as evidências disponíveis } \\
\text { eram insuficientes para decidir (...) } \\
\text { 3- Um argumento fundamental para essas correntes é que a reprodução } \\
\text { só é aceitável moralmente se for feita pela união natural de um óvulo e } \\
\text { um espermatozóide. }\end{array}$ \\
\hline & $\begin{array}{l}\text { 4- Muitos consideram que, como o filho é uma mistura de genes dos pais, } \\
\text { não seria ético reproduzir apenas um deles por meios artificiais. }\end{array}$ \\
\hline & $\begin{array}{l}\text { 5- Os especialistas explicaram que isso não basta para estudar } \\
\text { adequadamente o complicado processo da transformação das células- } \\
\text { tronco em órgãos. }\end{array}$ \\
\hline & $\begin{array}{l}\text { 6- Prova disso foi o resultado divulgado este ano pela médica australiana } \\
\text { Orly Lacham-Kaplan, da Universidade de Melbourne, que anunciou ter } \\
\text { gerado um embrião de rato sem espematozóide, utilizando uma técnica } \\
\text { semelhante à que lan Wilmut empregou para gerar Dolly. }\end{array}$ \\
\hline & $\begin{array}{l}\text { 7- Algo parecido aconteceu nos Estados Unidos, onde o embriologista } \\
\text { Gianpiero Palermo, da Universidade Cornell, anunciou este ano que a } \\
\text { clonagem pode gerar óvulos artificiais. }\end{array}$ \\
\hline & $\begin{array}{l}8 \text { - Dois anos depois, o físico desempregado norte-americano Richard } \\
\text { Seed anunciou que, se essa técnica viesse a ser proibida nos EUA, } \\
\text { burlaria a lei e atenderia casais inférteis que o procurassem. }\end{array}$ \\
\hline & $\begin{array}{l}\text { 9- O problema, dizem Stock e a imensa maioria dos cientistas, é que } \\
\text { tentar não significa conseguir; e, o que é pior, se a experiência fracassar, } \\
\text { pode ter conseqüências sérias para o bebê e a mãe }\end{array}$ \\
\hline & $\begin{array}{l}\text { 10- Este ano Zavos declarou ao Congresso americano que cuidados } \\
\text { serão tomados e, caso se perceba algo errado, a experiência será } \\
\text { imediatamente interropida. }\end{array}$ \\
\hline & $\begin{array}{l}\text { 11- A lista das dificuldades na clonagem animal, no entanto, é tão } \\
\text { impressionante que a maioria dos cientistas (...) acredita que não é hora } \\
\text { ainda de atender os casais inférteis. }\end{array}$ \\
\hline & $\begin{array}{l}\text { 12- Eles alegam que, mesmo entre os pouquíssimos animais que se } \\
\text { conseguiu clonar até hoje, observam-se todos os tipos de defeitos. }\end{array}$ \\
\hline $\begin{array}{l}\text { Discurso } \\
\text { indireto quase } \\
\text { textual }\end{array}$ & $\begin{array}{l}\text { 1- Davor Solter declarou, com todas as letras, que "a clonagem de um } \\
\text { mamífero é biologicamente impossível" }\end{array}$ \\
\hline Modalização & $\begin{array}{l}\text { 1- afirmação parecida se ouviria, três anos mais tarde, do geneticista } \\
\text { americano Joshua Lederberg, um dos criadores da engenharia genética, } \\
\text { segundo o qual " a primeira clonagem de seres humanos não vai demorar }\end{array}$ \\
\hline
\end{tabular}




\begin{tabular}{|c|l|}
\hline $\begin{array}{c}\text { Seguida de } \\
\text { discurso } \\
\text { direto }\end{array}$ & $\begin{array}{l}\text { muito" } \\
\text { 2- A saída, segundo Gaylin, foi discutir um tema científico que realmente } \\
\text { abalasse as conviç̧ões das pessoas: a clonagem. "Ela desperta nossos } \\
\text { medos mais profundos", disse à época. "Foi o que atraiu a atenção do } \\
\text { publico para o instituto" confirma Callahan. }\end{array}$ \\
\hline Modalização & $\begin{array}{l}\text { 1- Para os conservadores, porém, não há meio termo. Tomando como } \\
\text { princípio que a clonagem é um desrespeito à vida, não esperam que } \\
\text { algum bom possa sair dela. } \\
\text { 2- (...) avançaram devagar, sob críticas e dúvidas de colegas, para os } \\
\text { quais a implantação de um embrião em um útero de aluguel seria } \\
\text { difićlimo, mais uma arte do que uma ciência. }\end{array}$ \\
\hline Ilhas textuais \\
$\begin{array}{l}\text { 1- Houve quem denunciasse o que parecia um "desrespeito" com o óvulo } \\
\text { e com o espermatozóide, ao serem "forçados contra a vontade" a se } \\
\text { unirem num tubo de ensaio. }\end{array}$ \\
\hline
\end{tabular}

\begin{tabular}{|c|l|}
\hline \multicolumn{1}{|c|}{ "AIDS: imunes por natureza" set/2003 } \\
\hline DR & \multicolumn{1}{|c|}{ Reprodução } \\
\hline $\begin{array}{c}\text { Discurso } \\
\text { direto }\end{array}$ & $\begin{array}{l}\text { 1- "Os testes de fase 2 devem acabar em dois anos, e esperamos } \\
\text { começar os testes de fase } 3 \text { [etapa final] logo em seguida", disse a } \\
\text { Galileu Sarah Rowland-Jones, uma das líderes do grupo de Oxford. } \\
\text { 2- Na maioria dos casos é difícil determinar o que está por trás dos } \\
\text { fenômenos, explica o cientista Esper Kallas, da Unifesp (Universidade } \\
\text { Federal de São Paulo). } \\
\text { 3- "Estamos tentando identificar alguma coisa diferente que ajude no } \\
\text { desenvolvimento de vacinas, mas por enquanto não achamos nada em } \\
\text { comum entre essas pessoas", conta Kallas. "Mas o estudo está em } \\
\text { andamento". } \\
\text { 4- "Não sabemos ainda o que faz a reação das CLT, aparentemente } \\
\text { eficaz nas mulheres resistentes ao HIV já que outras chegam a a } \\
\text { apresentar reações mais fortes, mas acabam sucumbindo", diz a cientista } \\
\text { inglesa. } \\
\text { 5- "O vírus engana o sistema imune ao criar novas mutações em suas } \\
\text { proteínas e ganhar uma aparência diferente para os anticorpos", explica o } \\
\text { cientista Kenneth Roux, da Universidade Estadual da Flórida. } \\
\text { 6- "O 2G12 não oferece proteção contra todos os tipos de HIV, mas age } \\
\text { num espectro bastante amplo e ataca a maioria deles", diz Roux. } \\
\text { 7- "Se soubermos criar um antígeno com o arranjo de açucares correto, } \\
\text { pode surgir uma vacina que induz o corpo a produzir seus próprios } \\
\text { anticorpos tipo 2G12", diz Roux. } \\
\text { 8- "É provável que a varíola tenha tido um papel importante", arrisca } \\
\text { Buhler. } \\
\text { 9- "A estratégia de vacina que deve ganhar é a que combina diferentes } \\
\text { produtos", diz Roux. }\end{array}$ \\
\hline
\end{tabular}




\begin{tabular}{|c|c|}
\hline $\begin{array}{l}\text { Discurso } \\
\text { indireto } \\
\text { seguido de } \\
\text { discurso } \\
\text { direto } \\
\end{array}$ & Sem Ocorrência \\
\hline $\begin{array}{c}\text { Discurso } \\
\text { indireto }\end{array}$ & Sem Ocorrência \\
\hline $\begin{array}{c}\text { Discurso } \\
\text { indireto quase } \\
\text { textual }\end{array}$ & Sem Ocorrência \\
\hline $\begin{array}{c}\text { Modalização } \\
\text { Seguida de } \\
\text { discurso } \\
\text { direto }\end{array}$ & Sem Ocorrência \\
\hline Modalização & Sem Ocorrência \\
\hline Ilhas textuais & $\begin{array}{l}\text { 1- Chamados na literatura médica de "expostos não-infectados", esses } \\
\text { indivíduos possuem no corpo mecanismos capazes de barrar a infecção } \\
\text { por HIV sem qualquer ajuda de medicamentos. }\end{array}$ \\
\hline
\end{tabular}

$\mathrm{Na}$ reportagem "A um passo da clonagem humana", observamos um total de 33 citações. O número de citações em DD e DI é praticamente o mesmo, 14 ocorrências para a primeira e 12 para a segunda. Os verbos introdutores de DD são de dois tipos: se os verbos "dizer", "confirmar" e "declarar" são aparentemente neutros, o mesmo não se pode dizer dos "salientar" e "ponderar", que são carregados de sentidos. O "salientar" implica que a fala relatada ressalta determinado ponto considerado importante, e "ponderar" denota uma reflexão sobre o assunto, sendo essa reflexão atribuída ao especialista.

A estrutura do texto em DI denuncia um enunciador que traduz as falas citadas, já que não são as palavras exatas que são relatadas, mas sim 0 conteúdo do pensamento. Na maior parte da reportagem, encontramos DD e DI se alternando.

As modalizações, quando aparecem sozinhas, se remetem a discursos de instituições, entidades, ou grupos: "Para os conservadores...", “... de colegas, para o quais...". A modalização se refere ao discurso de um especialista em apenas um caso, quando é seguida de DD. Encontramos uma ocorrência que enquadramos como ilha textual, as palavras aspeadas estão integradas à sintaxe do discurso relatante, o enunciador ao mesmo tempo usa e menciona as palavras. Ao colocar as palavras entre aspas, o enunciador 
chama a atenção do co-enunciador para o fato de que o dizer não é dele e sim do outro e que ele aparentemente não concorda com os termos contidos na fala citada.

A reportagem seguinte se intitula "AIDS: imunes por natureza". Nela foram observadas apenas 10 citações, 9 em DD e uma ilha textual. A reportagem é bastante informativa, nada de discussões polêmicas. $O$ enunciador informa o andamento de uma pesquisa sobre vacina contra a AIDS. As vozes dos especialistas dão apenas informações sobre o andamento das pesquisas.

\section{- Pesquisa FAPESP}

"Lei Polêmica: projeto restringe poder da CTNBio, proíbe clonagem terapêutica e mobiliza cientistas" mar/2004

\begin{tabular}{|c|l|}
\hline DR & \multicolumn{1}{|c|}{ Reprodução } \\
\hline Discurso & $\begin{array}{l}\text { 1- "É fundamental para o desenvolvimento nacional que as pesquisas } \\
\text { oriundas das instituições públicas possam ser rapidamente } \\
\text { incorporadas ao nosso setor produtivo, sob pena de a sociedade } \\
\text { brasileira não poder usufruir dos investimentos em ciência e } \\
\text { tecnologia no Brasil", dizem os representantes de 13 entidades } \\
\text { científicas, entre elas a Academia Brasileira de Ciências, em carta } \\
\text { encaminhada aos senadores no dia 18 de fevereiro. } \\
\text { 2- O conselho Superior da FAPESP também se manifestou. Em } \\
\text { documento entregue ao presidente do senado José Sarney, pelo } \\
\text { diretor-científico, José Fernando Perez, a Fundação "apela aos } \\
\text { parlamentares para que ouçam os representantes acreditados da } \\
\text { comunidade científica no sentido de transformar o texto de lei em } \\
\text { instrumento de progresso e independência tecnológica, evitando } \\
\text { assim danos irreparáveis aos mecanismos de geração de } \\
\text { conhecimento de riqueza". } \\
\text { 3- A comunidade científica reagiu também negativamente à proibição } \\
\text { das pesquisas com células-tronco para fins terapêuticos. "Os textos } \\
\text { do projeto de lei que tratam da pesquisa com células-tronco } \\
\text { embrionárias são particularmente alarmantes quanto aos efeitos na } \\
\text { saúde pública", afirma o documento elaborado pelas 13 entidades. "A } \\
\text { terapia celular com células tronco embrionárias pode representar a } \\
\text { esperança no tratamento de mais de } 5 \text { milhões de pessoas, a maioria } \\
\text { crianças e jovens. Não se trata de produzir embriões para esta } \\
\text { finalidade, mas utilizar aqueles que são descartados em clínicas de } \\
\text { fertilização." } \\
\text { 4- O deputado Renildo Calheiros (PcdoB/PE)(...) sob pressão de } \\
\text { ambientalistas e da bancada evangélica, modificou o projeto. "O } \\
\text { resultado foi um Frankenstein jurídico", avalia Carlos Vogt, presidente } \\
\text { da FAPESP. } \\
\text { 5- A Ministra do Meio Ambiente, Marina Silva, comemorou os }\end{array}$ \\
\hline
\end{tabular}




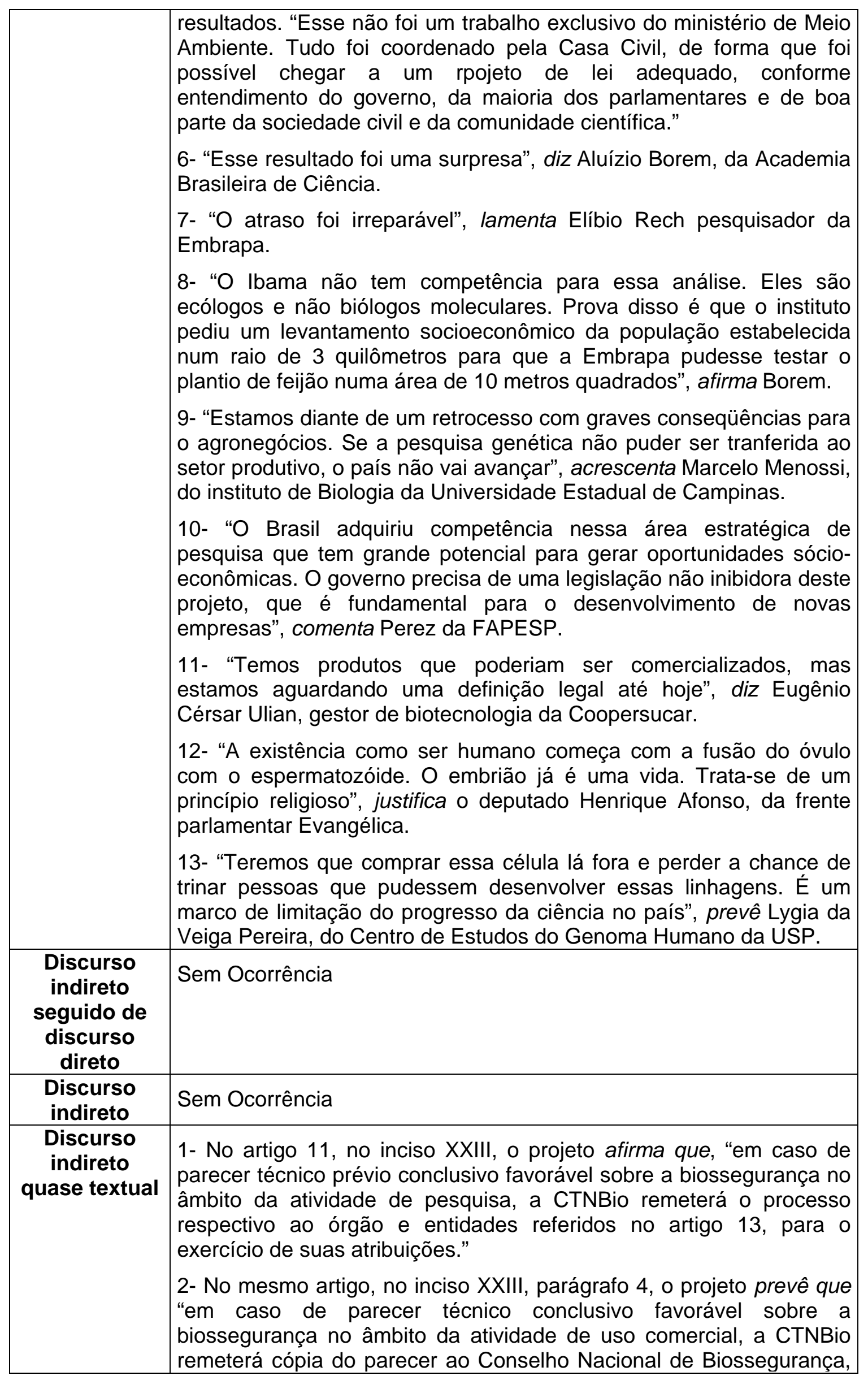




\begin{tabular}{|c|c|}
\hline & $\begin{array}{l}\text { para o exercício de suas atribuições" } \\
\text { 3- E, no artigo 13, parágrafo1, o projeto diz que, "após manifestação } \\
\text { favorável do Conselho Nacional de Biossegurança, caberá em } \\
\text { decorrência de análise específica e decisão pertinente, ao órgão } \\
\text { competente do Ministério do Meio Ambiente, no caso o lbama, } \\
\text { licenciar e emitir autorização e registros, fiscalizar e monitorar } \\
\text { produtos e atividades em envolvam OGMs e seus derivado a serem } \\
\text { liberados no ecossistema". }\end{array}$ \\
\hline $\begin{array}{c}\text { Modalização } \\
\text { seguida de } \\
\text { discurso } \\
\text { direto }\end{array}$ & $\begin{array}{l}\text { 1- Para o Ministério de Meio Ambiente (MMA), não há nenhuma } \\
\text { dúvida em relação ao projeto. "O texto aprovado dá ao lbama poderes } \\
\text { para questionar no Conselho Nacional de Biossegurança pareceres } \\
\text { da CTNBio para a comercialização dos transgênicos(...)", informa a } \\
\text { acessória do MMA pelo site www.mma.gov.br } \\
\text { 2- Para Marco Antonio Zago, da Faculdade de Medicina de Ribeirão } \\
\text { Preto, da USP (...) a preocupação da Câmara está equivocada. "O } \\
\text { debate deveria ser o que se faz com embriões humanos congelados } \\
\text { em clínicas", sugere. } \\
\text { 3- Na avaliação de Mayana Zatz, coordenadora do Centro de Estudo } \\
\text { do Genoma Humano, houve uma confusão entre os conceitos de } \\
\text { clonagem reprodutiva, clonagem terapêutica e terapia celular com } \\
\text { células-tronco. "A clonagem reprodutiva que seria a tentativa de } \\
\text { produzir uma cópia de um individuo deve mesmo ser condenada e } \\
\text { proibida", ela ressalva. } \\
\text { 4- De acordo com Reginaldo Minaré, advogado especialista em } \\
\text { biotecnologia. "O lbama ou a Anvisa poderão, cada um no seu campo } \\
\text { de atuação, exigir mais estudos sobre a biossegurança da atividade } \\
\text { ou produto oriundo da engenharia genética, pois, de acordo com o } \\
\text { texto, essas exigências serão feitas após a manifestação favorável do } \\
\text { conselho ministerial", ele prevê. }\end{array}$ \\
\hline Modalização & Sem Ocorrência \\
\hline Ilhas textuais & $\begin{array}{l}\text { 1- Calheiros modificou o texto para "valorizar o papel técnico" da } \\
\text { comissão, como ele justificou em seu relatório. } \\
\text { 2- A julgar pela reação da comunidade científica, a "maioria" não } \\
\text { inclui boa parte dos pesquisadores. } \\
\text { 3- Os representantes da comunidade científica propõem ao Senado } \\
\text { que alterem o texto, credenciando a CTNBio como a "única e } \\
\text { definitiva instância" para julgar a natureza científica da matéria e que } \\
\text { seus pareceres pautem não apenas as atividades de pesquisa, mas } \\
\text { também a comercialização. } \\
\text { 4- O Ministério do Meio Ambiente, eles argumentam, poderá se } \\
\text { manifestar sobre o assunto, no âmbito da própria comissão que será } \\
\text { formada por } 27 \text { doutores dos quais "especialistas de notório saber } \\
\text { científico e técnico" e } 15 \text { representantes dos ministérios e entidades } \\
\text { civis. } \\
5-\text { O resultado desta "confusão" poderá trazer sérios prejuízos para a }\end{array}$ \\
\hline
\end{tabular}




\begin{tabular}{|l|l|}
\hline & $\begin{array}{l}\text { pesquisa e colocar o Brasil na dependência de importar tecnologia de } \\
\text { países que autorizam essa investigação. }\end{array}$ \\
\hline
\end{tabular}

\begin{tabular}{|c|c|}
\hline \multicolumn{2}{|r|}{ "O alvo é a saúde humana" nov/2002 } \\
\hline DR & Reprodução \\
\hline \multirow[t]{7}{*}{$\begin{array}{l}\text { Discurso } \\
\text { direto }\end{array}$} & $\begin{array}{l}\text { 1-“Os resultados, se positivos, devem servir para guiar outros estudos } \\
\text { clínicos (em humanos) da vacina gênica", comenta Silva. }\end{array}$ \\
\hline & $\begin{array}{l}\text { 2- "Bastam } 50 \text { miligramas da vacina para começarmos os testes", diz } \\
\text { Abdallah. }\end{array}$ \\
\hline & $\begin{array}{l}\text { 3- "Não é fácil", diz o pesquisador da USP. "Temos agora de dominar } \\
\text { os processos tecnológicos". }\end{array}$ \\
\hline & $\begin{array}{l}\text { 4- "Os primeiros testes indicam que a vacina pode deter a ação de } \\
\text { qualquer Mycobacterium", conta Silva. }\end{array}$ \\
\hline & $\begin{array}{l}\text { 5- "Aparentemente", diz Karla, "Podemos desenvolver outras } \\
\text { estratégias para as microesferas se degradarem em tempos } \\
\text { diferentes, combinando uma ação mais rápida e outra mais lenta." }\end{array}$ \\
\hline & $\begin{array}{l}\text { 6- "Mesmo usada como medicamento, essa vacina não apresenta os } \\
\text { mesmos riscos que as outras terapias gênicas", afirma o pesquisador } \\
\text { da USP. "já provamos que o gene não se incorpora no genoma das } \\
\text { pessoas tratadas." }\end{array}$ \\
\hline & $\begin{array}{l}\text { 7- Alexandrina detectou a linha de pesquisa que se abriu: "Se essa } \\
\text { vacina também funcionar em outras doenças auto-imunes, poderá ser } \\
\text { usada em terapia, mas do que em iminização." }\end{array}$ \\
\hline $\begin{array}{l}\text { Discurso } \\
\text { indireto } \\
\text { seguido de } \\
\text { discurso } \\
\text { direto }\end{array}$ & Sem Ocorrência \\
\hline $\begin{array}{l}\text { Discurso } \\
\text { indireto }\end{array}$ & Sem Ocorrência \\
\hline $\begin{array}{l}\text { Discurso } \\
\text { indireto } \\
\text { quase textual }\end{array}$ & Sem Ocorrência \\
\hline $\begin{array}{l}\text { Modalização } \\
\text { seguida de } \\
\text { discurso } \\
\text { direto }\end{array}$ & Sem Ocorrência \\
\hline Modalização & $\begin{array}{l}\text { 1-"Segundo Hald Ali Abdallah, pesquisador da Faculdade de Medicina } \\
\text { da USP em São Paulo (...), não há relatos de que tenham surgido } \\
\text { reações graves além de febre moderada e inchaço no local da } \\
\text { aplicação, típicas de qualquer vacina." }\end{array}$ \\
\hline & $\begin{array}{l}\text { 2- Segundo Rodrigues, há resultados promissores também contra } \\
\text { leishmaniose. }\end{array}$ \\
\hline Ilhas textuais & Sem Ocorrência \\
\hline
\end{tabular}


Na primeira reportagem, verificamos a presença de 25 citações, o que parece confirmar a hipótese de que temas mais polêmicos exigem maior número de DR. Os introdutores de DD se alternam ao longo de todo o texto, ora temos verbos de elocução ou dicendi ora apenas aspas, com ausência dos verbos. Essa reportagem apresenta um caso diferente de discurso indireto, é o DI quase textual, uma vez que há a oração subordinada substantiva objetiva direta, ou seja, integração sintática do discurso relatado ao discurso relatante. As modalizações aparecem apenas seguidas de DD. Encontramos 5 ocorrências de llhas textuais, mais uma vez o recurso das aspas é usado para marcar palavras e expressões que, embora estejam integradas à sintaxe discursiva, são de outro lugar e não representam a opinião do enunciador.

Na segunda reportagem, temos 9 citações, 7 em DD e 2 modalizações. Assim como ocorreu na Galileu, a reportagem sobre vacina informa o andamento das pesquisas com vacina gênica. O DR está presente, já que se trata de uma reportagem, mas em numero reduzido, os especialistas não entram em debate, apenas comunicam o andamento e a quantas andam as pesquisas, não sendo necessário colocar no texto um grande número de citações.

A seguir, analisaremos as revistas Scientific American Brasil e Ciência Hoje em conjunto, pois encontramos apenas uma reportagem em cada sobre "Vacinas".

- Scientific American Brasil

\begin{tabular}{|c|l|}
\hline \multicolumn{2}{|c|}{ "AIDS: a grande batalha da vacina" set/2002 } \\
\hline DR & \multicolumn{1}{|c|}{ Reprodução } \\
\hline direto & $\begin{array}{l}\text { 1- "Estamos em uma época interessante para a pesquisa da aids", } \\
\text { observa Gregg Gonsalves, diretor da associação de tratamento e } \\
\text { prenvenção Gay Men's Health Crisis, de Nova York. "Acho que } \\
\text { entramos agora no segundo ato." } \\
\text { 2- "Estamos tentando provocar uma resposta imunológica que não } \\
\text { existe na natureza", admite Max Essex, da Escola de Saúde Pública } \\
\text { de Harvard. } \\
\text { 3- " A idéia", diz ele, "não é que a vacina de DNA seja uma boa } \\
\text { solução por si só, e sim, que funcione como um estimulante do } \\
\text { sistema imunológico, que, meses depois, deverá receber a vacina de } \\
\text { adenovírus." } \\
\text { 4- "O que distingue o HIV de todos os outros vírus humanos é sua } \\
\text { capacidade de sofrer mutações muito rapidamente", diz Essex. }\end{array}$ \\
\hline
\end{tabular}




\begin{tabular}{|c|c|}
\hline & $\begin{array}{l}\text { 5- A reatividade múltipla poderia acontecer em circunstâncias ideais, } \\
\text { mas, diz ele, "se não conseguirmos disso, devemos usar vacinas } \\
\text { específicas para os subtipos". }\end{array}$ \\
\hline $\begin{array}{l}\text { Discurso } \\
\text { indireto } \\
\text { seguido de } \\
\text { discurso } \\
\text { direto }\end{array}$ & $\begin{array}{l}\text { 1- Lawrence Corey, da Rede de Experimentos de Vacinas contra o } \\
\text { HIV, financiada pelo governo americano diz que, vacinas como a da } \\
\text { Merck, (...), provavelmente não vão prevenir a infecção, mas são uma } \\
\text { arma no combate ao vírus quando a infecção já está instalada. "Em } \\
\text { vez de avançar e se transformar em aids em oito anos, o processo vai } \\
\text { consumir } 25 \text { anos", prevê. }\end{array}$ \\
\hline \multirow[t]{5}{*}{$\begin{array}{l}\text { Discurso } \\
\text { indireto }\end{array}$} & $\begin{array}{l}\text { 1- Alguns cientistas acham que as vacinas que induzem as reações } \\
\text { desencadeadas pelo sistema imunológico quando o vírus se instala } \\
\text { na célula já têm o seu valor. } \\
\text { 2- A Vax Gen afirma que vai pedir permissão à Food and Drug } \\
\text { Administation, (...), para vender as vacina mesmo que os } \\
\text { experimentos de terceira fase mostrem que ela reduz a probabilidade } \\
\text { de infecção em apenas } 30 \% \text {. }\end{array}$ \\
\hline & $\begin{array}{l}\text { 3- Donald } P \text {. Francis, presidente e co-fundador da empresa, observa } \\
\text { que a eficácia da primeira vacina contra poliomielite, (...), era de } \\
\text { apenas } 60 \% \text { e, mesmo assim, fez com que a incidência de pólio } \\
\text { caísse rápida e dramaticamente no Estados Unidos. }\end{array}$ \\
\hline & $\begin{array}{l}\text { 4- Emini e colaboradores disseram que } 42 \% \text { dos voluntários que } \\
\text { receberam a dose maior da vacina de DNA puro aumentaram o } \\
\text { número de células } T \text { citotóxicas capazes de atacar as células } \\
\text { infectadas pelo HIV. }\end{array}$ \\
\hline & $\begin{array}{l}\text { 5- Emini diz que ele e seus colaboradores estão enfatizando a } \\
\text { imunidade celular em parte por causa dos resultaaados } \\
\text { decepcionantes obtidos até agora com vacinas destinadas a gerar } \\
\text { respostas puramente humorais. }\end{array}$ \\
\hline & $\begin{array}{l}\text { 6- Essex (...) afirma que, se os pesquisadores não tiverem certeza de } \\
\text { que uma vacina contra uma variedade possa também combater outra, } \\
\text { devem se limitar a testar vacinas para a variedade predominante nas } \\
\text { populações estudadas. }\end{array}$ \\
\hline $\begin{array}{l}\text { Discurso } \\
\text { indireto } \\
\text { quase textual }\end{array}$ & Sem Ocorrência \\
\hline $\begin{array}{l}\text { Modalização } \\
\text { seguida de } \\
\text { discurso } \\
\text { direto }\end{array}$ & Sem Ocorrência \\
\hline Modalização & $\begin{array}{l}\text { 1- Segundo ele, há potencial para uma resposta substancial a vários } \\
\text { subtipos, em termos de imunidade celular, mas não se pode dizer o } \\
\text { mesmo em relação aos anticorpos. }\end{array}$ \\
\hline Ilhas textuais & $\begin{array}{l}\text { 1- A primeira vacina em potencial a chegar à terceira fase consiste de } \\
\text { gp } 120 \text {, uma proteína que cobre o invólucro externo do HIV de } \\
\text { saliências e que o vírus usa como "ganchos" para se prender e } \\
\text { infectar as células. }\end{array}$ \\
\hline
\end{tabular}




\begin{tabular}{|c|c|}
\hline \multicolumn{2}{|r|}{ "Vacina genética contra tuberculose" out/1999 } \\
\hline DR & Reprodução \\
\hline $\begin{array}{l}\text { Discurso } \\
\text { direto }\end{array}$ & $\begin{array}{l}\text { 1- "Mas quando se analisa a incidência da tuberculose em relação ao } \\
\text { tamanho da população, as situações mais críticas se encontram no } \\
\text { Amazonas e no Rio de Janeiro", informa a médica Vera Maria Neder } \\
\text { Galesi, coordenadora do Programa de Controle da Tuberculose da } \\
\text { Secretaria da Saúde do Estado de São Paulo. } \\
\text { 2- "Não adianta apenas tratar o doente; é preciso cura-lo com rigor", } \\
\text { afirma Galesi. } \\
\text { 3- "Ela exige um sistema de saúde bem organizado, o que } \\
\text { infelizmente não se encontra em todos os municípios", avalia galesi. } \\
\text { 4- "Apenas estimulando os linfócitos T CD8, (...), chegaríamos a outra } \\
\text { vacina. Para fazer isso, no entanto, seria necessário produzir os } \\
\text { antígenos dentro das células, como acontece com as infecções } \\
\text { virais", relata o pesquisador. }\end{array}$ \\
\hline $\begin{array}{l}\text { Discurso } \\
\text { indireto } \\
\text { seguido de } \\
\text { discurso } \\
\text { direto } \\
\end{array}$ & Sem Ocorrência \\
\hline $\begin{array}{l}\text { Discurso } \\
\text { indireto }\end{array}$ & Sem Ocorrência \\
\hline $\begin{array}{c}\text { Discurso } \\
\text { indireto } \\
\text { quase textual }\end{array}$ & Sem Ocorrência \\
\hline $\begin{array}{l}\text { Modalização } \\
\text { seguida de } \\
\text { discurso } \\
\text { direto }\end{array}$ & Sem Ocorrência \\
\hline Modalização & $\begin{array}{l}\text { 1- Segundo a organização mundial da saúde (OMS), cerca de um } \\
\text { terço da população está infectada pelo agente causador da doença, o } \\
\text { Mycobacterium Tuberculosis. } \\
\text { 2- Os motivos, dizem os especialistas, são as altas concentrações } \\
\text { populacionais que facilitam a disseminação da doença através das } \\
\text { gotículas do espirro de pessoas contaminadas. } \\
\text { 3- Segundo a médica, os pacientes ao se sentirem melhor, } \\
\text { abandonam o tratamento e a doença se manifesta novamente, } \\
\text { infectando outras pessoas. } \\
\text { 4- Segundo Lopes Silva, isso permitiria uma aplicação imediata da } \\
\text { vacina e beneficiaria a enorme parcela da população infectada pelo } \\
\text { bacilo. }\end{array}$ \\
\hline Ilhas textuais & Sem Ocorrência \\
\hline
\end{tabular}


Para finalizar temos uma reportagem da Scientific American Brasil e uma da Ciência Hoje, ambas sobre vacinas, e por isso, com o número de DR menor se comparadas as que falam sobre clonagem humana.

A reportagem da Scientific tem 14 citações, verificamos que das reportagens analisadas, essa é a única em que o número de DI é maior que o de DD, são 6 DI e 5 DD. O número maior de DI revela que o enunciadorjornalista assume a responsabilidade pelos elementos expressivos, e pelas informações que são atribuídas ao especialista, o enunciador reformula com suas palavras o dizer do outro.

$\mathrm{Na}$ Ciência Hoje temos 8 citações, 4 DD e 4 modalizações. O uso do DD com seu sintagma introdutor e a parte citada, mostra que o enunciadorjornalista se exime de responsabilidade sobre o que está sendo dito.

\subsection{O DR nos artigos}

- Scientific American Brasil

\begin{tabular}{|c|l|}
\hline \multicolumn{2}{|c|}{ "Prós e contras da clonagem humana" jul/2003 } \\
\hline DR & \multicolumn{1}{|c|}{ Reprodução } \\
\hline $\begin{array}{c}\text { Discurso } \\
\text { Direto }\end{array}$ & Sem Ocorrência \\
\hline $\begin{array}{c}\text { Discurso } \\
\text { indireto } \\
\text { seguido de } \\
\text { discurso } \\
\text { direto }\end{array}$ & Sem Ocorrência \\
\hline $\begin{array}{c}\text { Discurso } \\
\text { Indireto }\end{array}$ & Sem Ocorrência \\
\hline $\begin{array}{c}\text { Modalização } \\
\text { seguida de } \\
\text { discurso } \\
\text { direto }\end{array}$ & Sem Ocorrência \\
\hline $\begin{array}{c}\text { Modalização } \\
\text { 1- O Anúncio do nascimento de Dolly, segundo o filósofo e bioeticista } \\
\text { italiano Maurizio Mori, assinalou o início de uma nova fase para a } \\
\text { bioética, a qual experimentou um salto qualitativo no sentido de } \\
\text { despertar a atenção pública mundial. }\end{array}$ \\
\hline $\begin{array}{c}\text { Ilhas textuais } \\
\text { Sem Ocorrência }\end{array}$ \\
\hline
\end{tabular}

"Como está o Brasil em relação à vacina" set/2002

\section{DR}

Reprodução 


\begin{tabular}{|c|l|}
\hline $\begin{array}{c}\text { Discurso } \\
\text { Direto }\end{array}$ & Sem Ocorrência \\
\hline $\begin{array}{c}\text { Discurso } \\
\text { indireto } \\
\text { seguido de } \\
\text { discurso } \\
\text { direto }\end{array}$ & Sem Ocorrência \\
\hline $\begin{array}{c}\text { Discurso } \\
\text { Indireto }\end{array}$ & Sem Ocorrência \\
\hline $\begin{array}{c}\text { Modalização } \\
\text { seguida de } \\
\text { discurso } \\
\text { direto }\end{array}$ & Sem Ocorrência \\
\hline Modalização & Sem Ocorrência \\
\hline $\begin{array}{c}\text { Ilhas textuais } \\
\text { 1- E fazemos isso toda vez que pedimos o chamado "teste para } \\
\text { aids", que utiliza a técnica de ELISA ou Werten Blot para verificar a } \\
\text { presença de anticorpos. }\end{array}$ \\
\hline
\end{tabular}

Nesses dois artigos da Scientific American Brasil, o discurso relatado é praticamente inexistente, encontramos apenas uma modalização no primeiro e uma ilha textual no segundo. Todo o texto tem uma estrutura argumentativa que tem respaldo apenas no conhecimento do enunciador, que não se vale de outras vozes para dar credibilidade e veracidade ao seu dizer.

Maingueneau (1997) esclarece que o Sujeito que enuncia a partir de um lugar definido não cita quem deseja, como deseja, em função dos seus objetivos conscientes, do público visado, etc. São as imposições ligadas ao gênero e a posição social do enunciador que regulam a presença ou ausência de citações.

- Ciência Hoje

\begin{tabular}{|c|l|}
\hline \multicolumn{2}{|c|}{ "A técnica de clonagem de mamíferos" out/2001 } \\
\hline DR & \multicolumn{1}{|c|}{ Reprodução } \\
\hline $\begin{array}{c}\text { Discurso } \\
\text { Direto }\end{array}$ & Sem Ocorrência \\
\hline $\begin{array}{c}\text { Discurso } \\
\text { indireto } \\
\text { seguido de } \\
\text { discurso } \\
\text { direto }\end{array}$ & $\begin{array}{l}1-\text { Em 1984, o biólogo norte-americano James McGrath e o } \\
\text { imunologista iugoslavo Davor Solter, por exemplo, chegaram a a } \\
\text { anunciar que os recursos técnicos da época estavam esgotados: "A } \\
\text { atividade diferencial dos genomas materno e paterno e os resultados } \\
\text { apresentados aqui sugerem que a clonagem de mamíferos através de }\end{array}$ \\
\hline
\end{tabular}




\begin{tabular}{|c|l|}
\hline $\begin{array}{c}\text { Discurso } \\
\text { Indireto }\end{array}$ & Sem Ocorrência \\
\hline $\begin{array}{c}\text { Modalização } \\
\text { seguida de } \\
\text { discurso } \\
\text { direto }\end{array}$ & Sem Ocorrência \\
\hline $\begin{array}{c}\text { Modalização } \\
\text { Sem Ocorrência }\end{array}$ & Semsferência nuclear é biologicamente impossível." \\
\hline $\begin{array}{c}\text { Ihas textuais } \\
\text { "uma colônia de organismos que, de modo assexuado (sem } \\
\text { intervenção de sexo), deriva de apenas um progenitor". }\end{array}$ \\
\hline
\end{tabular}

No artigo da Ciência Hoje, como podemos observar no quadro acima, o discurso relatado se estrutura de modo bem diferente do que ocorreu nas reportagens. Encontramos apenas uma ocorrência em DI seguido de DD, e uma Ilha textual, nenhuma em DD nem em Modalização, seja sozinha seja seguida de DD. Essa escassez de citações se deve ao fato de o autor enunciar do lugar mesmo da competência, de onde fala com a autoridade de especialista. Afinal ele é do Departamento de Bioquímica Médica da Universidade Federal do Rio de Janeiro. Seus argumentos são baseados nos conhecimentos especializados que possui, não necessitando de respaldo de outros especialistas, o enunciador é quem dá credibilidade ao texto e garante veracidade às informações. O discurso relatado, nesse caso, torna-se desnecessário na estruturação global do texto.

Com a análise do DR nas reportagens e artigos chegamos a algumas considerações:

Nas reportagens, de modo geral, o número de DR é expressivo, verificamos algumas variações em relação aos temas. Tema mais polêmico como "Clonagem Humana" exigiu um número maior de DR.

De acordo com Authier-Revuz (1998), o que o DR relata não é uma frase ou um enunciado e sim um ato enunciação, além disso, o DR não é restituição 
"completa", fiel de outro ato de enunciação que ele tenha como objeto. $\mathrm{Na}$ analise das reportagens observamos diferentes modos de relatar outra enunciação, chamamos a atenção para o DD e o DI.

O DD se mostrou presente em todas as reportagens demonstrando que as reportagens fazem grande uso desse tipo de discurso relatado. Usando o $\mathrm{DD}$, o enunciador se abstém de qualquer responsabilidade pelo que está sendo dito, além do mais, citar diretamente os especialista no assunto dá veracidade e credibilidade ao texto. O DI também esteve presente em praticamente todas as reportagens só que em menor número, se comparado ao DD. Esse tipo de discurso relatado, dá maior liberdade ao enunciador, pois este enuncia com suas próprias palavras as idéias do outro.

Nos artigos, o DR parece ser dispensável e é quase inexistente, o enunciador-especialista é detentor do conhecimento. Não há necessidade de outras vozes para dar credibilidade ao que diz. 


\section{CONSIDERAÇÕES FINAIS}

Chegamos ao final do nosso percurso. Estudando o funcionamento do discurso de divulgação científica em revistas especializadas observamos alguns fatores importantes na constituição dos efeitos de sentido dos enunciados.

Analisando as reportagens e os artigos, observamos que os gêneros são estruturados de acordo com o campo a que estão associados; notamos também que a estruturação tanto do discurso relatado quanto das relações enunciador/co-enunciador seguem a mesma orientação. Assim verificamos:

1. Os gêneros reportagem e artigo apresentam, de modo geral, algumas especificidades:

\begin{tabular}{|c|c|}
\hline REPORTAGEM & ARTIGO \\
\hline Informativo & Opinativo \\
\hline Enunciador/mediador: jornalista & Enunciador/mediador: especialista \\
\hline Fragmentado & Compacto \\
\hline Texto longo & Texto mais curto \\
\hline $\begin{array}{c}\text { Grande número de desenhos, fotos, } \\
\text { boxes, infográficos }\end{array}$ & Um ou outro infográfico \\
\hline Grande número de discurso relatado & Em número bem reduzido \\
\hline
\end{tabular}

Os textos apresentam certas coerções (enunciadores envolvidos, heterogeneidade, linguagem, organização textual) condicionadas pelo gênero associado a um contexto mais amplo, ou seja, ao campo.

As revistas Superinteressante, Galileu e Scientific American Brasil estão associadas ao campo do jornalismo comercial e, por isso, apresentam reportagens bastante fragmentadas com muitos desenhos, boxes, períodos mais curtos. Tudo isso tendo em vista tornar o texto mais atrativo ao seu destinatário. Aqui vale uma ressalva, a Scientific American tem um padrão diferenciado da Galileu e Superinteressante, inclusive há artigos assinados por cientistas. 
Já a reportagem da Pesquisa FAPESP, uma publicação da Fundação de Amparo a Pesquisa do Estado de São Paulo, apresenta características textual-discursivas (tais como, organização textual, abordagem temática, influência do campo jurídico etc.) diferentes das reportagens anteriores, uma vez que está ligada a outro campo, o científico.

A revista Ciência Hoje, de responsabilidade da SBPC, está inserida no campo científico que, por sua vez, orienta as coerções do gênero adotado. $O$ artigo publicado no periódico assume os moldes dos artigos científicos (resumo na primeira página, nome do autor e bibliografia).Pode-se inferir, recuperando os traços levantados, que esse é um exemplo de divulgação científica com leitores previamente representados com um certo nível de qualificação, o próprio suporte de divulgação, a revista Ciência Hoje, tem maior circulação no meio acadêmico, apesar de também ser comercializado em bancas de jornal. Além disso, estamos falando em artigo que possui coerções bem distintas das sofridas por uma reportagem. Um artigo é opinativo, nele há uma escassez de discurso relatado, temos também ausência de desenhos, boxes, fotos etc. $O$ texto não é fragmentado como na reportagem.

Nos artigos publicados na Scientific American Brasil, não temos o resumo e a bibliografia como no artigo anterior, mas o texto é igualmente opinativo, o especialista discute o tema apoiado no conhecimento científico que possui. Desse modo, verifica-se que a organização textual-discursiva dos textos de transmissão de saberes científicos sofre algumas coerções à medida que a divulgação científica acontece em um determinado gênero de discurso submetido a um determinado campo, isto é, a um tipo de discurso.

2. Nas reportagens da Superinteressante, Galileu e Scientific American Brasil, ligadas ao campo do jornalismo comercial, temos como enunciador um jornalista que procura prender a atenção de um co-enunciador leigo, com pouco conhecimento do assunto discutido, o objetivo parece ser o de tornar uma mercadoria interessante, uma leitura agradável e, por isso, vendável.

Daí o uso de uma cenografia envolvente, tendo a narrativa ficcional como moldura, e aproximativa, o diálogo direto com o leitor.

A outra reportagem é da revista Pesquisa Fapesp, o enunciador do texto é um jornalista, assim como nas anteriores. No entanto, a constituição dos 
sentidos entre o enunciador e o co-enunciador é diferente daqueles observados nas reportagens anteriores. Neste texto, não encontramos as tentativas de captação de um leitor seja através de esquemas, desenhos, fragmentação do texto para facilitar a leitura etc. $O$ enunciador escreve um texto bastante específico, informar ao leitor sobre o projeto de lei de Biossegurança. O público dessa reportagem é um leitor que busca informações específicas sobre política científica, podemos supor que esse co-enunciador (comunidade científica, políticos, público em geral interessado no tema) não é tão leigo quanto os das publicações anteriores. Essa mudança de tipo de leitor se deve ao fato de a revista Pesquisa FAPESP estar associada ao campo científico, ou seja, ela é produzida por uma fundação de amparo à ciência e tem maior circulação no meio acadêmico. A cenografia dessa reportagem, como já dita, é a de uma espécie de seminário, no qual são debatidas opiniões relativas a clonagem humana com fins terapêuticos.

O texto seguinte é um artigo publicado na Ciência Hoje. Nesse caso temos a seguinte cenografia: o enunciador desse artigo é um especialista em Bioquímica Médica, ou seja, é uma autoridade no tema tratado, que se dirige a um público misto, formado por leitores leigos e por leitores com algum conhecimento, pois usa léxico especializado, expõe os procedimentos laboratoriais do processo de clonagem. A revista é financiada pela mais importante sociedade científica do Brasil, a SBPC, por isso, além de divulgar o conhecimento ao público em geral, também se dirige a seus pares.

É o mesmo que ocorre com o artigo publicado na revista Scientific American Brasil na qual o texto vem assinado por um cientista, professor da UnB. Neste texto encontramos algumas passagens em primeira pessoa, o enunciador se insere nas discussões sobre a clonagem humana. Com as análises feitas verificamos que as relações que se estabelecem entre enunciador e co-enunciador sofre as coerções do gênero e do campo no qual é produzido e circula a revista em questão, as reportagens estabelecem suas cenografias de modo semelhante, temos sempre um jornalista-mediador que assume o papel de transmissor de um conhecimento que não é seu, que vem de outro lugar. Nos artigos o enunciador é detentor do saber, ele se dirige ao seu destinatário como conhecedor. O tema é debatido pelo próprio enunciador 
que dá a sua opinião sobre o caso e aconselha diretamente o leitor, por isso a inscrição de um leitor com certo conhecimento no tema discutido.

Cada discurso define o estatuto que o enunciador deve conferir-se e o que deve conferir a seu destinatário para legitimar o seu dizer. Observamos que as publicações são destinadas a públicos distintos, também são diferentes os enunciadores, as relações que se estabelecem entre enunciador e coenunciador são determinadas por coerções do gênero e do campo.

3. Nas reportagens da Superinteressante, Galileu, Pesquisa FAPESP, Scientific American Brasil e Ciência Hoje, o discurso relatado é bem presente. Ao citar especialistas no tema tratado, o enunciador garante a "verdade" e a relevância do assunto discutido. Encontramos nas reportagens um grande número de DD, sobre isso Maingueneau (2004a, p. 142) diz "a escolha do discurso direto como modo de discurso relatado geralmente está ligado ao gênero do discurso em questão ou às estratégias de cada texto. Em particular, pode-se procurar: criar autenticidade, distanciar-se, mostrar-se objetivo, sério."

Nos artigos da Ciência Hoje e Scientific American Brasil, o discurso relatado é bastante escasso, isso se deve, principalmente, às coerções do gênero "artigo" que pressupõe um enunciador que disserte, analise um fato. Nos textos analisados o enunciador avalia as conseqüências da clonagem humana, seu impacto na sociedade, etc. Ele assume a responsabilidade sobre o que está sendo dito, ele é a voz que dá autenticidade e credibilidade ao enunciado. Dessa maneira, no que diz respeito à divulgação científica, o discurso relatado se estrutura de acordo com o gênero do discurso considerado.

Por fim, a divulgação científica, entendida como uma prática discursiva que atravessa diferentes tipos de discursos/campos e conseqüentemente assume diferentes gêneros, tem seu funcionamento discursivo específico se associada a condições de produção específicas. 


\section{REFERÊNCIAS BIBLIOGRÁFICAS}

ADAM, J-M. Type de séquences textuelles élementaires. In Pratiques, n. 56, Metz, 1987.

. Cadre théorique d'une typologie séquentielle. In Études de linguistique appliquée. Paris: Didier Érudition, n. 83, p. 7-18, juil-sept. 1991

ALTHUSSER, L. Ideologia e aparelhos ideológicos de estado. (trad. de J. J. Moura Ramos) Lisboa, Presença-Martins Fontes, 1974.

AUTHIER, J. "Paroles tenues à distance". In: Matérialités discursives, Presses Universitaires de Lille, 1981.

AUTHIER-REVUZ, J. Heterogeneidade(s) enunciativa(s) . trad. Celene M. Cruz e João W. Geraldi. In: Cadernos de estudos lingüísticos, n919:25 -42 Campinas: Unicamp, 1990.

- Palavras incertas: as não-coincidências do dizer. 2 ed. Campinas: Unicamp, 2001.

AZEVEDO, F. As ciências no Brasil. V. 2, Rio de Janeiro: Editora da UFRJ, 1995.

BAKHTIN, M. Marxismo e filosofia da linguagem. trad. J.J M. Lahud e Y.F. Vieira São Paulo: Hucitec, 1979. Versão francesa. Original Russo: 1929.

. Estética da criação verbal. trad. Maria Ermantina G. G. Pereira São Paulo: Martins Fontes, 1992. Versão francesa. Original Russo: 1979.

BENVENISTE, E. Problemas de lingüística geral. 4. ed. trad. M. da G. Novak e M. L. Néri. Campinas: Pontes, 1995

O aparelho forma da enunciação In. Problemas de lingüística geral II. trad. Eduardo Guimarães et alii. Campinas: Pontes, 1989.

BOURDIEU, P. Os usos sociais da ciência: por uma sociologia clínica do campo científico. trad. Denice B. Catani. São Paulo: Editora UNESP, 2004. 
O campo científico. In: ORTIZ, R.(org.) Pierre Bourdieu: Sociologia. São Paulo, Ática, p. 122-155, 1983.

BRANDÃO, H. H. N. Introdução à análise do discurso. Campinas: Editora da UNICAMP, 1995.

BRANDÃO, H. H. N. "Texto, gêneros do discurso e ensino" In: Brandão. H. N. (Coord.) Gêneros do discurso na escola. São Paulo: Cortez, vol. 5, p. 17-45, 2000.

BRONCKART, J. P. et al. Le fonctionnement des discours. Paris: Delachaux \& Niestlé, 1985.

BRONCKART, J. P. Atividade de linguagem textos e discursos. Por um interacionismo sócio-discursivo. Trad. Anna Rachel Machado. São Paulo: educ, 2003.

BUENO, W. Jornalismo científico: conceito e funções. Ciência e Cultura. São Paulo, SBPC, vol. 37, n. 9, p. 1420-1427, set. 1985.

CHARAUDEAU, P. e MAINGUENEAU, D. Dicionário de análise do discurso. trad. Fabiana Komesu. São Paulo: Contexto, 2004.

FOUCAULT, M. Arqueologia do saber. trad. L.F. Baeta Neves. Petrópolis: Vozes, 1971.

GOLDSMITH, M. Popularização da ciência. Ciência e Cultura, São Paulo:SBPC, vol. 27, n. 6, p. 23-28, 1975.

GREGOLIN, M. R. Foucault e Pêcheux: na com strução da análise do discurso - diálogos \& duelos. São Carlos: Clara Luz, 2004.

GRILLO, S. V. de C. A produção do real em gêneros do jornal impresso. São Paulo: Associação Editorial Humanitas, 2004.

IVANISSEVICH, A. Ciência fora do casulo. In www.ciênciahoje.com.br n. 184, jul 2002.

JAKOBSON, R. Lingüística e poética. In Lingüística e comunicação.São Paulo, Cultrix, 1963. 
MAINGUENEAU. D. L'Analyse du discours. Paris: Hachette, 1991.

MAINGUENEAU, D. \& COSSUTTA, F. "L'Analyse des dicscours constituants" In: Langages no 117 p. 113-125, Paris: Larousse, 1995a.

MAINGUENEAU, D. "Présentation" In: Langages № 117 p. 05-11, Paris: Larousse, 1995b.

Novas tendências em análise do discurso. 3. ed. trad. Freda Indursky. Campinas, SP: Pontes, 1997.

. Termos-chave da análise do discurso. 1aㅡ reimpressão trad. Márcio V. Barbosa, Maria E. A T. Lima. Belo Horizonte: Ed. UFMG, 2000.

. O contexto da obra literária. São Paulo: Martins Fontes, 2001.

. Análise de textos de comunicação. 3. ed. trad. Cecília P. de Sousa-eSilva, Décio Rocha. São Paulo: Cortez, 2004a.

. Diversidade dos gêneros do discurso. In MACHADO, I.. L. \& MELLO, R. (orgs.) Gêneros: reflexões em análise do discurso. Belo Horizonte: NAD/FALE/UFMG, p. 43-57, 2004b.

MANUAL de redação: Folha de S. Paulo. 2 ed. São Paulo: Publifolha, 1987.

MOIRAND, S. L'explication. In: BEACCO J-C. (dir) L'astronomie dans les médias: analyses linguistiques de discours de vulgarisation. Paris: Sorbonne nouvelle, p. 141-167, 1999.

Formas discursivas da difusão de saberes na mídia. In: Rua: Revista do núcleo de desenvolvimento da criatividade da UNICAMP - NUDECRI. Campinas, n. 6, p. 9-24, mar. 2000.

MOREIRA, I. e MASSARANI, L. Aspectos históricos da divulgação científica no Brasil. In.: MASSARANI, L., MOREIRA, I.C., BRITO, F. (Orgs.) Ciência e Público: caminhos da divulgação científica no Brasil. Rio de Janeiro, Casa da Ciência/UFRJ, p. 43-64, 2002. 
ORLANDI, E. A linguagem e seu funcionamento. São Paulo: Brasiliense, 1984. 1986.

. "A análise do discurso: algumas observações". In DELTA, vol. 2, № 1,

. Divulgação científica e efeito leitor: uma política social urbana. In: GUIMARÃES, E. (Org.). Produção e circulação do conhecimento: estado, mídia, sociedade. Campinas: Pontes, p. 21-30, 2001.

PÊCHEUX, M. Semântica e discurso: uma crítica a afirmação do óbvio. trad. Eni Orlandi et alii. Campinas: Editora da Unicamp, 1988.

.Análise automática de discurso: três épocas (1983). In: GADET, F. \& HAK, T. (Orgs.) Por uma análise automática do discurso: uma introdução à obra de Michel Pêcheux. Campinas: Editora da UNICAMP, 1990.

POSSENTI, S. O 'eu' no discurso do 'outro' ou a subjetividade mostrada. ALFA, São Paulo, n. 39, p. 45-55, 1995.

REIS, J. A divulgação científica e o ensino. Ciência e Cultura, São Paulo, SBPC, vol. 16, n. 4, p. 352-353, 1964.

SILVA, T. D. Jornalismo e divulgação científica. In: Rua: Revista do núcleo de desenvolvimento da criatividade da UNICAMP - NUDECRI. Campinas, n. 8, p. 129-146, 2002.

VOGT, C. Ciência, divulgação e leitura. Pesquisa FAPESP, São Paulo, FAPESP, nำ100, p.60, Jun/2004.

ZAMBONI, Lílian M. S. Cientistas, jornalistas e a divulgação científica: subjetividade e heterogeneidade no discurso da divulgação científica. Campinas: Autores Associados, 2001.

Corpus de análise

COSTA, V. R. Vacina genética contra tuberculose. Ciência Hoje. São Paulo, SBPC, vol. 26, no. 154, p. 46-47, out. 1999.

DIEGUEZ, F. A um passo da clonagem humana. Galileu. São Paulo:Globo, out. 2001. 
EZZELL, C. AIDS: a grande batalha da vacina. Scientific American Brasil. São Paulo: Duetto, p. 28-34 set. 2002.

FIORAVANTI, C. O alvo é a saúde humana. Pesquisa FAPESP, São Paulo: FAPESP, no. 81, p. 36-43, nov. 2002.

GARCIA, R. AIDS: imunes por natureza. Galileu. São Paulo:Globo, set. 2003.

GARRAFA, V. Prós e contra da clonagem humana. Scientific Amrecian Brasil. São Paulo, Duetto, p.56-57, jul. 2003.

IZIQUE, C. Lei polêmica: projeto restringe poder da CTNBio, proíbe clonagem terapêutica e mobiliza cientistas. Pesquisa FAPESP, São Paulo: FAPESP, no. 97, p. 16-21, mar. 2004.

KALLÁS, E. G. Como está o Brasil em relação à vacina. Scientific American Brasil. São Paulo: Duetto, p. 35, set. 2002.

RUMJANEK, F. D. A técnica de clonagem de mamíferos. Ciência Hoje, São Paulo: SBPC, vol. 30, no. 176, p. 34-38, out. 2001.

VOMERO, M. F. Homens em série. Superinteressante, São Paulo:Abril, p.6367, jul. 2001.

ZOCHIO, M Vacinas fazem bem ou mal?. Superinteressante, São Paulo: Abril, p.41-46, fev. 2001. 